\title{
Seasonality and dynamics of the semi-deciduous transition forests of the Araguaia floodplain, Brazil
}

\author{
Dissertation \\ zur Erlangung des Doktorgrades \\ der Fakultät für Agrarwissenschaften \\ der Georg-August-Universität Göttingen
}

vorgelegt von

Dariusz Kurzątkowski

Geboren in Warschau

Göttingen, June 2017 
Referent: Prof. Dr. Christoph Leuchner Korreferent: Prof. Dr Johannes Isselstein Tag der mündlichen Prüfung: 09.05.2017 


\section{To my parents and family,}

for their continuous love and support 


\section{Abstract}

Araguaia floodplain is the large floodplain area in the Neotropics located in the transition zone of Amazon forest and cerrado. The region is characterized by seasonal flooding and pronounced dry seasons. We recorded all trees $(\mathrm{DBH}>5 \mathrm{~cm})$ in 30 permanent plots $(50 \mathrm{~m} \mathrm{x}$ $50 \mathrm{~m}$ ) located at different topographic positions across a flooding gradient. We examined the influence of flooding from low to high terrain on floristic composition, forest structure and aboveground live biomass and compared changes in the structural pools and variations in the processes of growth, mortality and recruitment over a five year period. We measured net photosynthesis in four tree species during the three main stages:aquatic phase, terrestrial dry phase and terrestrial wet phase. Tree species richness was relatively low with 14-31 species per plot and was not affected by flood level, but tree species composition and family importance values differed markedly between annually flooded (AF) and non-annually flooded (NAF) forest stands. Forest top canopy height wasnegatively correlated with flood level $\left(\mathrm{R}^{2}=0.25, \mathrm{p}=0.002\right)$. Mean wood specific gravity (WSG) of the plots increased with the flood level $\left(\mathrm{R}^{2}=0.43, \mathrm{p}<0.001\right)$ and apparently was unrelated to drought intensity. Stem density (plot mean $1040 \mathrm{ha}^{-1}$ ), mean dbh, tree basal area $\left(19.4 \mathrm{~m}^{2} \mathrm{ha}^{-1}\right.$ ) and AGB (116.8 Mg $\mathrm{ha}^{-1}$ ) were not dependent on flood level. The cumulative basal area in the plots increased by $0.84( \pm 0.45) \mathrm{m}^{2} \mathrm{ha}^{-1} \mathrm{yr}^{-1}$ (mean $\pm \mathrm{SD}$ ) in the AF plots in lower terrain and by $0.69( \pm 1.0) \mathrm{m}^{2} \mathrm{ha}^{-}$ ${ }^{1} \mathrm{yr}^{-1}$ in the NAF plots, corresponding to an aboveground biomass increase of $0.81( \pm 0.57)$ and $0.69( \pm 1.58)$ Mgha $^{-1} \mathrm{yr}^{-1}$ in the AF and NAF plots. Mean diameter growth rate was 1.8 $( \pm 0.44) \mathrm{mm} \mathrm{yr}^{-1}$ in the AF and $2.0( \pm 0.56) \mathrm{mm} \mathrm{yr}^{-1}$ in the NAF plots (corresponding to a coarse wood production of $1.53( \pm 1.29)$ and $\left.2.02( \pm 0.52) \mathrm{Mg} \mathrm{ha}^{-1} \mathrm{yr}^{-1}\right)$, indicating no flooding effect on radial growth. Mean mortality rates were $1.9( \pm 0.37) \% \mathrm{yr}^{-1}$ in the AF plots and $1.8 \%( \pm 0.87) \% \mathrm{yr}^{-1}$ in the NAF plots with no differences along the flooding gradient. We observed the highest reduction in photosynthetic activity during the aquatic phase, when the soil was saturated with water. We conclude that these drought-affected tropical floodplain forests have a lower standing biomass and aboveground productivity than central Amazonian floodplain forests in more humid climates, and the imprint of the flooding gradient on stand dynamics is relatively weak, which may result from the lower flooding height and the interaction of flooding with low nutrient supply and periodic drought. 


\section{Contents}

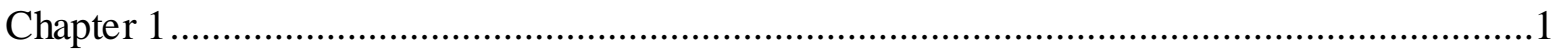

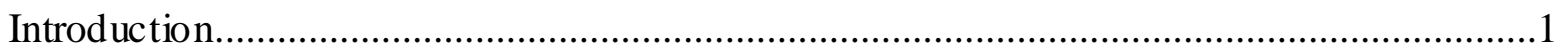

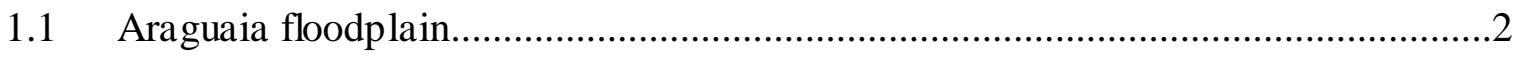

1.2 Amazon floodplain forest................................................................................

1.3 Biomass and carbon in the tropical forest...............................................................

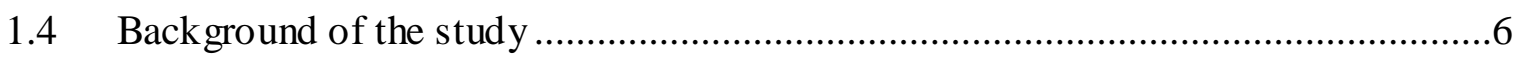

1.4.1 The Bananal Island Carbon Sequestration Project ..............................................

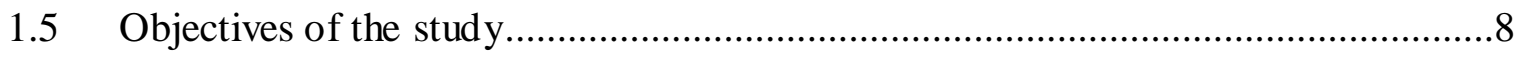

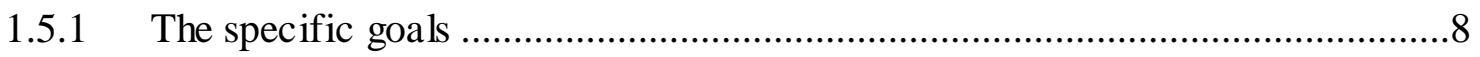

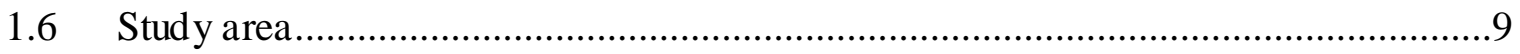

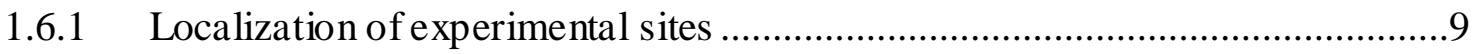

1.6.2 Description of study sites ........................................................................10

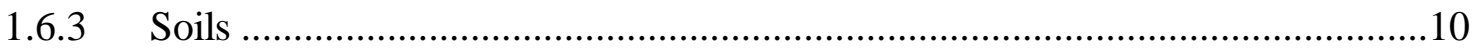

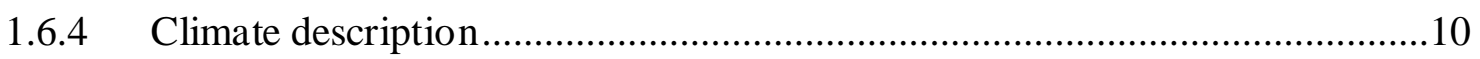

1.6.5 Forest inventory design............................................................................11

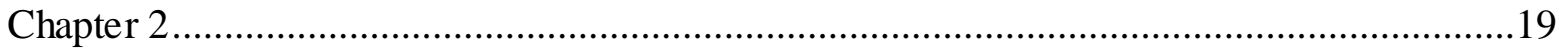

Effects of flooding on trees in the semi-deciduous transition forests of the Araguaia

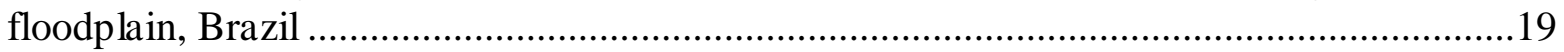

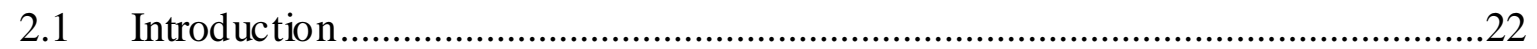

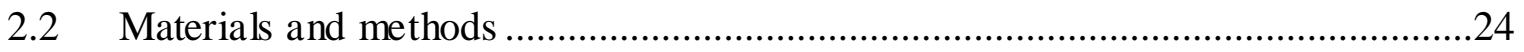

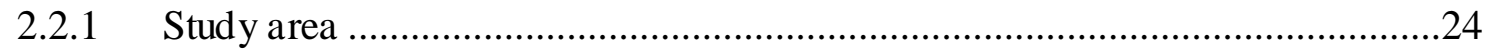

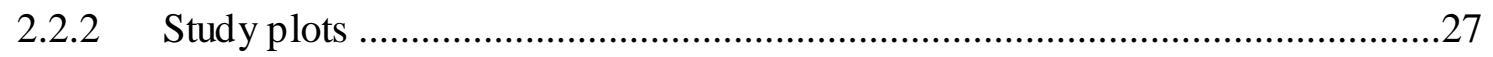

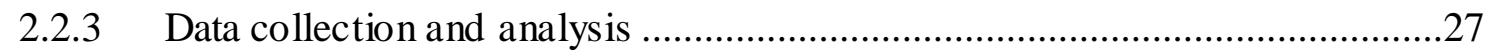

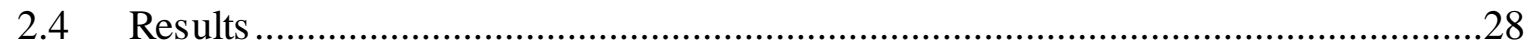

2.4.1 Variation in flood level height and flood duration at the study site .................28

2.4.2 Variation in forest structure, aboveground biomass and species composition.29

2.4.3 Relationships between species abundance and flood level height.....................35

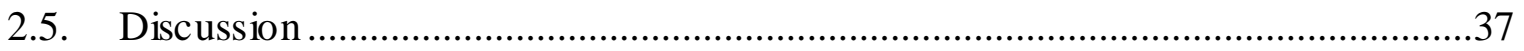

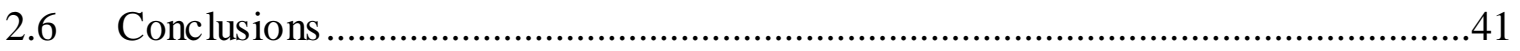

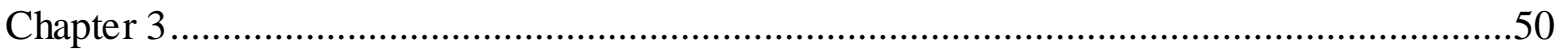

Stand dynamics of the drought-affected floodplain forests of Araguaia River, Brazilian

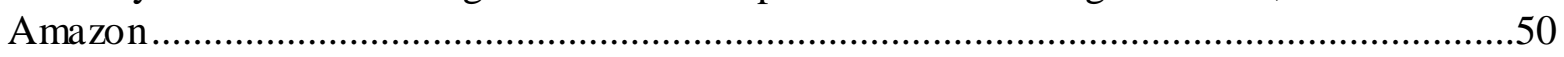

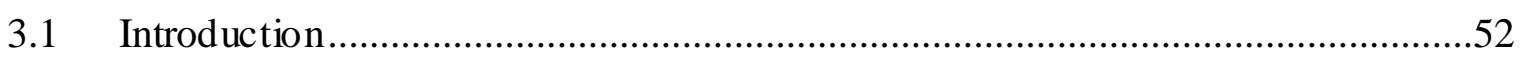

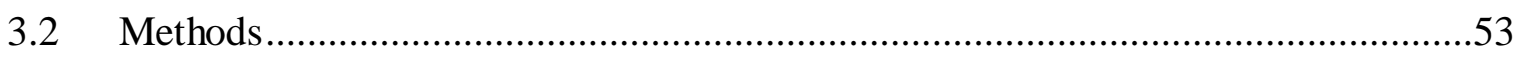




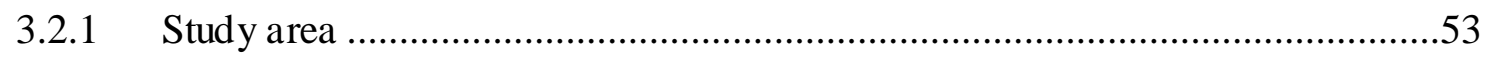

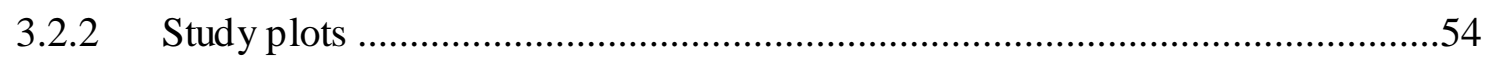

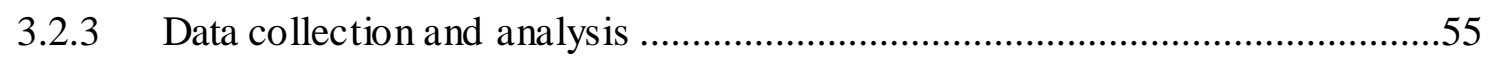

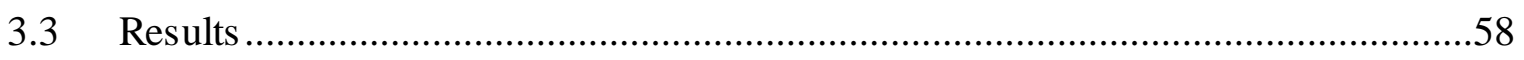

3.3.1 Forest structure, coarse wood production and forest dynamics.........................58

3.3.2 Population dynamics of selected species.............................................................62

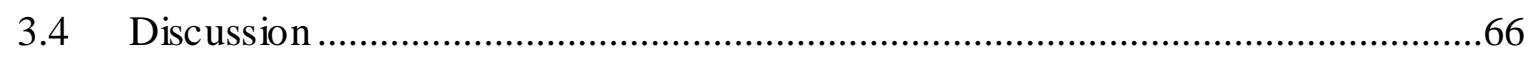

3.4.1 Stand dynamics (recruitment and mortality) ...................................................68

3.4.2 Tree species differences in growth and mortality ...........................................69

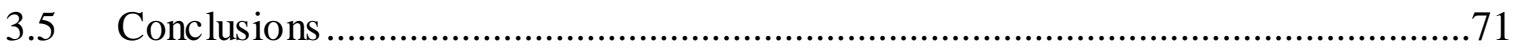

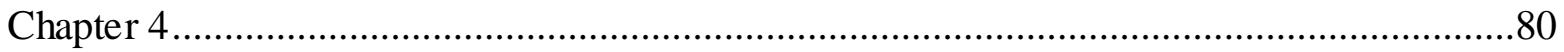

Variation of photosynthetic activity in the drought-affected floodplain forests of Araguaia

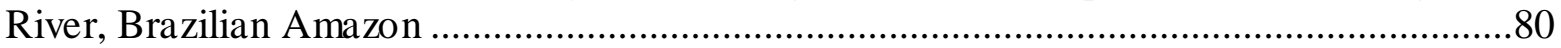

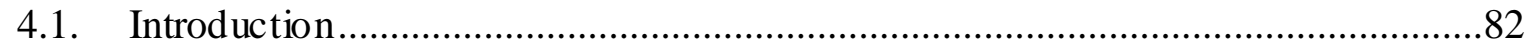

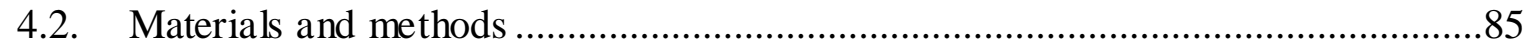

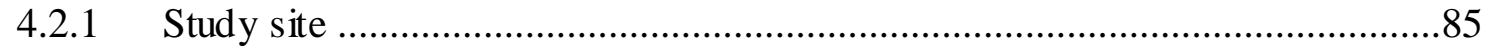

4.2.2 Species descriptions ...................................................................................86

4.2.3 Gas-exchange measurements ...........................................................................87

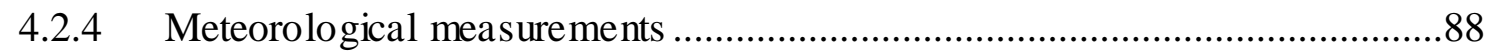

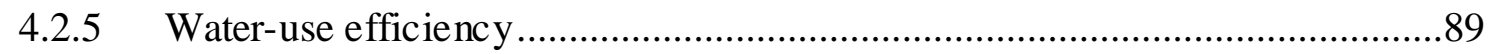

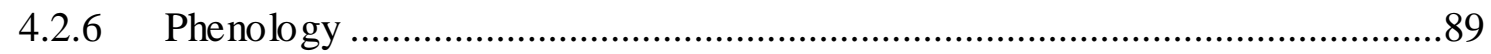

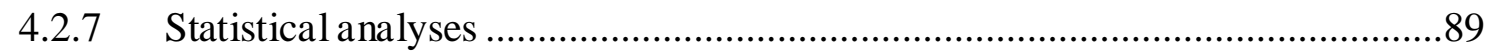

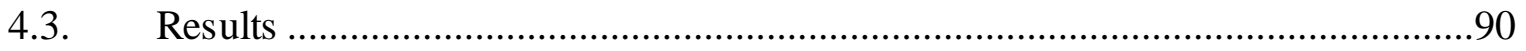

4.3.1 Climate and environmental condition...........................................................90

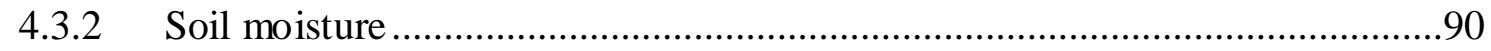

4.3.3 Changes in photosynthetic active radiation ......................................................92

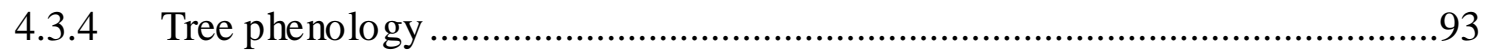

4.3.5 Inter- seasonal variability in gas exchange ........................................................

4.3.6 Diurnal patterns of photosynthetic activity......................................................97

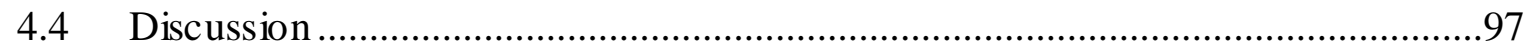

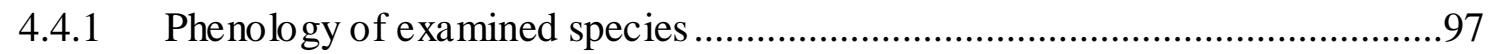

4.4.2 Photosynthetic activity during aquatic phase ....................................................98

4.4.3 Photosynthetic activity during a terrestrial dry phase.......................................100

4.4.4 Photosynthetic activity during a terrestrial wet phase .....................................102

4.4.5 Diurnal reduction of photosynthetic activity ……............................................102 


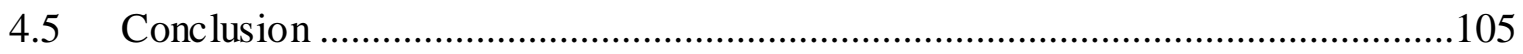

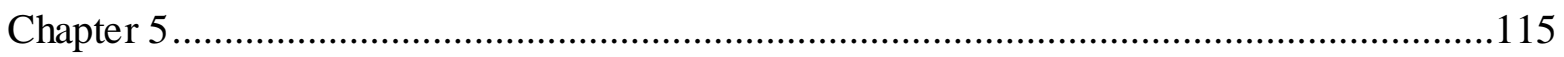

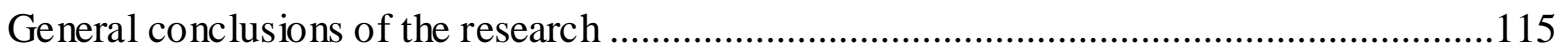

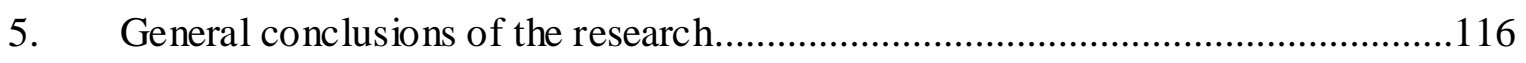


Chapter 1

\section{Introduction}




\subsection{Araguaia floodplain}

The tropical forest of Araguaia floodplain is located in the southeastern part of the Amazon along the Araguaia River in central Brazil. The transition between Amazon forest and cerrado vegetationoccurs in this area. Two strong annual environmental disturbances - the inundation and the dry period, have caused the formation of a forest with a particular dynamic.

The Araguaia floodplain is the fifth biggest floodplain in South America, with a total area of $59000 \mathrm{~km}^{2}$. In this area, the flood varies by about $5 \mathrm{~m}$ over the seasonal cycle, but most of the floodplain is inundated to only 1-2 m depth or even less (Eiten 1985). The flooding that occurs in the forest is predicable and monomodal. The flood pattern favors the development of trees adaptation. The floodplain areas are formed by abandoned meanders or by the filling of depressions with water from flooding river. This is due to the annual inundation lasting four to five months (mostly from January to May), when the forest floor gets saturated with water.

Araguaia is a clear water river, similar to rivers with catchments in the ancient shields of Goiania in Central Brazil like Tocantins, Xingu or Tapajos. The water is transparent and has a green hue. These rivers have low amounts of sediments and dissolved solids. The larger parts of the rivers have a $\mathrm{pH}$ of 5 to 6 . The floodplains of clear water rivers are of intermediate fertility.

The large part of the Araguaia floodplain area includes Bananal Island (Hamilton et al. 2002), and the area upriver of the island to $15^{\circ} \mathrm{S}$ latitude. Bananal Island is the largest fluvial island in the world and is about $350 \mathrm{~km}$ long and $55 \mathrm{~km}$ wide with total area of $19162 \mathrm{~km}^{2}$; it is the most representative region (Eiten, 1985) for floodplain vegetation. The island is formed by the Araguaia River and an arm of it, the Javaes River. Bananal Island is largely floodplain vegetation (Eiten, 1985), while the surrounding uplands tend to be covered by tropical moist forest to the north and west, and savanna (the majority of which has been converted to agriculture) to the south and east. These include gallery forests and a plant community type of seasonally inundated forest, regionally known as "Ipuca" (Eiten, 1985). 
The Araguaia floodplain is well known for its large numbers of aquatic birds, caimans, mammals and fishes. Due to the diverse vegetation, this area is classified as an ecotone and is protected as a National Park of Araguaia, Carajás Indian Reserve, and State Park Cantão. However, the region is currently under land use pressure, called ' the arc of deforestation'. Human impact centers mainly upon cattle farming and fire use to improve the pasture, followed by soya and rice plantation. In the future, the plans for construction of hydrologic power plants could affect the hydrology in a large area on the Araguaia River.

However, this type of floodplain forest has so far received much less attention than the impressive floodplain forest ecosystems of central Amazonia. Situated at the margin of the Amazon, the Araguaia River floodplain is in need of further funding and research in order to understand its potential for carbon storage and carbon sequestration abilities. Further, the biodiversity and ecology of these unique ecosystems in the transition zone of tropical moist to dry forest is poorly understood.This would improve our understanding of the carbon balance of the Amazon basin (Schimel, 1995; Houghton et al. 2000; Ketterings et al. 2001).

\subsection{Amazon floodplain forest}

Floodplains are defined as areas that are periodically inundated by the lateral overflow of rivers or lakes and/or by direct precipitation or groundwater. The cyclical inundation, changing the physicochemical environment (Junk et al. 1989), contributes significantly to its biodiversity (Gopal et al. 2000).

20-25\% of the Amazon surface is permanently flooded (Junk, 2006; Melak \& Hess, 2010). The majority of central Amazonian wetlands are forested(Schöngart et al.2010; Wittmann et al. 2010; Wittmann, 2013). The floodplain systems present the significant temporal variation of physical, chemical and biological factors. According to the 'flood pulses' theory described by Junk et al. (1989), inundation is the main force in floodplain systems. It controls the production patterns, affects primary and secondary production, influences decomposition and nutrient cycles in water and soil. Flooding may have either positive or negative effect on plant growth depending on the timing, duration and hydrologic energy of the flood events. The highest rates of production occur within periodic floods of short 
duration due to the subsiding of nutrients and water, while stagnant flooding of long duration causes physiological stress and results in lower production.

Due to the kinetic energy of flowing water, flooding by rivers can result in sedimentation and erosion. Flowing river water transports more suspended and dissolved substances into and out of- the floodplain than the flowing rainwater. The nutrient status of river floodplains is higher and more dynamic than of areas flooded by rainwater.

Tree species quantities are numerous, but the ecology of these wetlands has been poorly studied (Wantzen et al. 2006). Trees in the flooded forest are, in general, shorter than those in terra firme forest (Campbell et al. 1986). The basal area of the várzea forest type may be considerably higher than the terra firme forest (Worbes 1983).

Establishment of seedlings is the most critical phase of forest regeneration in floodplains. New growth seedlings often are destroyed during the next flood. As a consequence, the forest floor in regularly inundated wetlands usually contains very low numbers of seedlings and young trees (Worbes, 1983). The regeneration in seasonal inundation forests is limited, and occurs only in particularly favorable years with short or low flooding.

Leaf litter fall in flooded forests has been little studied (Adis et al. 1979; Franken et al. 1979). The seasonal várzea forest is deciduous, while the igapó counterpart is evergreen. Peak leaf fall occurs during the flood period. The leaf fall is interpreted as an adaptation of the trees to flooding. The trees' ability to survive a flood period of about 300 days in the same region is poorly understood. Furch (1984) relates that their chlorophyll-a to chlorophyl-b ratio is low, favoring light absorption at low light intensity. Maintaining functional leaves while flooded is advantageous, since photosynthesis can begin soon after inundation.

Many tree species growing in seasonally flooded Amazonian wetland show distinct annual growth rings, with growth being correlated with the extent of the dry period (Worbes, 1984, 1985, 1986; Worbes \& Leuschner, 1987). 


\subsection{Biomass and carbon in the tropical forest}

More than $50 \%$ of the carbon in the Amazonian rainforest is in the form of woody biomass: tree trunks, branches and large roots (Brown et al. 1995; Keller et al. 2001). Tropical rainforests play an important role in the global terrestrial carbon cycle (Dixon et al. 1994), accounting for 32 to $36 \%$ of terrestrial net primary production (NPP) (Field et al. 1998; Melillo et al. 1993; Potter et al. 1993). The Amazon region represents half of the rainforests in the world and contains approximately $40 \%$ of the carbon stock in terrestrial biomass (Philips et al. 1998). The change in the quantity of biomass of the Amazon forest has a significant impact on regional and global climates. It is estimated that $50 \%$ of the biomass is composed of carbon, and during burning deforestation or other forms of destruction around two-thirds of the carbon is incorporated into the biosphere in the form of carbon dioxide. $\mathrm{CO}_{2}$ is considered one of the main factors causing the Greenhouse Effect. The total annual emission of $\mathrm{CO}_{2}$ from the Amazon, as a result of land use change, is between 150 and 200 megatons of carbon (Houghton et al. 2000). The carbon source from clearing South American tropical forests is equivalent to $5-10 \%$ of the fossil fuel emissions in the 1990s (Achard et al. 2004).

Previous research estimated that the quantity of biomass in the Amazon rainforest varies between 155 and 352 tons per hectare (Brown et al. 1995). More recent research carried out by Fearnside (1997) shows a greater value of biomass stock. He found 464 ton-ha- 1 in areas of primary forest, and Houghton et al. (2000) estimated that the value was between 290 and 464 ton $\mathrm{ha}^{-1}$. Keller et al. (2001) estimated that the biomass stock was between 222 and 270 ton ha- 1 in the Tapajós National Forest. The average total biomass of the Amazon forest is estimated to be 327 ton ha $^{-1}$ (Fearnside, 1994).

In the last ten years there is accumulating proof that old growth tropical forest accelerates in growth (Lewis et al. 2004), recruitment and mortality (Philips \& Gentry 1994; Philips et al. 2004) and an increase in biomass (Malhi \& Grace, 2000; Backer et al. 2004).But there is little understanding of the constraints and determinants of current forest biomass. This is why quantifying the amount of carbon stored and cycled in the tropical forest is important. 
The role of tropical forests draws attention, and the data produced are used in developing models for carbon content and flux (Brown \& Lugo, 1984, Brown, 1997). Understanding the mechanisms that link environmental variability and vegetation productivity is particularly important to constrain projections of Earth system feedbacks under future climate (KeppelAleks et al. 2014; Boisier et al. 2015). Relatively small changes in the structure of the forests could have global consequences for biodiversity, the carbon cycle and climate change. Seasonal and inter-annual variability in vegetation productivity has profound impacts on the global carbon cycle (Poulter et al. 2014; Zhang et al. 2014; Keppel-Aleks et al. 2014; Gatti et al. 2014; Schimel et al. 2015; Cleveland et al. 2015).

\subsection{Background of the study}

This research is located in the Tocantins state. The new state was created in 1988, from the northern territory of the existing state of Goiás. Formation of the new state had the context to the development of this region in Brazil.

In the year 1988, about 1650 square $\mathrm{km}$ was deforested in the Tocantins state.For the formulation of environmental policies, the quantifying of biomass and carbon stock in this region was of great importance.There is a lack of data about the biomass stock in this transitional area between the Amazon forest and the cerrado.

The most important studies on Tocantins vegetation are by Rizzo (1981), Radambrasil (1981), Ratter (1987) and Mileski (1994). Available publications and herbarium collections have revealed that very little is known about this region.

The research presented here started in September 2001 as part of "Bananal Island Carbon Sequestration Project”, and was funded by the "AES Barry Foundation” from Wales. After two years, the project was incorporated into the "Large-Scale Biosphere Atmosphere Experiment in Amazonia” (LBA Project), which was an international research initiative led by Brazil. During the LBA project, in September 2003, a 42 meters high Carbon Flux Tower was build and new research areas in the adjacencies of the tower were established. 


\subsubsection{The Bananal Island Carbon Sequestration Project}

The Bananal Island Carbon Sequestration Project was Brazil's first large-scale carbon sequestration pilot project, conducted in the period between 1998-2003. In this project Ecológica, an NGO from Palmas, Brazil was responsible for project design and implementation. The carbon sequestration objectives were achieved through forest conservation and regeneration, and by agro-forestry schemes in communities in the Bananal Island region.

Sapling nurseries have been set up in partnership with local councils and community organizations to support the agro-forestry schemes producing fruit, timber and medicinal species for distribution to local inhabitants and for reforestation.

The project's research component was carried out principally by the Canguçu Research Centre, which was opened in August 1999. The Canguçu Research Centre is the emerging center for climate change and renewable energy issues in the Amazon Region and was participating in the Large Biosphere-Atmosphere Project of Amazonia (LBA). Work at Canguçu is conducted in partnership with the Federal University of Tocantins (UFT) and with national and international research institutions including the Institute of Astronomy, Geophysics and Atmospheric Sciences at the University of São Paulo (IAG/USP), the Tocantins State University (UNITINS), the Palmas campus of the Lutheran University of Brazil, and the New Hampshire University in USA. 


\subsection{Objectives of the study}

The goals of this research are to examine the seasonal patterns of natural disturbance and influence of structure, biomass stock, and forest growth and forest dynamics in the two areas with different flood levels in the Araguaia floodplain forests.

\subsubsection{The specific goals}

The specific goals for this work are:

a. Identify the species and families in the Araguaia floodplain forest

b. Examine the variability of floristic composition and forest structure

c. Quantify the live aboveground coarse woody biomass

d. Determine changes in stand-level processes of growth, recruitment and mortality in forest in the period of five years

f. Investigate the phenology and photosynthetic activity of four trees species during the aquatic, terrestrial dry and terrestrial wet phase to determine the stress factors.

g. Determine the flood level, ground-water level and changes in soil moisture during the study period. 


\subsection{Study area}

\subsubsection{Localization of experimental sites}

The experimental site was located in the Reserve of Cantão Park of Tocantins State, in the southeastern Brazilian Amazon (Fig 1).

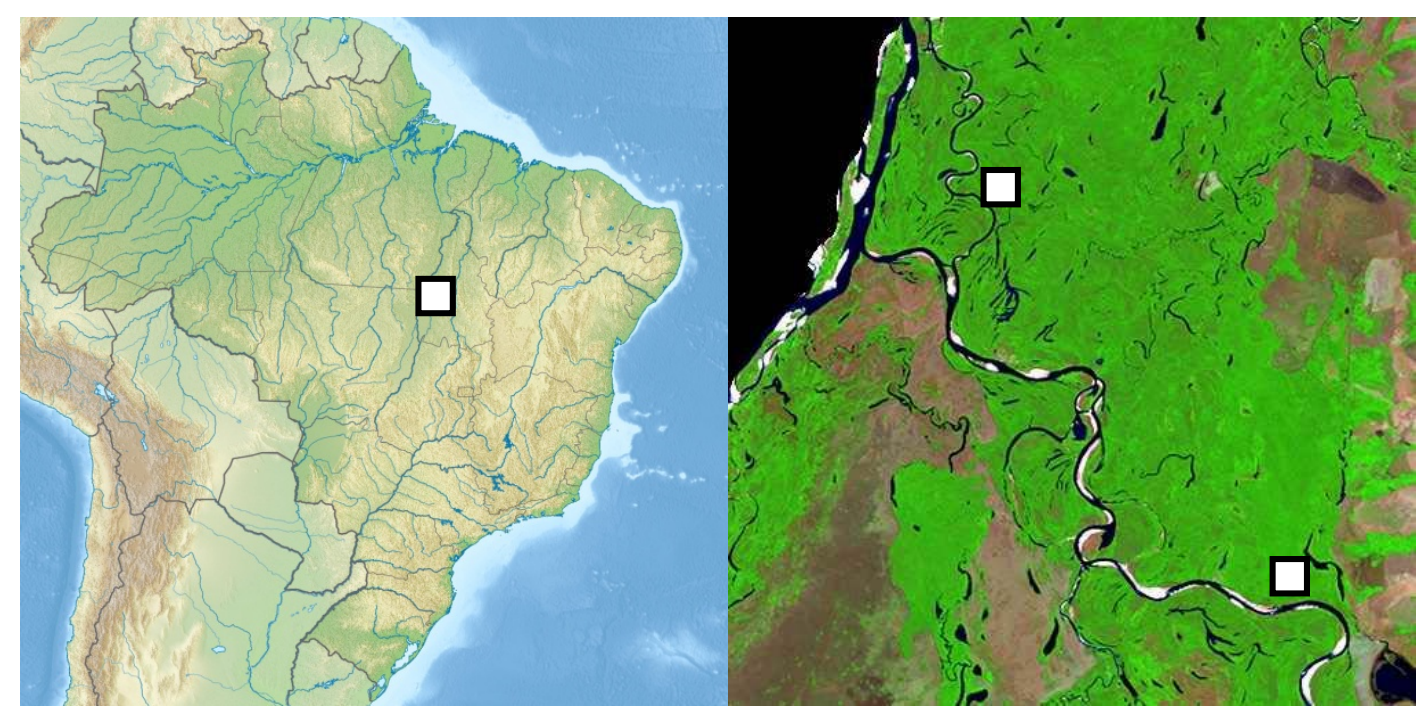

(A)

(B)

Figure 1. (A) Localization of the research areas in Brazil, (B) in the Reserve of Cantão Park. The Javaezinho study site is located in the north and the Canguçu study site is located in the south.

The Reserve of Cantão Park belongs to Araguaia River floodplain, covers 89.000 ha and is located in the transition zone between two Brazilian dominants biomes: the Amazon forest in the west and cerrado in the east. Also, the Bananal Island (Eiten, 1985), the largest river island in the world, belongs to this area. The Bananal Island is formed by the Araguaia and Javaés Rivers, and is located in the south- west from the study site.

The study region is classified by the Brazilian Institute of Geography and Statistics (IBGE), as an ecotone, a transition area between adjacent ecological communities (ecosystems). The study area is located at $180 \mathrm{~m}$ elevation. The forest is affected by annual floods, with water levels to $5 \mathrm{~m}$ above the surface for periods up to 5 months, from January to June. 


\subsubsection{Description of study sites}

The investigation for the current work was carried out on two experimental sites: Canguçu Research Center and Javaezinho. The Canguçu Research Center, with the geographic coordinates of $9^{\circ} 58^{\prime} 41^{\prime \prime} S$ and $50^{\circ} 02^{\prime} 12^{\prime \prime} \mathrm{W}$, is located on the east side of the Javaés River. This Research Center was established and financed by the Carbon Sequestration Project on the Bananal Island.

The study site at Javaezinho (geographic coordinates of $9^{\circ} 49^{\prime} 16^{\prime \prime} \mathrm{S}$ and $50^{\circ} 08^{\prime} 55^{\prime \prime} \mathrm{W}$ ) was founded by the Institute of Astronomy, Geophysics and Atmospheric Sciences at the University of São Paulo, as part of the LBA project (Large Scale Biosphere-Atmosphere Experiment in Amazonia). Javaezinho site is located $40 \mathrm{~km}$ north from Canguçu Research Center, $2 \mathrm{~km}$ east from Javaezinho River, which is a tributary of the Javaés River. The study transect was localized on the foot print of the "Bananal Carbon Flux Tower".

\subsubsection{Soils}

Soils at both study sites ranged from upland red-yellow and yellow oxisols and red-yellow ultisols, to alluvial soils with hydromorphic lateritic and gley characteristics (DNPM, 1978).

\subsubsection{Climate description}

The climate of this region is hot and semi-humid. The average annual precipitation is 1552 mm (Fig. 2). The rainy period ranges from November to April.The dry season is three months, without any or very low precipitation, and ranges from June to September. The average annual temperature is $26^{\circ} \mathrm{C}$, the maximum temperatures of $30^{\circ} \mathrm{C}$ occurring during the months of August and September. The average monthly minimum temperature of $22{ }^{\circ} \mathrm{C}$ occurs in July. The relative humidity of the air varies from $80 \%$ in the rainy and $60 \%$ in the dry period. 


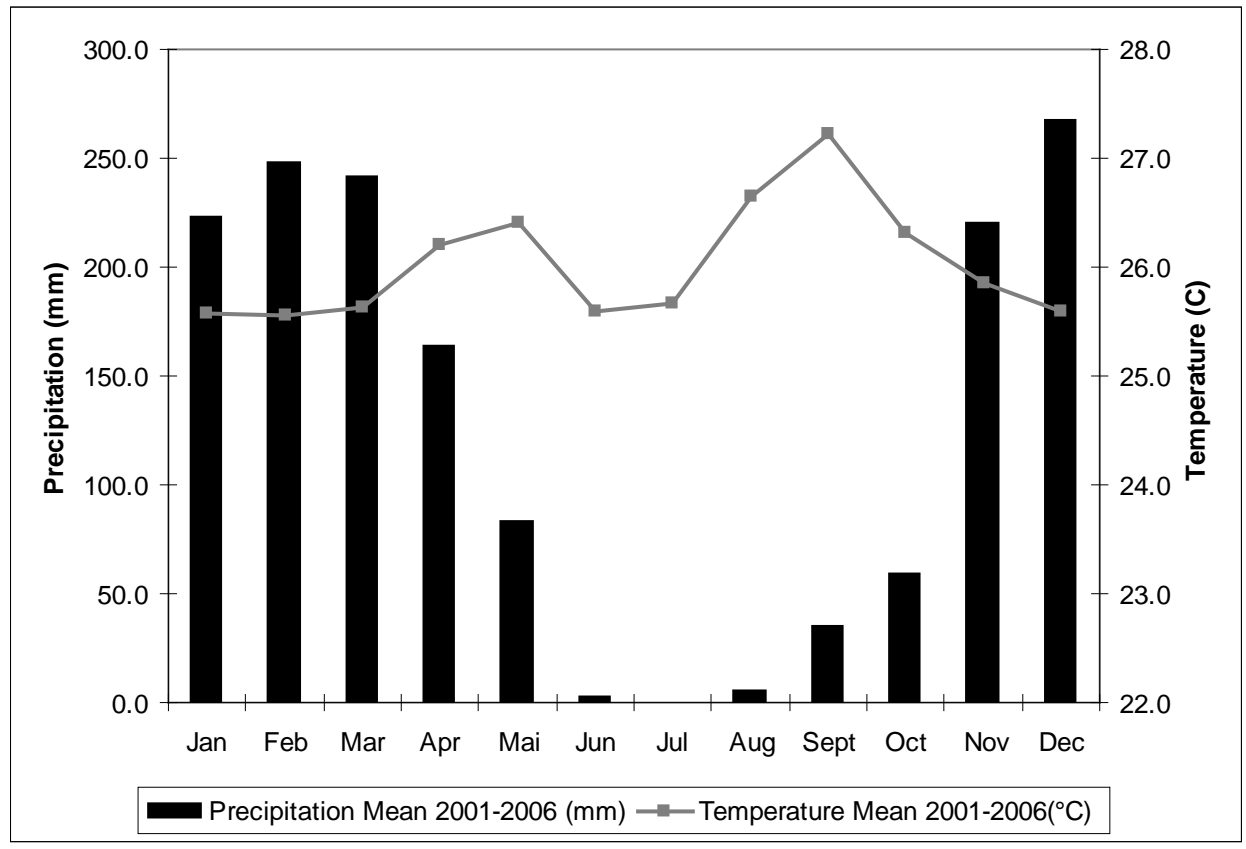

Figure 2. Monthly mean temperature $\left({ }^{\circ} \mathrm{C}\right)$ and precipitation $(\mathrm{mm})$ observed $2001-2006$ at the meteorological station located at the Canguçu Research Center in Cantão State Park, Tocantins State, Brazil.

\subsubsection{Forest inventory design}

In the experimental site, Canguçu Research Center (CRC), three transects were established with the total length of $4.5 \mathrm{~km}$. In April 2001, 30 plots, with a size of 50 x $50 \mathrm{~m}$ were randomly selected on both sides of the transects, covering an area of 7.5 hectares. During an inundation period, the highest flood level on the plots was monitored. On the basis of this information, the forest in the study plots was divided into two groups: 1) Not annually flooded forest (NAF) and 2) Annual flood forest (AF).

Trees with DBH (Diameter at Breast Height) greater than $5 \mathrm{~cm}$ were included in the inventory. All the trees included in the inventory were numbered and identifies by species and family name. The identification of tree species was done locally with the help of a native knowledgeable in the subject. Some botanical samples were identified by comparing materials to herbarium collections located at the Federal University of Tocantins, and confirmed by bibliographic research (Lorenzi, 2002). The measurements of DBH were taken 
with a fiberglass tape. All trees with $\mathrm{DBH}$ greater than $5 \mathrm{~cm}$ were tagged and recorded. Diameters for buttressed trees were measured immediately above the buttresses to avoid overestimation (Condit, 1998).

Measurements of the heights of the trees were taken using a pole telescope with a maximum length of $15 \mathrm{~m}$. Height for trees taller than $15 \mathrm{~m}$ were visually estimated. The ground positions of the trees in the plot were recorded and mapped to make the trees easier to find for a second measurement. The trees were re-measured after a period of 5 years, during a dry season in 2006. 


\section{References}

Achard F., Eva H.D., Mayaux P. 2004. Improved estimates of net carbon emissions from land cover change in the tropics for the 1990s. Global Biogeochemical Cycles, 18: art. no. GB2008.

Adis J., Furch K. and Irmler U. 1979. Litter production of a Central Amazonian black waterinundation forest. Tropical Ecology20:236-245.

Backer T., R., Phillips O., L., Malhi Y. 2004. Increasing biomass in Amazonian forest plots. Philosophical Transactions of the Royal Society of London Series B- Biological Sciences, 359, 353-365.

Boisier, J. P., Ciais, P., Ducharne, A., and Guimberteau, M. 2015: Projected strengthening of Amazonian dry season by constrained climate model simulations, Nature Climate Change, 5,656-660.

Brown, S. 1997 Estimating Biomass and Biomass Change of Tropical Forests. FAO, Rome.

Brown, S. and A. E. Lugo, 1984.Biomass of tropical forests: A new estimate based on forest volumes. Science 223:1290-1293.

Brown I.F., Martinelli L.A., Wayt Thomas W., Moreira M.Z., Cid Ferreira C.A., Victoria R.L. 1995. Uncertainty in the biomass of Amazonian forest: an example from Rondônia, Brazil. For Ecol Manage 75:175-189.

Campbell, D., G., Dally D., C., Prance, G., T., Maciel, U., N., 1986: Quantitative ecological inventory of terra firme and varzea tropical forest on the Rio Xingu, Brasilian Amazon.

Chave J, Condit R, Aguilar S, Hernandez A, Lao S, Perez R. 2004. Error propagation and scaling for tropical forest biomass estimates. Philosophical Transactions of the Royal Society of London B359: 409-420.

Cleveland, C. C., Taylor, P., Chadwick, K. D., Dahlin, K., Doughty, C. E., Malhi, Y., Smith, W. K., Sullivan, B. W., Wieder, W. R., and Townsend, A. R. 2015: A comparison of plotbased satellite and earth system model estimates of tropical forest net primary production, Global Biogeochem. Cy., 29, 626-644. 
Dixon R. K, Brown S, Houghton RA, Solomon AM, Trexler MC, Wisniewski J (1994) Carbon pools and flux of global forest ecosystems. Science 263:185-190.

Eiten, G. 1985. Vegetation near Santa Teresinha, NE Mato Grosso. Acta Amazônica, v.15, n.3/4, p.275-301, 1985.

Fearnside, P.M. 1997. Serviços ambientais como estratégia para o desenvolvimento sustentável na Amazônia rural. p. 314-344 In:C. Cavalcanti (ed.) MeioAmbiente, DesenvolvimentoSustentável e PolíticasPúblicas.São Paulo, SP: Editora Cortez. 436 pp. Fearnside, M., 1994. Biomassa das florestas amazonicas brasileiras, In: Seminario Emissao x Sequestro de CO2: uma nova oportunidade de negocios para o Brasil. Porto Alegre. Anais. Companhia Vale do Rio Doce, Rio de Janeiro, , pp.95-124.

Franken, M., Irmler U. and Klinge, H. 1979: Litterfall in inundation, riverine and terra firmeforests of Central Amazonia. Tropical Ecology20:225-235.

Furch, B. 1984. Untersuchungen zur Überschwemmungstoleranz von Baurnen der Várzea und des Igapó: Blattpigmente. Biogeographica19:77-83

Gatti, L. V., Gloor, M., Miller, J. B., Doughty, C. E., Malhi, Y., Domingues, L. G., Basso, L. S., Martinewski, A., Correia, C. S. C., Borges, V. F., Freitas, S., Braz, R., Anderson, L. O., Rocha, H., Grace, J., Phillips, O. L., and Lloyd, J. 2014.: Drought sensitivity of Amazonian carbon balance revealed by atmospheric measurements, Nature, 506, 76-80.

Gopal, B., Junk, W.J., Davis, J.A.,2000. Biodiversity in Wetlands: Assessment, Function and Conservation, Volume 1. Backhuys Publishers: Leiden, The Netherlands.

Hamilton, S. K., S. J. Sippel\& J. M. Melack. 2002. Comparison of inundation patterns among major South American floodplains. Journal of Geophysical Research, 107: LBA 5$1 / 14$.

Houghton R.A, Skole D.L, Nobre C.A, Hackler J.L, Lawrence K.T, Chomentowski W.H (2000) Annual fluxes of carbon from deforestation and regrowth on the Brazilian Amazon. Nature 403:301-304. 
Houghton, R. A., K. T. Lawrence, J. L. Hackler, and S. Brown. 2001. The spatial distribution of forest biomass in the Brazilian Amazon: a comparison of estimates. Global Change Biology 7: 731-746.

Junk, W. J. 1989: Flood tolerance and tree distribution in Central Amazonian floodplains. Pp. 47-64 in Nielsen, L. B., Nielsen, I. C. \& Baisley, H. (eds). Tropical forests: botanical dynamics, speciation and diversity. Academic Press, London.

Junk, W. J., C. Nunes da Cunha, K. M. Wantzen, P. Petermann, C. Strüssmann, M. Marques, and J. Adis. 2006. Biodiversity and its conservation in the Pantanal of Mato Grosso, Brazil. Aquatic Sciences 68(3):278-309.

Keller M, Palace M, Hurtt G. 2001. Biomass estimation in the Tapajós national forest, Brazil - examination of sampling and allometric uncertainties. Forest Ecology and Management154: 371-382.

Keppel-Aleks, G., Wolf, A. S., Mu, M., Doney, S. C., Morton, D. C., Kasibhatla, P. S., Miller, J. B., 25 Dlugokencky, E. J., and Randerson, J. T. 2014: Separating the influence of temperature, drought,and fire on interannual variability in atmospheric CO2, Global Biogeochem. Сy., 28, 1295-1310.

Ketterings, Q.M., Coe, R., Noordwijk, M., van Ambagau, Y., Palm, C.A., 2001. Reducing uncertainty in the use of allometric biomass equations for predicting above-ground tree biomass in mixed secondary forests. For Ecol Manage 146, 199-209.

Klinge, H., Junk, W.J., Revilla, C.J. 1990: Status and distribution of forested wetlands in tropical South America, For. Ecol. Manage., 33/34 (1990), pp. 81-101.

Lewis S., L., Malhi Y, Phillips O., L., 2004: Fingerprinting the impacts of global change on tropical forest. Philosophical Transactions of the Royal Society of London Series BBiological Sciences, 359, 439-462.

Lorenzi, H., 2002. Arvoresbrasileiras manual de identificacao e cultivo de plantasarboreas do Brasil. 2. ed. Nova Odessa: Instituto Plantarum, 2002. v. 2368 p.

Malhi Y., Grace J (2000) Tropical forests and atmospheric carbon dioxide. Trends in Ecology and Evolution, 15, 332-337. 
Melack, J.M. \& Hess, L.L. 2010. Remote sensing of the distribution and extent of wetlands in the Amazon basin. In: Junk, W.J., Piedade, M.T.F., Wittmann, F., Schöngart, J. \& Parolin, P. (eds.) Central Amazonian floodplain forests: ecophysiology, biodiversity and sustainable management, pp. 43-59. Springer, Berlin, DE.

Melillo J.M, McGuire A.D, Kicklighter D.W, Moore B, Vorosmarty C.J, Schloss A.L, 1993. Global climate-change and terrestrial net primary production. Nature 363:234-240.

Mileski, E. 1994.Aspecto da vegetação e do ecossistema da Itha do Bananal: mapa fitoecológica e indicadores da pressãoantrópica. Brasilia: Gráfica da Secretária de Assuntos Estratégicos, 104 p.

Phillips, O. L., Malhi, Y., Higuchi, N., Laurance, W. F., Núñez, P. V., Vásquez, R. M., Laurance,S. G., Ferreira, L. V., Stern, M., Brown, S., and Grace, J. 1998. Changes in the carbon balance of tropical forests: Evidence from long-term plots,Science282, 439-442. Philips O., L., Backer T., R., Arroyo L. 2004. Patern and process in Amazon tree turnover, 1976-2001. Philosophical Transactions of the Royal Society of London Series B- Biological Sciences, 359, 381-407.

Philips O., L., Gentry A., H. 1994. Increasing turnover trough time in Tropical Forest. Science, 263, 954-958.

Potter C.S, Randerson J, Field C, Matson P Vitousek P.M, Mooney H.A, Klooster S. 1993. Terrestrial ecosystem production: a process model based on global satellite and surface data. Global Biogeochem Cycles 7:811-841.

Poulter, B., Frank, D., Ciais, P., Myneni, R. B., Andela, N., B, J., Broquet, G., Canadell, J. G., Chevallier, F., Liu, Y. Y., Running, S. W., Sitch, S., and van der Werf, G. R. 2014. Contribution of semi-arid ecosystems to interannual variability of the global carbon cycle, Nature, 509, 600-603.

RADAMBRASIL 1981.Tocantins:levantamento de recursosnaturais. Rio de Janeiro: Ministério das Minas e Energia.

Ratter J. A (1987): Notes on the vegetation of the Parque Nacional do Araguaia (Brazil). Notes Royal Botanic Garden, v.44, n.2, p.311-342. 
Rizzo J. A., 1981.Flora do Estado de Goiás:plano de coleção. Goiânia: Universidade Federal de Goiás, 35p.

Schimel, D.S. 1995.Terrestrial ecossystems and carbon cycle.Glob Change Biol 1, 77-91

Schimel, D., Pavlick, R., Fisher, J. B., Asner, G. P., Saatchi, S., Townsend, P., Miller, C., Frankenberg, C., Hibbard, K., and Cox, P. 2015: Observing terrestrial ecosystems and the carbon cycle from space, Glob. Change Biol, 21, 1762-1776.

Schöngart, J.,Wittmann, F., Worbes, M. 2010. Biomass and net primary production of Central Amazonian floodplain forests. InAmazonian Floodplain Forests: Ecophysiology, Biodiversity and Sustainable Management, Junk WJ, Piedade MTF, Wittmann F, Schöngart J, Parolin P (eds). Ecological Studies 210, Springer Verlag:Berlin/ Heidelberg/New York; 347-388.

Wantzen, K.M., Sá, M.F.P., Siqueira, A., Nunes da Cunha, C. 2006. Stream-valley systems of the Brazilian cerrado: impact assessment and conservation scheme. Aquatic Conservation16, 713-732.

Wittmann, F., Schöngart, J., Junk, W.J.2010. Phytogeography, species diversity, community structure and dynamics of central Amazonian floodplain forests. In Amazonian Floodplain Forests: Ecophysiology, Biodiversity and Sustainable Management, Junk W., J., Piedade M., T., F., Wittmann F.,SchöngartJ.,Parolin P. (eds). Ecological Studies 210, Springer Verlag: Berlin/Heidelberg/New York; 61-102.

Wittmann, F., Householder, E., Piedade, M.T.F., De Assis, R.L., Schöngart, J., Parolin, P., Junk, W.J.2013.Habitat specifity, endemism and the neotropical distribution of Amazonian white-water floodplain trees.Ecography 36, 690-707.

Worbes, M. 1983. Vegetationskundliche Untersuchungen zweier berschwemmungswälder in Zentralamazonien — vorläufige Ergebnisse, Amazoniana8 (1983), pp. 47-65.

Worbes, M. 1984. Periodische Zuwachszonen an Bäumen zentralamazonischer Überschwemmungs wälder, Naturwissenschaften 71 (1984), p. 157.

Worbes, M., 1985. Structural and other adaptations to long-term flooding by trees in Central Amazonia, Amazoniana 9 (1985), pp. 459-484. 
Worbes, M., 1986. Lebensbedingungen und Holzwachstum in zentralamazonischen Überschwemmungswäldern, Scr. Geobot. 17 (1986), pp. 5-112.

Worbes \& Leuschner, 1987. Annual rings of trees from Central Amazonian inundation forests, Proc. Int. Symp.New York (1987), pp. 272-280.

Zhang, Y., Guanter, L., Berry, J. A., Joiner, J., van der Tol, C., Huete, A., Gitelson, A., Voigt, M., and Köhler, P. 2014. Estimation of vegetation photosynthetic capacity from space-based measurements of chlorophyll fluorescence for terrestrial biosphere models, Glob. Change Biol., 20, 3727-3742. 


\section{Chapter 2}

\section{Effects of flooding on trees in the semi- deciduous transition forests of the}

\section{Araguaia floodplain, Brazil}

Dariusz Kurzatkowski, Christoph Leuschner \& Jürgen Homeier

Acta Oecologica 69 (2015), Pages 21-30 


\begin{abstract}
The Araguaia floodplain,one of the large floodplain areas in the Neotropics, is located in the transition zone of Amazon forestsand and cerrado. The region is characterized by annual floodingsand a pronounced dry season of three months. We examined the influence of flooding from low to high terrain on floristic composition, forest structure and aboveground live biomass (AGB). We recorded all trees $(\mathrm{dbh}>5 \mathrm{~cm})$ in 30 permanent plots $(50 \times 50 \mathrm{~m})$ located at different topographic positions across a flooding gradient.
\end{abstract}

Sixty-ninetree species from 30 plant families were recorded; Fabaceae(15 species) was the most abundant family, followed by Myrtaceae (5), Anacardiaceae (4) and Rubiaceae(4). Family composition was similar to Central Amazonian floodplain forests and many widely distributed flood-tolerant tree species were shared. Tree species richness was relatively low with 14-31 tree species per plot and was not affected by flood level, but tree species composition and family importance values differed markedly between annually flooded and non-annually flooded forest stands.

Forest top canopy height varied between 10.5 and $18.5 \mathrm{~m}$ and wasnegatively correlated with flood level $\left(\mathrm{R}^{2}=0.25, \mathrm{p}=0.002\right)$. Mean wood specific gravity (WSG) of the plots increased with the flood level $\left(\mathrm{R}^{2}=0.43, \mathrm{p}<0.001\right)$ and apparently was unrelated to drought intensity. Stem density (plot mean $1040 \mathrm{ha}^{-1}$ ), mean dbh, tree basal area (19.4 $\mathrm{m}^{2} \mathrm{ha}^{-1}$ ) and AGB (116.8 $\mathrm{Mg} \mathrm{ha}^{-1}$ ) were not dependent on flood level. The low AGB compared to Central Amazonian floodplain forests is probably a result of the pronounced dry season and limited nutrient availability in the igapó forests of the Araguaia floodplain. In view of the predicted increase of extended drought periods with global warming, we assume that future forests in the study area may lose some or all drought-sensitive tree species and likely may face a reduction in AGB. 


\section{Highlights}

- We studied tree composition and biomass (AGB) of the Araguaia floodplain, Brazil.

- The region is characterized by annual floodings and a pronounced dry season.

- Forest canopy height decreased and mean wood density increased with flood level.

- Species richness, basal area and AGB of trees were not dependent on flood level.

- The low AGB of the studied forest is most likely a result of the strong dry season in combination with limited nutrient availability.

Keywords: AGB, Amazon, drought, flood level, tree species diversity, wood specific gravity 


\subsection{Introduction}

Tropical floodplain forests are unique ecosystems which harbor a wealth of plant and animal species with specific adaptations to seasonal flooding and anoxia (Junk, 1989). Freshwater floodplains cover an area of approximately 1.7 million square kilometers within the Amazon basin and include seasonally inundated forests, riparian zones, swamps, and bogs (Junk et al. 2011).With an extension of approximately $550000 \mathrm{~km}^{2}$, large-river floodplains fringing the Amazon River and its major tributaries account for approximately 7-8\% of the Amazon basin (Melack and Hess 2010).Most research on these systems has been conducted in the Central Amazonian várzea and igapó forests in a tropical humid climate. However, floodplain forests are also present at the margins of the humid tropical realm in the transition zone to tropical semi-arid climates.

Seasonal flooding contributes significantly to biodiversity (Gopal et al. 2000) and affects plant communities in many aspects. The structure, floristic composition and tree species richness of inundation forests are tightly linked to their position in the flood-level gradient (Junk, 1989; Ayres, 1993), but also depend on sediment characteristics determined by the dynamic geomorphology of the river system. Seasonal inundation and associated anoxia often result in reduced metabolic activity, inhibition of photosynthesis and growth depressions of the trees (Worbes, 1985; Joly, 1994; Parolin 2001; Herrera, 2013). In certain species, inundation triggers the formation of hypertrophic lenticels on the stem bark, of extended aerenchyma in the roots and other anatomical and morphologic adaptations to oxygen deficiency (Kozlowski, 1984; Junk 1996; Piedade et al. 2000; Parolin et al. 2002).

Some of the tree species of the várzea and igapó forests are widespread particularly in semideciduous forests and savannas of the Neotropis (Prance, 1979). Junk (1989) and Worbes (1997) assume that those widespread species do not possess primary adaptations to flooding, but generally are tolerant to seasonal impairment of growing conditions. Ter Steege et al. (2003) and Witmann et al. (2006a) observed that the inundated Amazon forest is characterized by a trend of decreasing tree species diversity from the West to the East. Apart from this gradient, tree diversity generally decreases with the length of the flooding period due to the selective pressure imposed on the trees to adapt to this extreme habitat (Junk, 1989; Ferreira, 1991; Wittmann et al. 2006a). In savanna areas, plants have to deal with 
alternating periods of flooding and water limitation (Parolin et al 2010), and the severe drought stress that often characterizes the terrestrial phase favors a mixture of savanna vegetation and forested patches (Lourival et al. 2011; Nunes da Cunha and Junk, 2011).

The Araguaia floodplain forest is the fifth largest floodplain area in South America with a total area of $59.000 \mathrm{~km}^{2}$. It is located at the south-eastern fringe of the Amazon forest in the transition zone between tropical moist and tropical dry forest (cerrado) with a pronounced dry period of four to five months. Araguaia River is a clear water river and the floodplain vegetation could be classified as clear water igapó (Junk et al. 2011). The majority of central Amazonian wetlands are forested(Schöngart et al; Wittmann et al.; Wittmann, 2013).While the immediate study region is covered by large tracts of natural forest vegetation wellpreserved in Cantão State Park, the greater Araguaia floodplain is part of the so-called 'Arc of deforestation' in southern Amazonia which is under heavy pressure by human expansion.

The floodplain forests are usually exposed to several months of flooding followed by a period with marked soil desiccation. Combined measurements of evapotranspiration and soil hydrology in the study area have shown that the groundwater table is closely linked to the river water level and that the vegetation is sensitive to extended drought periods (Borma et al. 2009). So it can be assumed that more elevated stands should be stronger affected by drought during the dry season.

In the semi-arid floodplain forests of the Araguaia floodplain and elsewhere, trees have to cope with long periods of flooding and with seasonal drought as well. Thus, tree growth is hampered by two main stressors in the course of a year, but as reported by Parolin (2010) and Parolin et al. (2010), many of the adaptations to survive flooding (e.g., sclerophyllous leaves) are also beneficial under drought stress. We expect that the standing biomass of these drought-affected floodplain forests is smaller than in the várzea and igapó forests of the humid Amazon. However, this type of floodplain forest has so far received much less attention than the impressive floodplain forest ecosystems of central Amazonia. This is unsatisfactory because knowing the carbon stores and $\mathrm{C}$ sequestration of this type of floodplain forest at the margin of the Amazon would improve our understanding of the carbon balance of the Amazon basin (Schimel1995; Houghton et al. 2000; Ketterings et 
al.2001). Further, the biodiversity and ecology of these unique ecosystems in the transition zone of tropical moist to dry forest is only poorly understood.

This study examines the variability of floristic composition and forest structure and estimates the aboveground coarse woody biomass (AGB) in 30 plots located at different topographic positions in a tropical floodplain forest (Araguaia system) at the south-eastern fringe of the Amazon which is exposed to a marked dry season. We predicted that tree species composition changes with increasing maximum height of inundation level from a community composed of drought-adapted, flooding-sensitive tree species at highest terrain to a flooding-tolerant, drought-sensitive assemblage close to the river. Due to the existence of two opposing stress gradients from low to high terrain, we further assumed that AGB in this forest is generally lower than in the moist floodplain forests of the Central Amazon. We expected AGB to show a hump-shaped distribution along the elevation gradient with

biomass peaking at sites with only low to moderate water levels during inundation where stress due to both anoxia and drought is probably lowest.

Since tree species richness is negatively affected by height and duration of flooding in Amazonian inundation forests (e.g., Wittmann et al. 2006a), we further predicted that $\alpha$ diversity declines from higher to lower terrain with increasing maximum flood level height. Our study also delivers basic information on the structure and species composition of a poorly studied tropical forest type that is under pressure not only through deforestation but also by recent climate warming with extended drought periods at the margins of the Amazon basin (e.g. Olivares et al. 2015).

\subsection{Materials and methods}

\subsubsection{Study area}

The study area is located in the southern part of Cantão State Park in Tocantins State in the south-eastern Brazilian Amazon (Fig. 1). The study region is part of the transition area between the Amazon forest in the west and cerrado vegetation in the east (Brazilian Institute 
of Geography and Statistic, IBGE). Cantão State Park belongs to the Araguaia river floodplain (Eiten 1985) and is covered by large areas of intact moist forest and patches of cerrado on drier soil.
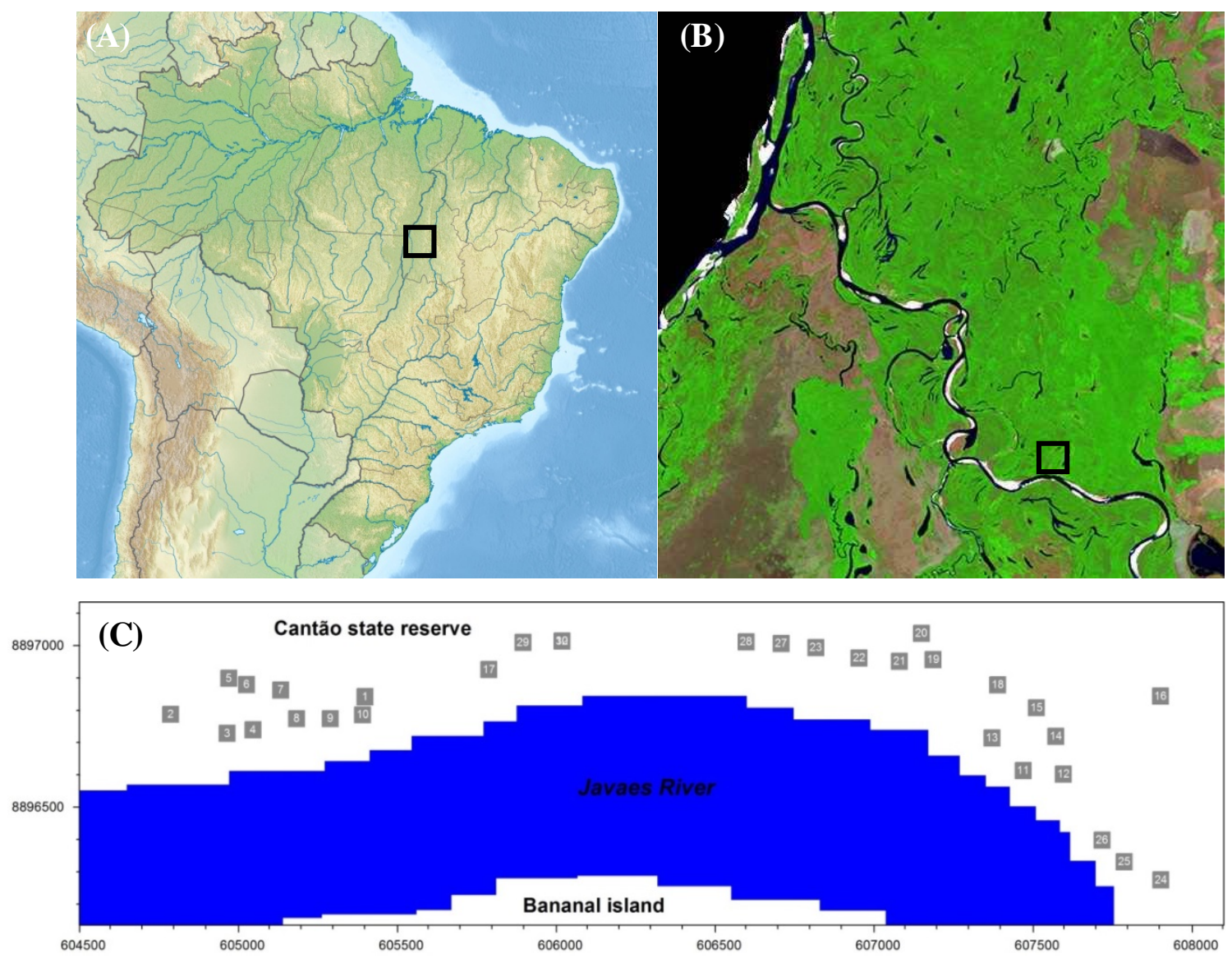

Figure 1.(A,B) Location of the study area in Brazil (BrasilVisto do Espaço, http:/www.cdbrasil.cnpm.embrapa.br) and (C) the distribution of plots along the Javaes river in the Cantão State Reserve, Tocantins, Brazil.

The soils of the study sites are quite variable ranging from upland red-yellow and yellow Oxisols and red-yellow Ultisols to alluvial soils with hydromorphic lateritic and gleyic characteristics (DNPM, 1978). The soils on the floodplain are acid and nutrient-poor Dystrophic Plinthosols and Gleysols (Martins 2006). 
The climate of the region is hot and semi-humid (Fig. 2) with an average annual precipitation of $1552 \mathrm{~mm}$. The rainy period lasts from November to April, followed by a distinct dry season from June to September with monthly precipitation of $50 \mathrm{~mm}$ or less. The average annual temperature is $26^{\circ} \mathrm{C}$, the highest mean monthly temperature is $30^{\circ} \mathrm{C}$ in August and September, while the lowest mean monthly temperature is $22{ }^{\circ} \mathrm{C}$ in July. Relative air humidity varies between $80 \%$ in the rainy and $60 \%$ in the dry season.

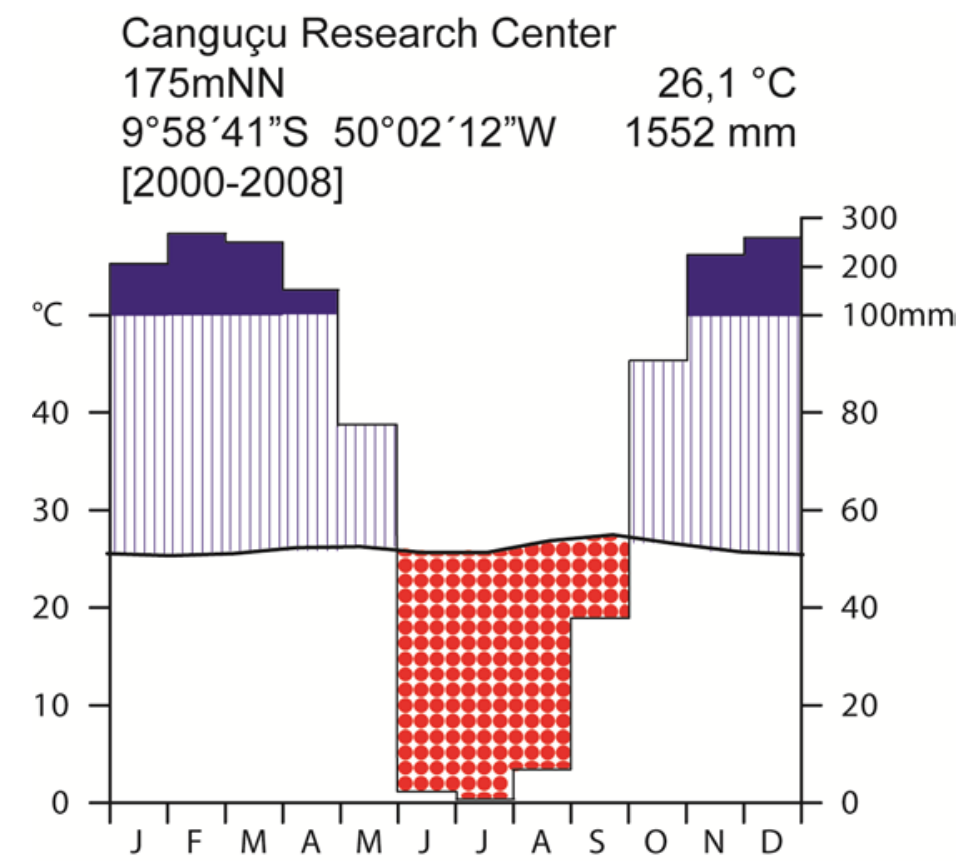

Figure 2.Climate diagram of the Canguçu Research Center in Cantão State Reserve, Tocantins State, Brazil. 


\subsubsection{Study plots}

The study plots are located on the right bank of Javaés River within an area of $10 \mathrm{~km}^{2}$; the distance to the Canguçu Research Center (CRC; 958'41'S, 5002'12’W) is 0.2 to $5 \mathrm{~km}$. We established 30 plots with a size of $50 \times 50 \mathrm{~m}(0.25 \mathrm{ha})$ in order to study changes in forest vegetation in relation to variation in flood level height. For plot selection, we avoided canopy gaps and early successional stages. The distance of the plots to Javaés River varied between 0.1 and $1.5 \mathrm{~km}$. The 30 study plots cover a total forest area of 7.5 ha. The maximum flood level in a plot was defined as the distance from the soil surface to the upper limit of the dark water mark visible on the trees trunks. Measurements were done in eight subsequent years (2001-2008) at the start of the dry season in the four corners of each plot.

Study plots were divided into the following two groups to compare effects of flooding during our observation period: 1) non-annually flooded (NAF) stands, where the flooding occurred not regularly and maximum flood level over ground was $1.0 \mathrm{~m}$ with inundation periods of up to two months and 2) annually flooded (AF) stands, where the flooding occurred every year, reaching between 1.0 and $3.5 \mathrm{~m}$ and inundation lasted for two to five months.NAF stands are represented with 13 plots and AF stands with 17 plots.

\subsubsection{Data collection and analysis}

In the inventory, all stems of living trees with a DBH (Diameter at Breast Height) $\geq 5 \mathrm{~cm}$ were included. The diameter at breast height of all stems was recorded with a fiberglass tape at 1.3 m.Diameters of buttressed trees were measured immediately above the buttresses to avoid overestimation (Condit 1998). Tree heights were measured with a telescope pole of 15 m length; the height of taller trees was estimated. Palms and lianas were not included in the inventory.Top canopy height was calculated as the mean of the 20 tallest trees per plot.The family importance value (FIV) was calculated according to Mori et al. (1983).

Tree species identificationwas conducted by a local field assistant with knowledge of the local tree flora. In addition, plant samples were collected and compared to herbarium collections at the Federal University of Tocantins in Palmas. For the classification of trees 
we followed Angiosperm Phylogeny Group III (AGP III, 2009). The scientific species names were checked in the Tropicos database (www.tropicos.org).

To estimate aboveground coarse woody biomass (AGB), we applied the allometric equation for tropical wet forests proposed by Chave et al. (2005), with wood specific gravity (WSG), dbh and tree height as parameters. WSG data for the tree species were obtained from the Global Wood Density Database (http://datadryad.org/handle/10255/dryad.235) (Zanne et al. 2009; Chave et al. 2009). In cases where species-specific information was missing, we used means of WSG calculated from the values of the species of the same genus. For the trees that could not be determined to species (7 individuals) we used the average of WSG of the respective plot.

Linear regression analyses were conducted using Xact software (SciLab, Hamburg, Germany, version 8.03). An ordination analysis (Non-metric dimensional scaling, NMDS) with Canoco 5 (Terbraak \&Šmilauer, 2012) was used to visualize how tree species composition is related to flood level and top canopy height.

\subsection{Results}

\subsubsection{Variation in flood level height and flood duration at the study site}

During the eight years of observation, the maximum level and duration of flooding varied strongly at both the spatial and temporal scale (Fig. 3). The height of flooding depended on both the quantity and distribution of local precipitation in a given year and the fluctuation of the water level in Javaés and Araguaia River, which also reflects rainfall amounts in the headwater regions. In the years 2001, 2002 and 2004, high flooding levels with maxima of $3.5 \mathrm{~m}$ were recorded which coincided with high water levels in the Javaés River. In the remaining years, water levels were lower and inundation was mainly due to high local rainfall events and accumulation of rain water in depressions. 


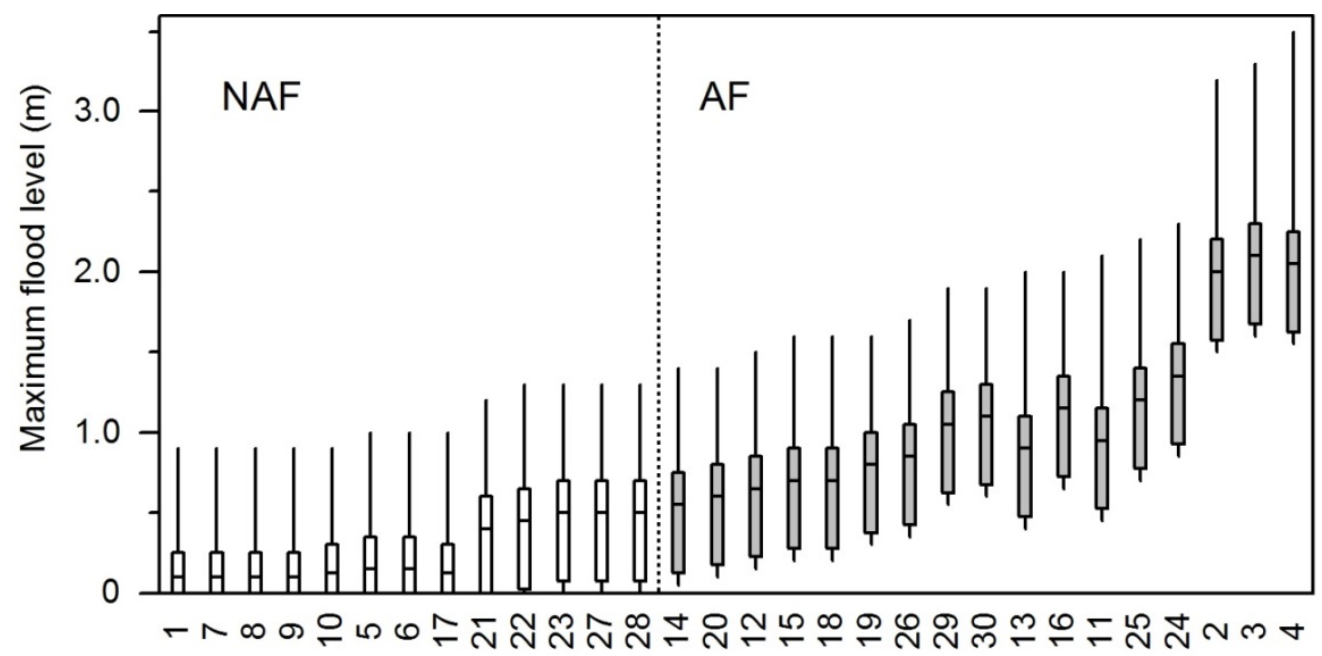

Plot ID

Figure 3. Maximum height of flooding on the study plots in the Araguaia floodplain forest as recorded during eight years (2001-2008; box-whisker plots with medians and extreme values). Plots are divided into two groups depending if they are flooded annually ( $\mathrm{AF}=$ Annually Flooded forest) or not (NAF = Non Annually Flooded forest). The plot number is given at the figure base; plots are sorted by maximum flood level.

\subsubsection{Variation in forest structure, aboveground biomass and species composition}

AGB, stem density, mean $\mathrm{DBH}$ and basal area were not significantly related to maximum flood level height in our sample (Fig. 4). Top canopy height varied between 10.5 and $18.5 \mathrm{~m}$ in the study plots. The regression analyses show that canopy height was negatively related to flood level height in the eight study years( $\mathrm{p}=0.002, \mathrm{R}^{2}=0.25$; Fig $\left.4 \mathrm{~b}\right)$, while mean WSG of the species in the plots correlated positively with flood level height $\left(\mathrm{p}<0.001, \mathrm{R}^{2}=0.43\right.$; Fig. 4d). Mean stem density and mean cumulative basal area in the Araguaia floodplain forest plots were 1040 stems ha- ${ }^{-1}$ and $19.4 \mathrm{~m}^{2} \mathrm{ha}^{-1}$, respectively. Estimated aboveground biomass (AGB, calculated after Chaves et al. 2005) varied between 60 and $235 \mathrm{Mg}$ dry mass ha $^{-1}$ (average: $116.8 \pm 22.2 \mathrm{Mg} \mathrm{ha}^{-1}$ ). 

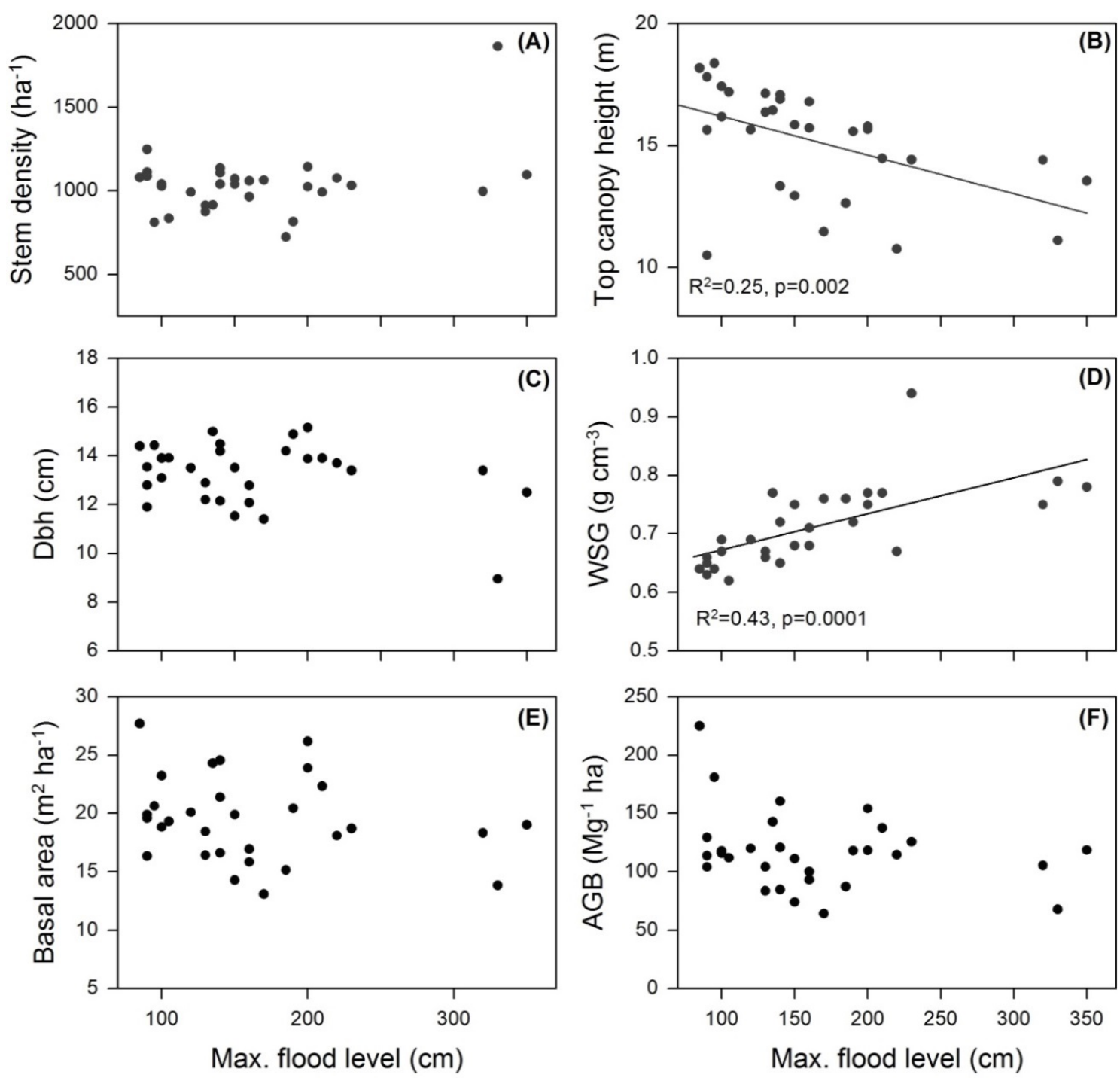

Figure 4. Plot averages of stem density A, top canopy height (B), tree DBH (C), wood specific gravity (D), basal area (E), and aboveground biomass $(\mathrm{F})$ of trees $(\mathrm{dbh} \geq 5 \mathrm{~cm})$ as a function of maximum flood level ( $\mathrm{n}=30$ plots).Regression lines are only shown where significant linear regressions were found.

The largest proportion of AGB was contributed by the $10-20 \mathrm{~cm}$ dbh class in both the NAF and the AF (Fig. 5). Larger DBH classes were increasingly less important. Large trees with $\mathrm{dbh}>50 \mathrm{~cm}$ were more important in NAF plots (contribution of $24.2 \%$ to AGB) than in AF plots (11.3\%). The large trees in NAF plots mainly are species of the families Fabaceae (2.8 
stems $\mathrm{ha}^{-1}$ ) and Vochysiaceae (1.2 stems $\left.\mathrm{ha}^{-1}\right)$. In the AF plots, most large trees were from Piranhea trifoliata $\left(1.9\right.$ stems ha $\left.{ }^{-1}\right)$ while Fabaceae were less abundant $\left(0.7\right.$ stems $\left.\mathrm{ha}^{-1}\right)$.

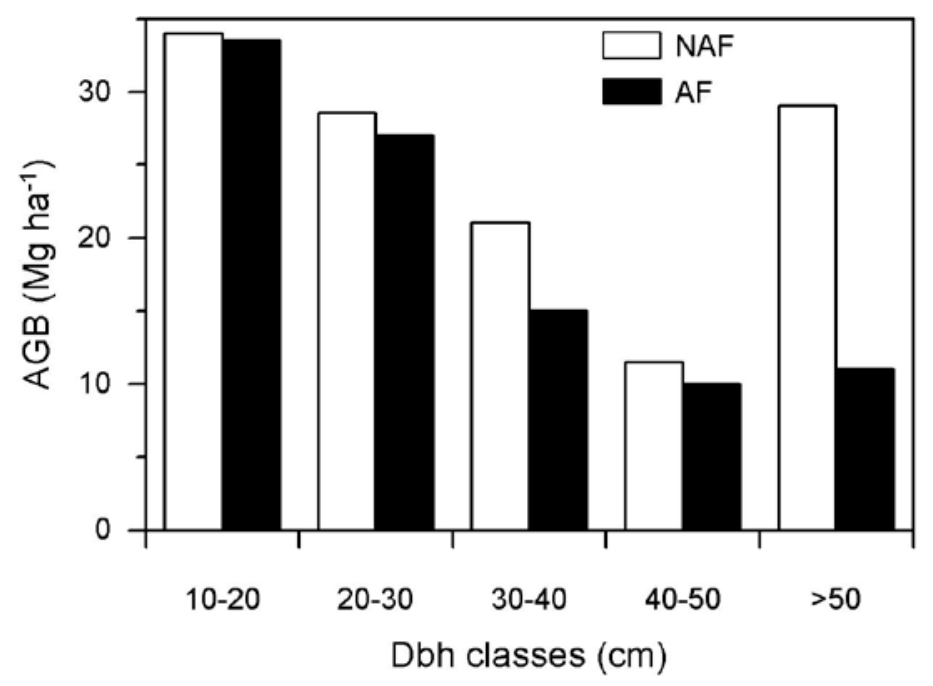

Figure 5. Aboveground biomass for five tree diameter classes in the Araguaia floodplain forest for annually flooded (AF) and non-annually flooded (NAF) forest stands.

Across all 30 plots, a total of 7598 trees of 30 families and 69 species were recorded. The species-richest family was the Fabaceae(15 species), followed by Myrtaceae(5), Rubiaceae(4) Anacardiaceae (4), Annonaceae and Boraginaceae, (3 species each, Tab.1).

The highest FIVs were calculated for the Fabaceae and Burseraceae (Tab. 2).There was no effect of flood level on species number per plots (on average we recorded 22.2 tree species per plot) and tree diversity (Shannon index) was only marginally negatively correlated with flood level $(\mathrm{p}=0.095)$. 


\begin{tabular}{|c|c|c|c|c|}
\hline Family & Scientific name & $\begin{array}{c}\text { NAF } \\
\left(\text { stems ha }^{-1}\right)\end{array}$ & $\begin{array}{c}\text { AF } \\
\left(\text { stems ha }^{-1}\right)\end{array}$ & $\mathbf{R}$ \\
\hline \multirow[t]{4}{*}{ Anacardiaceae } & Astronium fraxinifolium Schott & 2.8 & 1.7 & -0.09 \\
\hline & Spondias mombin L. & 2.7 & 0.0 & -0.12 \\
\hline & Tapirira guianensis Aubl. & 0.4 & 0.4 & \\
\hline & Tapirira obtusa (Benth.) D.J. Mitch. & 0.1 & 0.7 & \\
\hline \multirow[t]{3}{*}{ Annonaceae } & Duguetia furfuracea(A. St.-Hil.) Saff. & 16.1 & 6.3 & -0.20 \\
\hline & Unonopsis sp. & 0.0 & 0.3 & \\
\hline & Xylopia frutescens Aubl. & 40.7 & 23.6 & -0.32 \\
\hline Apocynaceae & $\begin{array}{l}\text { Himatanthus lancifolius (Mull. Arg.) } \\
\text { Woodson }\end{array}$ & 4.1 & 0.1 & -0.34 \\
\hline \multirow[t]{2}{*}{ Bignoniaceae } & Tabebuia avellanedae Lor. ex Griseb. & 0.1 & 0.3 & \\
\hline & $\begin{array}{l}\text { Tabebuia serratifolia (Vahl) } \\
\text { G.Nicholson }\end{array}$ & 6.8 & 3.2 & -0.28 \\
\hline \multirow[t]{3}{*}{ Boraginaceae } & Cordia alliodora (Ruiz \& Pav.) Oken & 57.2 & 26.9 & -0.52 \\
\hline & Cordia sellowiana Cham. & 18.8 & 5.5 & -0.32 \\
\hline & Saccellium brasiliense I.M. Johnst. & 10.5 & 19.5 & 0.74 \\
\hline \multirow[t]{2}{*}{ Burseraceae } & Protium heptaphyllum March. & 24.7 & 5.1 & -0.23 \\
\hline & Protium paniculatum March. & 157.3 & 72.3 & -0.61 \\
\hline \multirow[t]{2}{*}{$\begin{array}{l}\text { Chrysobalanacea } \\
\text { e }\end{array}$} & Hirtella glandulosa Spreng. & 0.0 & 0.4 & \\
\hline & Licania apetala (E. Mey.) Fritsch & 0.5 & 0.0 & \\
\hline \multirow[t]{2}{*}{ Clusiaceae } & Calophyllum brasiliense Cambess. & 0.4 & 0.3 & \\
\hline & Vismia guianensis (Aubl.) Pers. & 0.1 & 0.1 & \\
\hline \multirow[t]{2}{*}{ Combretaceae } & Combretum leprosum Mart. & 11.5 & 8.1 & -0.10 \\
\hline & Terminalia argenteaMart. & 0 & 0.3 & \\
\hline Dilleniaceae & Curatella americana L. & 0.4 & 1.1 & 0.20 \\
\hline Ebenaceae & Diospyros guianensis (Aubl.) Gurke & 2.5 & 0.4 & -0.39 \\
\hline Elaeocarpaceae & Sloanea guianensis (Aubl.) Benth. & 1.5 & 0.3 & -0.19 \\
\hline Erythroxylaceae & Erythroxylum manguifugum Mart. & 0.4 & 0.0 & \\
\hline \multirow[t]{2}{*}{ Euphorbiaceae } & Mabea fistulifera Mart. & 0.0 & 0.3 & \\
\hline & Sapium obovatum (Klotzsch) & 0.3 & 0.1 & \\
\hline \multirow[t]{6}{*}{ Fabaceae } & Albizia hasslerii (Chodat) Barkat & 17.6 & 10.0 & -0.18 \\
\hline & Andira sp. & 0.4 & 0.4 & \\
\hline & Bauhinia forficata Link & 10.8 & 4.7 & -0.18 \\
\hline & Cenostigma macrophyllum Tul. & 1.3 & 1.3 & -0.41 \\
\hline & Copaifera langsdorffii Desf. & 0.5 & 0.1 & \\
\hline & Dialium guianense (Aubl.) Sandwith & 0.9 & 4.9 & 0.68 \\
\hline
\end{tabular}




\begin{tabular}{|c|c|c|c|c|}
\hline & Erythrina fusca Lour. & 0.4 & 2.0 & 0.35 \\
\hline & Hymenaea courbaril L. & 3.9 & 0.0 & -0.55 \\
\hline & Inga marginata Willd. & 33.5 & 60.1 & 0.67 \\
\hline & $\begin{array}{l}\text { Peltogyne contertiflora (Mart. Ex } \\
\text { Hayne) Benth. }\end{array}$ & 0.3 & 0.4 & \\
\hline & $\begin{array}{l}\text { Sclerolobium paniculatum var. } \\
\text { rubiginosum (Mart. Ex Tul) Benth }\end{array}$ & 2.8 & 2.3 & -0.05 \\
\hline & $\begin{array}{l}\text { Sclerolobium paniculatum var. } \\
\text { subvelutinum Vogel. }\end{array}$ & 3.1 & 2.0 & 0.05 \\
\hline & $\begin{array}{l}\text { Swartzia macrostachya var. } \\
\text { macrostachya R. S. Cowan }\end{array}$ & 0.1 & 0.4 & \\
\hline & $\begin{array}{l}\text { Swartzia panacoco (Aubl.) R. S. } \\
\text { Cowan }\end{array}$ & 0.0 & 0.5 & - \\
\hline & Vitairea $s p$ & 0.1 & 0.0 & - \\
\hline Icacinaceae & Emmotum nitens (Benth.) Miers & 2.1 & 13.1 & 0.24 \\
\hline \multirow[t]{2}{*}{ Lauraceae } & Nectandra gardneri Meisn & 32.5 & 21.3 & -0.10 \\
\hline & Ocotea opifera Aubl. & 0.5 & 0.2 & \\
\hline \multirow[t]{2}{*}{ Lecythidaceae } & Cariniana estrellensis (Raddi) Kuntze & 0.5 & 0.1 & \\
\hline & Eschweilera ovata (Cambess.) Miers & 9.1 & 0.1 & -0.22 \\
\hline \multirow[t]{2}{*}{ Lythraceae } & Lafoensia glyptocarpa Koehne & 1.1 & 0.5 & -0.19 \\
\hline & Physocalimna scaberrimum Pohl & 6.2 & 0.0 & -0.28 \\
\hline Malpighiaceae & Byrsonima intermedia A. Juss. & 0.2 & 0.4 & \\
\hline Malvaceae & Ceiba boliviana Britton \& Baker f. & 2.9 & 0.3 & 0.36 \\
\hline \multirow[t]{2}{*}{ Melastomataceae } & Bellucia grossularioides L.Triana & 0.0 & 0.1 & \\
\hline & Mouriri guainensis Aubl. & 49.2 & 55.3 & 0.43 \\
\hline \multirow[t]{2}{*}{ Moraceae } & Brosimum rubescens Taub. & 0.3 & 0.4 & \\
\hline & Sorocea guilleminiana Gaudich. & 1.5 & 1.1 & 0.02 \\
\hline \multirow[t]{5}{*}{ Myrtaceae } & Calycorectes psidiiflorus (Bg.) Sobral & 0.9 & 0.1 & -0.35 \\
\hline & $\begin{array}{l}\text { Campomanesia guazumifolia } \\
\text { (Cambess.) O.Berg }\end{array}$ & 0.7 & 0.1 & \\
\hline & Myrcia fallax (Rich.) DC. & 0.4 & 1.5 & 0.28 \\
\hline & Psidium myrtoides O. Berg & 0.1 & 0.0 & \\
\hline & Siphoneugena densiflora Berg & 0.3 & 0.1 & \\
\hline Picrodendraceae & Piranhea trifoliata Baju. & 13.7 & 23.2 & 0.52 \\
\hline Primulaceae & $\begin{array}{l}\text { Cybianthus gardneri (A. DC.) G. } \\
\text { Agostini }\end{array}$ & 0.0 & 2.3 & 0.37 \\
\hline \multirow[t]{4}{*}{ Rubiaceae } & Alibertia edulis (A. Rich) A. Rich. & 2.5 & 57.6 & 0.58 \\
\hline & $\begin{array}{l}\text { Calycophyllum spruceanum (Benth.) } \\
\text { Hook }\end{array}$ & 0.7 & 0.1 & \\
\hline & Genipa americana L. & 0.0 & 0.3 & \\
\hline & $\begin{array}{l}\text { Guettarda viburnoides Cham. E } \\
\text { Schltdl. }\end{array}$ & 0.3 & 0.0 & \\
\hline Sapotaceae & Manilkara salzmannii (A.DC.) H.J.Lam & 0.1 & 0.3 & \\
\hline Urticaceae & Cecropia sp. & 1.1 & 0.1 & -0.11 \\
\hline Vochysiaceae & Vochysia tucanorum Mart & 3.0 & 1.2 & -0.73 \\
\hline
\end{tabular}




\begin{tabular}{|c|c|c|c|c|c|c|c|c|}
\hline & \multicolumn{4}{|c|}{ NAF } & \multicolumn{4}{|c|}{ AF } \\
\hline Family & $\begin{array}{c}\text { No. of } \\
\text { species }\end{array}$ & $\begin{array}{c}\text { Stem } \\
\text { density } \\
\left(\mathrm{ha}^{-1}\right)\end{array}$ & $\begin{array}{c}\text { Basal } \\
\text { area } \\
\left(\mathrm{m}^{2} \mathrm{ha}^{-1}\right)\end{array}$ & FIV & $\begin{array}{c}\text { No. of } \\
\text { species }\end{array}$ & $\begin{array}{c}\text { Stem } \\
\text { density } \\
\left(\mathrm{ha}^{-1}\right)\end{array}$ & $\begin{array}{c}\text { Basal } \\
\text { area } \\
\left(\mathrm{m}^{2} \mathrm{ha}^{-1}\right) \\
\end{array}$ & FIV \\
\hline Anacardiaceae & 4 & 3.1 & 0.1 & 13.8 & 3 & 3.3 & 0.1 & 10.5 \\
\hline Annonaceae & 2 & 87.1 & 1.7 & 15.7 & 3 & 94.6 & 1.6 & 21.1 \\
\hline Apocynaceae & 1 & 9.2 & 0.5 & 5.4 & 1 & 0.2 & 0.0 & 3.4 \\
\hline Bignoniaceae & 1 & 8.3 & 0.4 & 5.4 & 2 & 12.5 & 0.6 & 10.3 \\
\hline Boraginaceae & 3 & 66.2 & 0.7 & 14.4 & 3 & 54.4 & 0.6 & 14.4 \\
\hline Burseraceae & 2 & 344.3 & 4.3 & 32.3 & 2 & 192.7 & 2.5 & 24.9 \\
\hline Chrysobalanaceae & 1 & 0.3 & 0.1 & 3.6 & 2 & 1.4 & 0.0 & 6.8 \\
\hline Clusiaceae & 2 & 0.9 & 0.0 & 6.8 & 1 & 0.7 & 0.0 & 3.5 \\
\hline Combretaceae & 1 & 25.2 & 0.3 & 5.0 & 2 & 17.4 & 0.2 & 8.1 \\
\hline Dilleniaceae & 1 & 0.9 & 0.0 & 3.4 & 1 & 1.9 & 0.1 & 3.7 \\
\hline Ebenaceae & 1 & 5.2 & 0.2 & 4.2 & 1 & 1.4 & 0.0 & 3.5 \\
\hline Elaeocarpaceae & 1 & 4.0 & 0.1 & 4.0 & 1 & 0.2 & 0.0 & 3.4 \\
\hline Erythroxylaceae & 1 & 0.9 & 0.0 & 3.4 & 0 & 0.0 & 0.0 & 0.0 \\
\hline Euphorbiaceae & 0 & 0.0 & 0.0 & 0.0 & 2 & 0.7 & 0.0 & 6.8 \\
\hline Fabaceae & 14 & 197.2 & 4.3 & 69.0 & 12 & 198.8 & 3.1 & 63.1 \\
\hline Icacinaceae & 1 & 0.6 & 0.0 & 3.4 & 1 & 25.9 & 0.6 & 7.2 \\
\hline Lauraceae & 1 & 17.2 & 0.2 & 4.4 & 1 & 59.8 & 0.6 & 8.1 \\
\hline Lecythidaceae & 2 & 12.3 & 0.4 & 8.5 & 1 & 9.9 & 0.3 & 5.4 \\
\hline Lythraceae & 2 & 16.6 & 0.9 & 10.9 & 2 & 1.4 & 0.0 & 6.9 \\
\hline Malpighiaceae & 2 & 1.2 & 0.1 & 6.9 & 1 & 0.2 & 0.0 & 3.3 \\
\hline Malvaceae & 1 & 5.2 & 0.4 & 5.0 & 1 & 1.2 & 0.1 & 3.7 \\
\hline Melastomataceae & 1 & 80.0 & 1.3 & 10.5 & 1 & 125.4 & 1.9 & 16.8 \\
\hline Moraceae & 2 & 36.9 & 2.7 & 18.7 & 2 & 61.7 & 1.1 & 14.4 \\
\hline Myrsinaceae & 0 & 0.0 & 0.0 & 0.0 & 1 & 4.0 & 0.0 & 3.6 \\
\hline Myrtaceae & 3 & 3.7 & 0.1 & 10.4 & 5 & 4.9 & 0.0 & 17.0 \\
\hline Picrodendraceae & 1 & 2.2 & 0.7 & 6.3 & 1 & 57.9 & 2.4 & 17.8 \\
\hline Rubiaceae & 5 & 8.0 & 0.2 & 17.5 & 2 & 108.7 & 1.4 & 17.0 \\
\hline Sapotaceae & 0 & 0.0 & 0.0 & 0.0 & 1 & 0.7 & 0.1 & 4.0 \\
\hline Urticaceae & 1 & 1.5 & 0.0 & 3.4 & 1 & 0.7 & 0.0 & 3.4 \\
\hline Vochysiaceae & 1 & 7.4 & 1.0 & 7.6 & 1 & 1.7 & 0.1 & 3.9 \\
\hline
\end{tabular}




\subsubsection{Relationships between species abundance and flood level height}

The majority of the more common species in the Araguaia floodplain forest (24 of 37 species) showed a negative relation between stem density per hectare and maximum flood level height (Tab. 1). This relation was strongest (highest R) in Vochysiatucanorum, Protiumpaniculatum, Hymenaeacourbaril, andCordiaalliodora.The relatively common Fabaceae Hymenaeacourbaril was completely absent in AF plots, which may indicate elevated flooding sensitivity.

Thirteen of the 37 more common species revealed a positive relation between abundance and maximum flood level height. Apparent affinity to flooding was largest in Saccelliumbrasiliense, Dialiumguianense, Inga marginata, AlibertiaedulisandPiranhea trifoliata. A few species such as Cybianthusgardneriwere exclusively recorded in AF plots; this species is a good indicator for highly flooded areas in the Araguaia floodplain forest.

The four most abundant species in the floodplain forest showed opposing stem densities flood level relationships (Fig 6). The stem density of Mouririguianenesisand Ingamarginata increased with maximum inundation height $(\mathrm{p}=0.009$ and $\mathrm{p}<0.001$, respectively), while opposite trends were observed in Protiumpaniculatum and Cordiaalliodora $(\mathrm{p}=0.001$ and $\mathrm{p}=0.002$, respectively). 

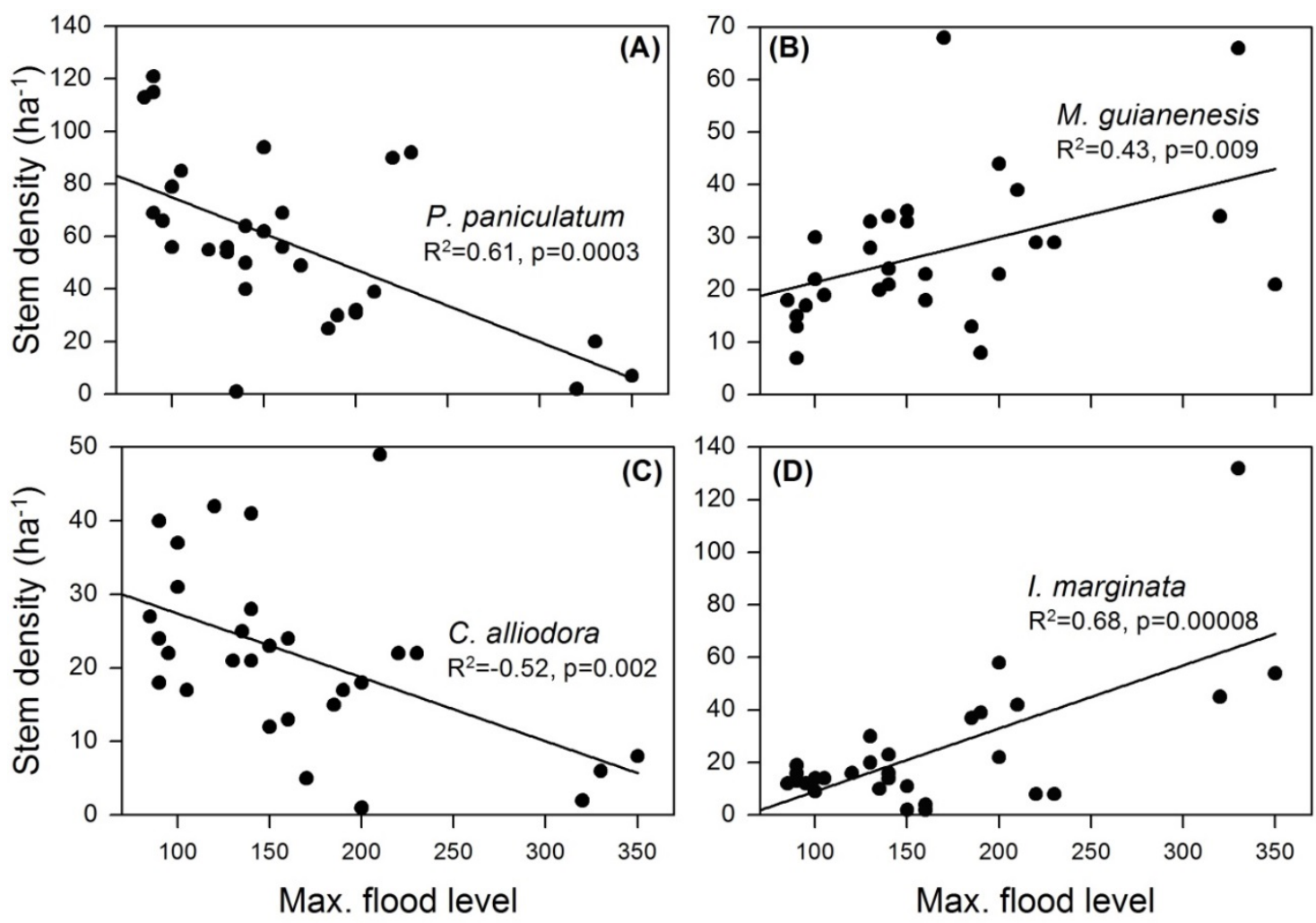

Figure 6. Stem densities of the four most common tree species Protium paniculatum (Burseraceae), Mouriri guianenesis (Melastomataceae), Cordia alliodora (Boraginaceae), and Inga marginata (Fabaceae) in Araguaia floodplain forest in relation to maximum flood level.

The NMDS ordination plot (Fig 7) shows that on the one hand flood level has a strong influence on floristic composition of the study plots and that on the other hand an increasing flood level is accompanied by smaller-sized trees. 


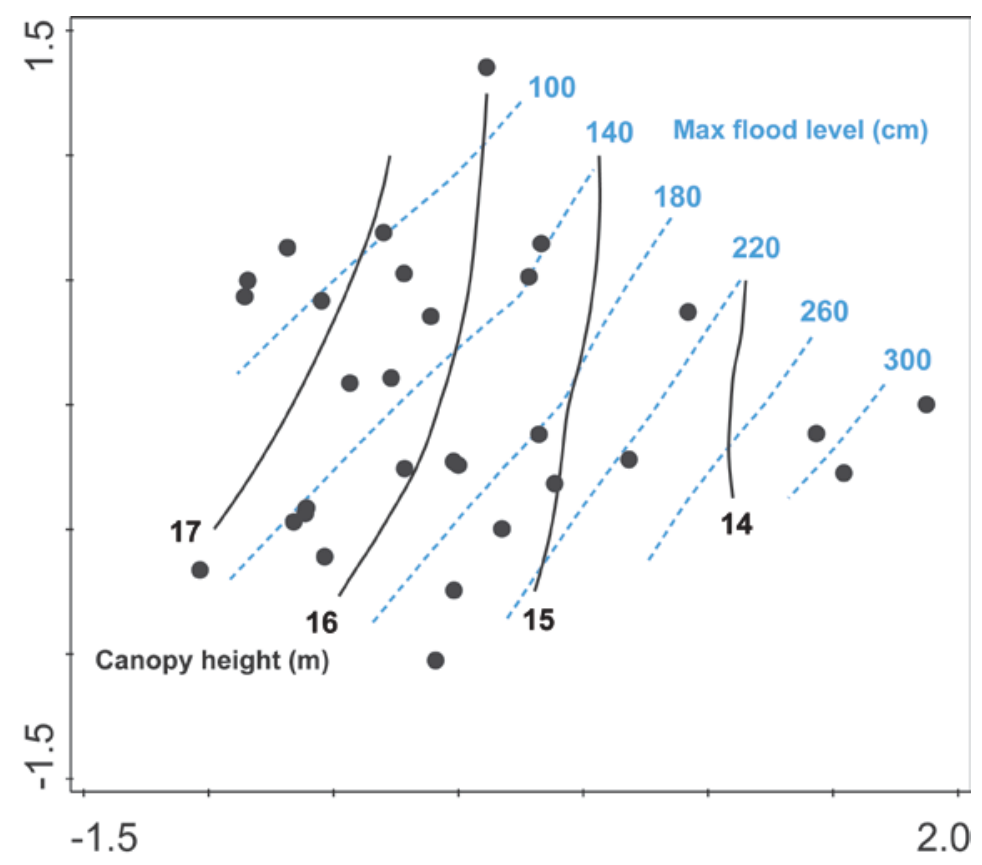

Figure 7. Contour plot showing the results of a NMDS ordination based on tree species composition of the 30 study plots (black dots) and attributes (top canopy height and maximum flood level) visualized by isolines.

\subsection{Discussion}

Eight years of flood level observation revealed that inundation events occur highly irregularly in the Araguaia floodplain forests. We registered marked differences in flooding duration and maximum water level. The flood level was not only dependent on forest topography and the local micro-relief, but also was influenced by precipitation quantity and distribution in the years. The main determinant of flooding was the water level of the Javaés and Araguaia rivers and also high amounts of local rainfall which led to temporal flooding of low-lying terrain. The typical monomodal, predictable and pronounced flood pulse pattern known from the Central Amazon (Junk 1989) was not observed in the Araguaia floodplain.

Some várzea tree species are subject to annual inundations that reach up to $7 \mathrm{~m}$ in height and last up to 230 days year $^{-1}$ (Junk, 1989;Wittmann et al. 2002; Wittmann et al. 2004).In the 
Araguaia floodplain forest, water level height and flooding duration are less extreme. The highest recorded water level during our study period was $3.5 \mathrm{~m}$ and the length of the inundation period did not exceed 150 days.

Tree and canopy height, tree species composition and wood density were the stand structural and tree morphological properties with largest variation across the topographic gradient in the floodplain. Tree height was greater in the non-annually flooded stands (NAF) than in the annually flooded forest (AF), and stand height decreased linearly with increasing maximum flood level height. This clearly indicates that the extent of flooding is one of the key determinants of tree growth in the floodplain forests. However, with a maximum tree height of $25 \mathrm{~m}$ in the NAF plots, tree size is considerably smaller (about two times) than in the central Amazonian forest, even though flood levels are often higher there (Junk 1989). This suggests that additional abiotic factors such as limited soil nutrient availability or seasonal drought must constrain tree growth in the Araguaia region, or that tree species with lower height growth potential are dominating the forests at the margins of the Amazon basin. The first might be particularly understandable regarding Amazonian tree species reaching the distributional limit of their natural range, whereas the second point is supported by the generally smaller stature of cerrado tree species. The linear increase in wood specific gravity with maximum flood level height suggests that temporal anoxia in combination with the mechanical stress of the river current favor tree species with higher tissue density, thus supporting the results reported by Wittmann et al. (2006b) from a Central Amazonian várzea forest.

The other important constraint, drought, apparently had only a relatively small influence on the wood density of the floodplain forest trees. In many other regions, drought triggers the formation of smaller conduits in the stem xylem and often favors trees with higher wood specific gravity. Most likely, this influence was overlain by a dominant inundation effect. Interestingly, mean DBH, stem density and basal area remained invariant across the gradient of maximum flood level height, and so did estimated aboveground live biomass. This suggests that the marked decrease in mean tree height toward sites with higher flooding must have in part, or fully, been compensated by the wood density increase from the low- to the high-inundation sites. Higher flooding also led to the disappearance of a closed second 
canopy layer in the forest which was present in the NAF stands but was lacking in the AF stands at lower elevation (personal observation).

We counted on average 1040 stem $\geq 5 \mathrm{~cm} \mathrm{dbh} \mathrm{ha}^{-1}$ and found the highest abundance of stems in the smallest diameter class. This is similar to stand structural patterns reported from other Amazonian inundation forests (e.g. Ferreira, 1991; Campbell et al. 1992; Ayres, 1993).

With on average 116.8 $\mathrm{Mg} \mathrm{ha}^{-1}$, the Araguaia floodplain forest had a low AGB value, equaling only $\sim 30-60 \%$ of the mean biomass of Amazonian terra firme forests which is estimated to range between 200 and $400 \mathrm{Mg} \mathrm{ha}^{-1}$ (Castilho et al. 2006; DeWalt and Chave 2004; Baker et al.2004; Laurance et al.1999; Malhi et al.2006; Nascimento \& Laurance 2002). Our AGB figure is also smaller than the biomass reported from western Amazonian várzea forests (195-357 $\mathrm{Mg} \mathrm{ha}^{-1}$; Malhi et al. 2006) and the 136-260 $\mathrm{Mg} \mathrm{ha}^{-1}$ found in the cerrado floodplains of the Pantanal (Schöngart et al. 2011: excluding one plot with unusually low biomass; Wittmann et al. 2008). Correspondingly, stand basal area was also low in Araguaia with a mean of $19.4 \mathrm{~m}^{2} \mathrm{ha}^{-1}$. For Eastern Amazonian várzea forests, $32.0 \pm$ $10.3 \mathrm{~m}^{2} \mathrm{ha}^{-1}$ were reported (Almeida et al. 2004); the mean for Central Amazonian terra firme forests is even higher (32.8 to $40.2 \mathrm{~m}^{2} \mathrm{ha}^{-1}$; Ferreira and Prance, 1998) and in the Pantanal also high values up to 37.5-47.8 $\mathrm{m}^{2} \mathrm{ha}^{-1}$ were recorded (Schöngart et al. 2011; Wittmann et al. 2008). Low AGB and basal area are mainly caused by the scarcity of large trees in the Araguaia forest. Clearly, we cannot be entirely sure that large trees have been logged in these forests in the past, even though the area is part of the well-preserved Cantão State Park. However, the contribution of large trees $(\mathrm{dbh}>50 \mathrm{~cm})$ to AGB was much higher in NAF plots (24.2 \%) with better accessibility than in AF plots closer to the river (11. 3\%). This suggests that the absence of large-diameter trees in the annually flooded forest should at least partly be a natural phenomenon, probably related to elevated mortality.

Although known to be the richest floodplain forests in world (Wittmann et al., 2006a) they usually do not reach the tree diversity of terra firme or upland forests. Campbell et al. (1992) found 20 tree species $\mathrm{ha}^{-1}(>10 \mathrm{~cm}$ dbh) in várzeaforests of the Rio Xingu, Brazil compared to the figure of 137-168 species ha $^{-1}$ for Central Amazonian terra firme forests (Ferreira and Prance 1998). In the total investigated stand area of 7.5 ha, we recorded 30 
families and 69 species only. In contrast to our results, that showed almost no effect of flooding on tree diversity, Ayres (1993), Ferreira (1997), Ferreira and Stohlgren(1999) and Haugaasen and Peres (2006) found evidence that the species richness of floodplain forests decreases with the height and duration of the flooding. Assis and Wittmann (2011) reported that stem densities and tree species richness were considerably higher in the high várzea than in the low várzea, which suggests that the height and duration of the annual flooding area main driver of tree species richness by limiting tree regeneration and establishment.In addition, Assis et al. (2014) found that floristic diversity and composition are more influenced by the hydroperiod than by substrate conditions and that substrate conditions become less important for increasingly flood-tolerant species. In the Araguaia floodplain, possible positive effects of shorter flooding on species richness areapparently offset by the stronger water limitation during dry season.

The family importance value (FIV) was highest for the Fabaceae and Burseraceae with a dominantrole being played by the former family (Tab. 2). The great abundance of Fabaceae species matches the floristic composition of many tropical moist forests of central Amazonia (Fereira and Prance 1998, Wittmann et al. 2013, Assis et al. 2014). In várzea and igapó forests of central Amazonia, Fabaceae and Euphorbiaceaehave frequently been found to be dominant (Ayres 1986, 1993; Keel and Prance, 1979; Ferreira, 1997). In the Araguaia forest, additional species-rich and abundant families wereMoraceae, Rubiaceae and Annonaceae in not annually flooded plots (NAF) and Annonaceae, Picrodendraceae and Myrtaceae in annually flooded plots (AF).

The four tree species with highest stem densities in the Araguaia floodplain forests were Protiumpaniculatum,Cordia alliodora, Mouririguianenesisand Inga marginata, all species with a wide distribution across Amazonia. This supports the findings of Assis et al. (2015) that many floodplain tree species are generalists occurring across a wide range of substrate and flooding conditions. However, they seem to represent fundamentally different tree functional types, because two species ( $P$. paniculatumand $C$. alliodora) showed increasingstem densities with decreasing maximum flooding height, i.e. apparent avoidance of inundation, while the other two species (M.guianenesisandI. marginata) were more abundant in the AF forest than in NAF areas. The latter species must have developed 
successful strategies to tolerate long-lasting anoxia not only in the adult stage but also as seedlings, which could be entirely submerged for up to five months. Both species have also been identified as most common flood tolerant tree species of the Pantanal, an area with comparable climatic conditions (Wittmann 2012). An exceptional species seems to be the Rubiaceae.Alibertiaedulis which was abundant in the AF areas but nearly absent in plots with non-annual inundation. We speculate that this species has not only achieved a very high tolerance of long-lasting submergence, but also seems to be able to rapidly colonize gaps in the annually-flooded forest, likely profiting from the failure of other less successful species. This species has been found to be particularly sensitive to drought stress (Nunes da Cunha \& Junk 2004).On the other hand, we found typical savanna species like Curatellaamericana (Dilleniaceae);this tree is adapted to harsh soil conditions (nutrient and water limitation) and even to the periodic fire events (Foldats\&Rutkis 1975; Medina \&Silva 1990) typical occurring in the cerrado.

\subsection{Conclusions}

There is a high inter-annual variation in flooding levels in the Araguaia floodplain, but flood duration is on average two times shorter and flood level is four times lower than in typical várzea or igapóforests of theCentral Amazon. A further difference with these forests is the occurrence of a completely dry period of three months.

Although there was no significant effect of flooding on tree diversity, tree species composition and family importance values differed markedly between AF and NAF. This shows that habitat colonization by trees in the Araguaia floodplain is strongly linked to resistance and adaptation to flooding. The influence of flooding as a driver of forest structure was manifested by its negative influence oncanopy height and by a positive correlation with WSG of the recorded tree species.

Family composition is similar to Central Amazonian floodplain forests and many widely distributed flood-tolerant tree species are shared. The by far lower AGB is probably a result 
of the lower soil fertility combined with the pronounced dry season in the Araguaia floodplain.

In view of the predicted increase of extended drought periods we assume that future forests in the study area most likelywill lose those tree species which are not drought-tolerant enough, and as a further consequence, AGB will decline when the growth limitation increases.

\section{Acknowledgments}

This research was conducted as a component in the "Carbon Sequestration Project in Bananal Island” sponsored by AES Barry Foundation. We are grateful for support to the NGO Instituto Ecológica, Palmas and Federal University of Tocantins, Palmas. We thank Antonio Moralesfor tree identification and Florian Geipelfor assistance with field work. DK receivedscholarships from CNPq (Brazilian National Council for Scientific and Technological Development) and from KAAD (Catholic Academic Exchange Service). We thank two anonymous reviewers for their helpful comments on an earlier version of the manuscript. 


\section{References}

Almeida, S.S., Amaral, D.D., Silva, A.S., 2004. Análiseflorística e estrutura de florestas de várzea no estuário amazônico. ActaAmazônica34, 513-524.

APG (The Angiosperm Phylogeny Group) III 2009. An update ofthe Angiosperm Phylogeny Group classification for theorders and families of flowering plants: APG III. Botanical Journal of the Linnean Society 161: 105-121.

Assis, R.L. and Wittmann, F., 2011.Forest structure and tree species composition of the understory of two central Amazonian várzea forests of contrasting flood heights.Flora 206, 251-260.

Assis, R.L.,Haugaasen, T., Schöngart,J., Montero, J.C., Piedade, M.T.F. and Wittmann, F.2015.Patterns of tree diversity and composition in Amazonian floodplain paleo-várzea forest.Journal of Vegetation Science 26, 312-322

Assis, R.L.,Wittmann, F., Piedade, M.T.F. and Haugaasen, T. 2015.Effects of hydroperiod and substrate properties on tree alpha diversity and composition in Amazonian floodplain forests. Plant Ecology 216, 41-54.

Ayres, J.M. 1986. Uakaris and Amazonian flooded forest.PhD thesis, University of Cambridge, Cambridge, 338p.

Ayres, J.M., 1993.As matas de várzea do Mamirauá. In: Sociedade Civil Mamirauá (Ed.), Estudos de Mamirauá, vol. 1. CNPq, Brasilia, 1-123.

Baker, T.R, Phillips, O.L., Malhi, Y., Almeida, S., Arroyo, L.,Di Fiore, A., Erwin, T., Killeen, T.J, Laurance, S.G, Laurance, W.F., Lewis, S.L, Lloyd, J., Monteagudo, A., Neill, D.A., Patino, S., Pitman, N.C.A., Silva, J.N.M, Vasquez, R. 2004. Variation in wood density determines spatial pat- terns in Amazonian forest biomass. Glob Change Biol 10: 545-562.

Borma, L.D.S., Da Rocha, H.R., Cabral, O.M., Von Randow, C., Collicchio, E., Kurzatkowski, D., Brugger, P.J., Freitas, H., Tannus, R., Oliveira, L., Rennó, C.D. and Artaxo, P. 2009. Atmosphere and hydrological controls of the evapotranspiration over a floodplain forest in the Bananal Island region, Amazonia. Journal of Geophysical Research, 114, G01003. 
Campbell, D.G., Stone, J.L., Rosas, A. 1992. A comparison of the phytosociology and dynamics of three (várzea) forests of known ages, Rio Jurua, Western Brazilian Amazon.J. Linnean Soc.108, 213-237.

Castilho, C.V., Magnusson, W.E., Araújo, R.N.O., Luizã, R.C.C., Luizão, F.J., Lima, A.P., Higuchi, N., 2006. Variation in aboveground tree live biomass in a central Amazonian Forest: effects of soil and topography, For. Ecol. Manag., 234, 85-96.

Chave, J., Andalo, C., Brown, S., Cairns, M.A., Chambers, J.Q., Eamus, D, Folster, H., Fromard, F., Higuchi, N., Kira, T., Lescure, J.P., Nelson, B.W., Ogawa, H., Puig, H., Riera, B., Yamakura, T., 2005. Tree allometry and improved estimation of carbon stocks and balance in tropical forests. Oecologia 145, 87-99.

Chave, J., Coomes, D.A., Jansen, S., Lewis, S., L., Swenson, N.G., Zanne, A.E., 2009.Towards a worldwide wood economics spectrum. Ecology Letters 12(4), 351-366. Condit, R., 1998. Tropical Forest Census Plots.Springer-Verlag, Berlin and R. G. Landes Company: Georgetown, Texas.

Departamento Nacional de Produção Mineral (DNPM), 1978. Projecto RADAMBRASIL. FolhaSC. 20 Porto Velho; geologia, geomorfologia, pedologia, vegetação e uso potencial da terra. Anexo: Analise estistitica de dados (Vegetacão). Departamento Nacional de Produção Mineral, Rio de Janeiro, Brazil.

DeWalt,S.J., Chave, J., 2004. Structure and biomass of four lowland Neotropical forests.Biotropica36, 7-19.

Eiten, G., 1985. Vegetation near Santa Teresinha, NE Mato Grosso. Acta Amazônica, v.15, n.3/4, p.275-301.

Fereira, L.V., 1991. O efeito do periodo de inundacao na distribuicao a fenologia e regeneracão de plantas em uma Foresta de igapo na Amazonia Central. INPA, Brasil. Ferreira, L.V., 1997.Effects of the duration of flooding on species richness and floristic composition in three hectares in the Jaú National Park in floodplain forests in central Amazonia. Biodiversity and Conservation 6, 1353-1363. 
Fereira, L.V.\& Prance, G.T., 1998.Species richness and floristic composition in four hectares in the Jau National Park in upland forest in Central Amazonia”.Biodiversity and Conservation 7, 1349-1364.

Ferreira, L.V.\&Stohlgren T.J., 1999.Effects of river level fluctuation on plant species richness, diversity and distribution in a floodplain forest in Central Amazonia. Oecologia 120(4), 582-587.

Foldats, E. \&Rutkis E., 1975. Ecological studies of chaparro (Curatellaamericana) and manteco (Byrsonimacrassifolia) in Venezuela. Journal of Biogeography 2, 159-178.

Gopal, B., Junk, W.J., Davis, J.A.,(eds).2000. Biodiversity in Wetlands: Assessment, Function and Conservation, Volume 1. Backhuys Publishers: Leiden, The Netherlands.

Haugaasen, T, Peres, C.A. 2006. Floristic, edaptic and structural characteristics of flooded and unflooded forest in the lower Rio Purus región of central Amazonia, Brasil.ActaAmazonica 36,25-36.

Herrera, A. 2013. Responses to flooding of plant water relations and leaf gas exchange in tropical tolerant trees of a black-water wetland. Frontiers in Plant Science, 4:106.

Houghton, R.A., Skole, D.L., Nobre, C.A., Hackler, J.L., Lawrence, K.T., Chomentowski, W.H., 2000.Annual fluxes of carbon from deforestation and regrowth on the Brazilian Amazon. Nature 403, 301-304.

Joly, C.A., 1994.Flooding tolerance: a reinterpretation of Crawford's metabolic theory. Proc. R. Soc. Edinb.102B, 343-354.

Junk, W., 1996.Ecology of floodplains and challenge for tropical limnology. In: Shiemer F., Boland K., T. (Eds.). Perspectives in Tropical Limnology. SPB Academic Publishing, Amsterdam, pp. 255-265.

Junk, W., 1989.Flood tolerance and tree distribution in central Amazonian floodplains. In: Holm-Nielsen L., B., Nielsen I., C., Balslev H., (Eds.), Tropical Forests: Botanical Dynamics, Speciation and Diversity. Academic Press, London, pp. 47-64. 
Junk, W.J., Piedade, M.T.F., Schöngart, J., Cohn-Haft, M., Adeney, J. M., Wittmann, F., 2011.A classification of major naturally-occurring Amazonian lowland wetlands.Wetlands31(4), 623-640.

Ketterings, Q.M., Coe, R., Noordwijk, M., van Ambagau, Y., Palm, C.A., 2001. Reducing uncertainty in the use of allometric biomass equations for predicting above-ground tree biomass in mixed secondary forests. For Ecol Manage 146, 199-209.

Keel, S.H., \& Prance, G.T. 1979.Studies of the vegetation of a white-sand black-water igapó (Rio Negro, Brazil).ActaAmazonica 9: 645-655.

Kozlowski, T.T., 1984. Plant responses to flooding of soil. BioScience34 3, pp. 162-166. Laurance, W.F., Fearnside, P.M., Laurance, S.G., Delamonica, P., Lovejoy, T.E., Rankin-de Merona, J.M., Chambers, J.Q., Gascon C., 1999. Relationship between soils and Amazon forest biomass: a landscape-scale study. For. Ecol. Manag.118, 127-138.

Lourival, R., Drechsler, M., Watts, M.E., Game, E.T., Possingham, H.P.,2011.Planning for reserve adequacy in dynamic landscapes; maximizing future representation of vegetation communities under flood disturbance in the Pantanal wetland. Diversity and Distributions17,297-310.

Malhi, Y.R., Wood, D., Baker, T.R., Wright, J., Phillips, O., L., Cochrane, T., Meir, P., Chave, J., Almeida, S., Arroyo, L., Higuchi, N., Killeen, T.J., Laurance, S.G., Laurance, W.F., Lewis, S.L., Monteagudo, A., Neill, D.A., Nunez, P., Pitman, N.C.A., Quesada, C., A., Salomao, R., Silva, J., Torres, N.M.,Lezada, A., Terborgh, J., Vasquez, J., Martinez, R., Vinceti, B., 2006.The regional variation of aboveground live biomass in old-growth Amazonian forests.Glob Change Biol. 12:1107-1138.

Martins, A. \& Kardec, E., 2006. Relações solo-geoambiente em áreas de ocorrências de Ipucas na planície do Médio Araguaia - Estado de Tocantins.Rev. Árvore [online].2006, vol.30, n.2, pp. 297-310.ISSN 0100-6762.

Medina, E. \& Silva J.F., 1990.Savannas of northern South America: a steady state regulated by water-fire interactions on a background of low nutrients availability. Journal of Biogeography 17: 403-413. 
Melack J., M. \&Hess L.L., 2010.Remote sensing of the distribution and extent of wetlands in the Amazon basin. - In: Junk W. J. et al. (eds), Amazonian floodplain forests. Ecophysiology, biodiversity and sustainable management.Ecological Series 210.Springer, pp. 43-59.

Mori, S.A., Boom, B.M., de Carvalho, A.M., dos Santos, T.S., 1983. Southern Bahian moist forests. Bot. Rev. 49 (2), 155-232.

Nascimento, H.E.M.\& Laurence, W.F. 2002. Total aboveground biomass in central Amazonian rainforests - a landscape-scale study, For. Ecol. Manag, 168, 311-321.

Nunes da Cunha, C.\& Junk, W.J., 2004. Year-to-year changes in water level drive the invasion of Vochysiadivergens in Pantanal grasslands. Applied Vegetation Science 7, 103110.

Nunes da Cunha, C.\&Junk W.J., 2011.Landscape units of the Pantanal: structure, function and human use. In:The Pantanal: Ecology, Biodiversity and Sustainable Management of a Large Neotropical Seasonal Wetland, Junk W.,J., da Silva C., J., Nunes da Cunha C., Wantzen K., M., (eds). Pensoft: Sofia/Moscow; 299-324.

Olivares, I., Svenning, J.C., van Bodegom, PM. and Balslev, H. 2015. Effects of warming and drought on the vegetation and plant diversity in the Amazon basin. The Botanical Review, 81(1), 42-69.

Parolin, P., Oliveira, A.C., Piedade, M.T.F., Wittmann, F., Junk, W.J., 2002. Pioneer trees in Amazonian floodplains: key species form monospecific stands in different habitats. Folia Geobotanica37, 225-238.

Parolin, P. 2001.Morphological and physiological adjustments to waterlogging and drought in seedlings of Amazonian floodplain trees.Oecologia 128, 326-335.

Parolin, P. 2010. Flood-tolerant trees of Amazonian floodplains also tolerate drought. Pesquisas, Botânica, 61, 7-38.

Parolin, P., Lucas, C., Piedade, M.T.F., Wittmann, F. 2010. Drought responses of floodtolerant trees in Amazonian floodplains. Ann Bot 105 (1), 129-139. 
Piedade,M.T.F., Junk W.J., Parolin, P., 2000. The flood pulse and photosynthetic response of trees in a white water floodplain (várzea) of the central Amazon, Brazil.

Verh.Internat.Verein Limnol.27, 1734-1739.

Prance,G.T., 1979. Notes on the vegetation of Amazonia III. The terminology of Amazonian forest types subject to inundation. Brittonia3, 26-38.

Schimel, D.S., 1995.Terrestrial ecossystems and carbon cycle.Glob Change Biol 1, 77-91 Schöngart,J.,Wittmann, F., Worbes, M.,2010. Biomass and net primary production of Central Amazonian floodplain forests. In Amazonian Floodplain Forests: Ecophysiology, Biodiversity and Sustainable Management, Junk WJ, Piedade MTF, Wittmann F, Schöngart J, Parolin P (eds). Ecological Studies 210, Springer Verlag: Berlin/ Heidelberg/New York; 347-388.

Schöngart, J., Arieira, J., Felfili Fortes, C., Cezarine de Arruda, E., \& Nunes da Cunha, C. 2011. Age-related and stand-wise estimates of carbon stocks and sequestration in the aboveground coarse wood biomass of wetland forests in the northern Pantanal, Brazil. Biogeosciences, 8(11), 3407-3421.

Terbraak, C.J.F. \& Šmilauer, P., 2012. Canoco reference manual and user's guide: software for ordination, version 5.0. Microcomputer Power, Ithaca, USA, $496 \mathrm{pp}$.

Ter Steege, H., Pitman, N., Sabatier, D., Castellanos, H., Vander Hout, P., Daly, D.C., Silveira, M., Phillips, O.L., Vasquez,R., Van Andel, T., Duivenvoorden, J., De Oliveira,A.A., Ek, R., Lilwah, R., Thomas, R., Van Essen, J., Baider,C., Maas, P., Mori, S., Terborgh, J., Núñez, P.V., Mogollón,H. and Morawetz, W. 2003. A spatial model of tree adiversityand b-density for the Amazon Region. Biodiversityand Conservation, 12, 22552277.

Wittmann, F.,Anhuf, D. and Junk, W.J., 2002. Tree species distribution and community structure of central Amazonian várzea forests by remote sense techniques. J. Trop. Ecol., 18, pp. 805-820

Wittmann F., Schöngart J., Montero J. C., Motzer T., Junk W. J, Piedade M. T. F., Queiroz H. L. Worbes M., 2006a. Tree species composition and diversitygradients in white-water forests acrossthe Amazon Basin. Journal of Biogeography 33, 1334-1347. 
Wittmann, F., Schöngart, J., Parolin, P., Worbes, M., Piedade, M. T., \& Junk, W. J. $2006 b$. Wood specific gravity of trees in Amazonian white-water forests in relation to flooding. IAWA Journal, 27(3), 255-268.

Wittmann, F., Zorzi, B. T., Tizianel, F. A. T., Urquiza, M. V. S., Faria, R. R., Sousa, N. M., Módena, E. S., Gamarra, R. M., and Rosa, A. L. M. 2008. Tree species composition, structure, and aboveground wood biomass of a riparian forest of the Lower Miranda River, southern Pantanal, Brazil. Folia Geobotânica, 43(4), 397-411.

Wittmann, F.2012.Tree species composition and diversity in Brazilian freshwater floodplains. In Mycorrhiza: Occurrence in Natural and Restored Environments, Pagano MC (ed.). Nova Science Publishers: New York; 223-263.

Wittmann, F., Junk, W.J., Piedade, M.T.F., 2004. The várzea forests in Amazonia: flooding and the highly dynamic geomorphology interact with natural forest succession Forest Ecol. Manag., 196, pp. 199-212

Wittmann, F., Schöngart, J., Junk, W.J., 2010. Phytogeography, species diversity, community structure and dynamics of central Amazonian floodplain forests. In Amazonian Floodplain Forests: Ecophysiology, Biodiversity and Sustainable Management, Junk W., J., Piedade M., T., F., Wittmann F.,Schöngart J.,Parolin P. (eds). Ecological Studies 210, Springer Verlag: Berlin/Heidelberg/New York; 61-102.

Wittmann, F., Householder, E., Piedade, M.T.F., De Assis, R.L., Schöngart, J., Parolin, P., Junk, W.J.2013.Habitat specifity, endemism and the neotropical distribution of Amazonian white-water floodplain trees.Ecography 36, 690-707.

Worbes, M., 1985.Structural and other adaptation to long term flooding by trees in Central Amazonia.Amazoniana 9: 459-484.

Worbes, M., 1997.The forest ecosystem of the floodplains. In: Junk W., (Ed.), The Central Amazon Floodplain: Ecology of a Pulsating System. Ecological Studies, vol. 126. Springer. Zanne, A.E, Lopez-Gonzalez, G., Coomes, D.A, Ilic, J., Jansen, S., Lewis, S.L., Miller, R.B., Swenson, N.G., Wiemann, M.C., Chave, J., 2009. Data from: Towards a worldwide wood economics spectrum. Dryad Digital Repository. 


\section{Chapter 3}

\section{Stand dynamics of the drought-affected floodplain forests of Araguaia River, Brazilian Amazon}

Jürgen Homeier, Dariusz Kurzatkowski \& Christoph Leuschner

Acceptedby Forest Ecosystems 


\section{Abstract}

The floodplain forests of Araguaia River, a clear-water river in the southeastern Amazon (Tocantins State, Brazil), are characterized by seasonal flooding up to $3.5 \mathrm{~m}$ height, low nutrient levels in the water, and seasonal drought periods of 4-5 months. We studied the forest dynamics (tree diameter growth, tree mortality and recruitment) of this unique forest ecosystem over a 5-yr period by repeated censuses in 12 permanent plots established along a flooding gradient. The cumulative basal area in the plots increased by $0.84( \pm 0.45) \mathrm{m}^{2}$ ha $^{-}$ ${ }^{1} \mathrm{yr}^{-1}$ (mean $\pm \mathrm{SD}$ ) in the annually-flooded (AF) plots in lower terrain and by $0.69( \pm 1.00)$ $\mathrm{m}^{2} \mathrm{ha}^{-1} \mathrm{yr}^{-1}$ in the highernon-annually flooded (NAF) plots, corresponding to an aboveground biomass increase of $0.81( \pm 0.57)$ and $0.69( \pm 1.58) \mathrm{Mg} \mathrm{ha}^{-1} \mathrm{yr}^{-1}$ in the AF and NAF plots, indicating a recent carbon sink in the biomass. Mean diameter growth rate was $1.8( \pm 0.44) \mathrm{mm} \mathrm{yr}^{-1}$ in the AF and $2.0( \pm 0.56) \mathrm{mm} \mathrm{yr}^{-1}$ in the NAF plots (corresponding to a coarse wood production of $1.53( \pm 1.29)$ and $\left.2.02( \pm 0.52) \mathrm{Mg} \mathrm{ha}^{-1} \mathrm{yr}^{-1}\right)$, indicating no flooding effect on radial growth. Mean mortality rates in the 5-yr period were $1.9( \pm 0.37) \%$ $\mathrm{yr}^{-1}$ in the AF plots and $1.8( \pm 0.87) \% \mathrm{yr}^{-1}$ in the NAF plots with no differences along the flooding gradient. Highest mortalities were registered in the AF plots for the $10-20 \mathrm{~cm} \mathrm{dbh}$ class $\left(2.4 \% \mathrm{yr}^{-1}\right)$, likely as a consequence of flooding, and in the NAF plots for the $40-50 \mathrm{~cm}$ class $\left(3.0 \% \mathrm{yr}^{-1}\right)$, probably mainly caused by ENSO-related droughts. We conclude that these drought-affected tropical floodplain forests have a lower standing biomass and aboveground productivity than central Amazonian floodplain forests in more humid climates, and the imprint of the flooding gradient on stand dynamics is relatively weak, which may result from the lower flooding height and the interaction of flooding with low nutrient supply and periodic drought.

\section{Keywords :}

Amazon, diameter growth, dry season, flooding regime, mortality rate, productivity, tree recruitment 


\subsection{Introduction}

Amazonian freshwater floodplains cover an area of approximately 1.7 million $\mathrm{km}^{2}$ (Junk et al. 2011) and the majority of these wetlands are forested (Schöngart et al. 2010; Wittmann et al. 2010; Wittmann et al. 2013). Many ecological processes in these unique semi-aquatic woodlands, such as nutrient cycling, decomposition and forest succession, are heavily influenced by the flood pulse, and plant species inhabiting these environments have developed specific morpho-anatomical and physiological adaptations to cope with the seasonal flooding (Parolin et al. 2004; Junk 1989). The variable flooding regime and differences in water and sediment chemistry determine tree species composition and forest dynamics in these systems (Junk et al. 1989; Rosales et al. 1999; Wittmann et al. 2010; Junk et al. 2010; Junk et al. 2011).

Forests inundated seasonally by black- or clear-water rivers are collectively known as igapó and cover ca. $180000 \mathrm{~km}^{2}$ of the Amazon Basin (Melack and Hess 2010). These rivers (e.g. Rio Negro, Tapajós, Tocantins and Araguaia) originate in Precambrian formations, notably the Guiana Shield and Central Brazilian Shield, with deeply weathered soils and thus carry black water and clear water, respectively (Irion et al. 2010), with a reduced load of suspended inorganic compounds compared to white-water rivers. The fertility of igapó floodplains is therefore much lower than that of floodplains which are inundated by sediment-rich white water rivers (várzea floodplains).

The Araguaia floodplain covers the vast area of $58600 \mathrm{~km}^{2}$ in the southeast of the Amazon Basin (Melack and Hess 2010) and includes Bananal Island, the world's largest fluvial island. This extended semi-aquatic landscape represents the fifth largest floodplain area in South America. Araguaia River is a clear-water river with large tracts of igapó (Junk et al. 2011). The region is localized in the transition zone from the Amazonian moist lowland forest to the semi-humid to semi-arid Brazilian cerrado forest, two biomes with very high tree species richness. While the immediate study region is still covered by large tracts of natural forest vegetation well-preserved in Cantão State Park, the greater Araguaia floodplain is part of the so-called 'Arc of deforestation' in southern Amazonia which is under heavy pressure by human expansion. 
The forests in the study region are exposed to seasonal flood levels of up to $3.5 \mathrm{~m}$ height, corresponding to a submersion of the trees for up to 150 days per year. In this part of Amazonia with an extended dry season, the floodplain forest is not only exposed to longlasting inundation but also to seasonal drought. Thus, the river banks in the transition from high to low terrain are characterized by two opposing stress gradients, increasing anoxia in direction of the river during the flooding season, and decreasing drought exposure in the dry season. We expected that the combination of these two stressors (i) has a negative effect on forest productivity and standing biomass, and (ii) represents an effective environmental filter, which largely determines the species composition of the floodplain forests at different heights on the river banks. In support of our first assumption, a biomass inventory found that canopy height and aboveground live tree biomass (AGB) are indeed lower in the Araguaia floodplain forest than in the less seasonal floodplain forests of the central Amazon (Kurzatkowski et al. 2015).

In the present study, we measured tree radial growth and wood production and analyzed stand dynamics (tree mortality and recruitment) in the same plots along a flooding gradient in the Araguaia floodplain over a period of five years. We further expected (iii) that a higher flood level and longer inundation at the lowest sites should cause elevated tree turnover rates (greater mortality and also recruitment rates), while greater drought exposure at the highest sites should increase mortality at this end of the gradient as well but not recruitment. Our studies in this seasonally-dry tropical floodplain forest are among the first to analyze the dynamics of these unique forests. In the absence of comparable studies, we contrast our results with findings from floodplain forests in humid regions of Amazonia.

\subsection{Methods}

\subsubsection{Study area}

The study was conducted in the southern part of Cantão State Park in the south-eastern Brazilian Amazon on the Araguaia river floodplain (Eiten 1985), that was already established in 1989. The region is located in Tocantins State, Brazil, in the transition zone between the Amazon forests in the west and the cerrado in the east (Figure 1). It is covered by large areas of intact moist forest and patches of cerrado on drier soil. 
The soils of the study sites are quite variable ranging from upland red-yellow and yellow Oxisols and red-yellow Ultisols to alluvial soils with hydromorphic lateritic and gleyic characteristics (DNPM 1978). The soils on the floodplain are acid and nutrient-poor Dystrophic Plinthosols and Gleysols (Martins and Kardec 2006).

The region has a hot, semi-humid tropical seasonal climate with $1755 \mathrm{~mm}$ average annual precipitation (Kurzatkowski et al. 2015). The rainy period lasts from November to April/May, followed by a distinct dry season from May/June to September with monthly precipitation totals of $50 \mathrm{~mm}$ or less in these four to five months. Mean annual temperature is $26^{\circ} \mathrm{C}$; the hottest months are August and September with means of $30^{\circ} \mathrm{C}$, the coolest month is July $\left(22^{\circ} \mathrm{C}\right)$. There is a strong interanual variability in the total amount and distribution of precipitation, and the year 2005 was particularly dry (Borma et al. 2009).

\subsubsection{Study plots}

Twelve permanent plots of 0.25 ha size $(50 \mathrm{~m} \times 50 \mathrm{~m})$ were established in 2001 for studying forest dynamics processes in relation to variation in flood level height. The study plots are located on the right bank of Javaés River, a tributary of Araguaia river, in vicinity to Canguçu Research Center (958’41’S, 5002’12’W) (Figure 1).

The plots represent a gradient of flood levels and flooding duration with distances to Javaés River varying between 0.1 and $1.0 \mathrm{~km}$. The distance between soil surface and the upper limit of the dark water mark visible on the tree trunks was used to define the maximum flood level in a plot. All plots were selected in forest areas without larger recent canopy gaps, thus avoiding patches with major disturbance or covered by early-successional stages.

The 12 plots were assigned to two groups differing in flood level height (Kurzatkowski et al. 2015). In annually flooded (AF) stands $(n=5)$, flooding occurred every year, reaching maximum water heights of 1.5 to $3.5 \mathrm{~m}$ with inundation lasting for two to five months. The second group contains non-annually flooded (NAF) stands $(n=7)$ with inundation occurring only irregularly for periods of up to 2 months; flood levels reached only $1.3 \mathrm{~m}$ at the most. 


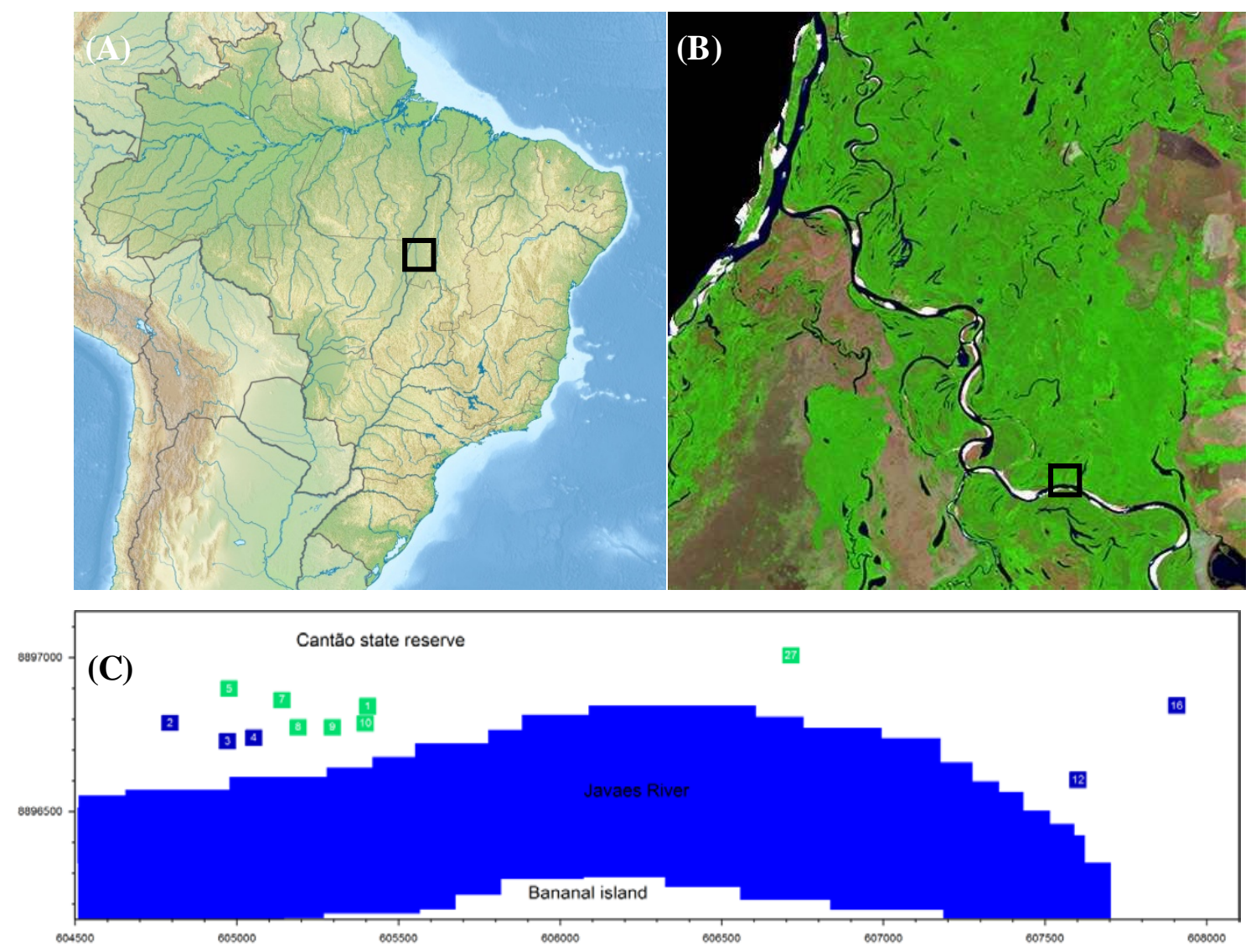

Figure 1.(A, B) Location of the study area in Brazil (Brasil Visto do Espaço, http:/www.cdbrasil.cnpm.embrapa.br) and (C) the distribution of plots along the Javaes river in the Cantão State Reserve, Tocantins, Brazil. Dark squares represent annually flooded plots (AF) and clear squares non-annually flooded plots (NAF).

\subsubsection{Data collection and analysis}

A census of the tree populations in all plots was conducted in 2001 and repeated in 2006. The diameter at breast height ( $\mathrm{dbh}$ ) of all living trees with $\mathrm{dbh} \geq 5 \mathrm{~cm}$ was recorded at 1.3 m. Diameters of buttressed trees were measured immediately above the buttresses to avoid overestimation (Condit 1998). Tree heights were measured with a telescope pole of $15 \mathrm{~m}$ length; the heights of taller trees were estimated. Palms and lianas were not included in the inventory. Tree species identification was conducted by a local field assistant with 
knowledge of the tree flora. In addition, plant samples were collected and compared to herbarium collections at the Federal University of Tocantins in Palmas. Phylogenetic classification is based on Angiosperm Phylogeny Group III (AGP III, 2009). The scientific species names were checked in the Tropicos database (www.tropicos.org).

Following Bellingham and Sparrow (2009) we calculated annual rates of tree recruitment and mortality. The annualized tree mortality rate (M; in \%) was derived from the expression:

$\mathrm{M}=100 *\left(1-\left(1-\left(\mathrm{N}_{1}-\mathrm{N}_{\mathrm{S}}\right) / \mathrm{N}_{1}\right)^{1 / t}\right)$,

where $\mathrm{N}_{1}$ is the number of individuals in the first census, $\mathrm{N}_{\mathrm{S}}$ is the number of surviving individuals (excluding new recruits) in the second census, and $t$ is the time in years. The annualized tree recruitment rate (R; in \%) was calculated as:

$\mathrm{R}=100 *\left(1-\left(1-\mathrm{N}_{\mathrm{R}} / \mathrm{N}_{2}\right)^{1 / t}\right)$,

where $N_{R}$ is the number of recruited trees (all trees that reached the $5 \mathrm{~cm}$ dbh threshold between 2001 and 2006) between censuses, and $N_{2}$ is the total number of live individuals (including new recruits) in the second census.

Upright standing stems were considered dead, if their inner bark was dry and easily separated from the sapwood. For the 12 most common tree species on our plots, the rates of recruitment and mortality were also analyzed separately.

To estimate aboveground coarse woody biomass (AGB), we applied the allometric equation for tropical wet forests proposed by Chave et al. (2005), with wood specific gravity (WSG), dbh and tree height as parameters. WSG data for the tree species were obtained from the Global Wood Density Database (http//datadryad.org/handle/10255/dryad.235) (Zanne et al. 2009; Chave et al. 2009). In cases where species-specific information was missing, we used means of WSG calculated from the values of the species of the same genus. For not identified trees we used the average of WSD of the respective plot. 
The aboveground coarse wood biomass production (WP) of all trees, which had survived in 2006, was calculated as the AGB difference between the censuses in 2006 and 2001. Means of parameters were compared with T-tests, using Statistica 12 (StatSoft, Tulsa, OK, USA) and regression analyses were performed with Xact 8.0 software (SciLab, Hamburg, Germany).

Due to the avoidance of larger recent gaps or patches with early regrowth, we expect our AGB estimates to be in the upper range of forest biomass figures. On the other hand, our selection criteria should result in below-average tree growth rates and WP rates. 


\subsection{Results}

\subsubsection{Forest structure, coarse wood production and forest dynamics}

In the surveyed area of the 12 plots (3 ha in total) in the Araguaia floodplain forest, average stem density $(\mathrm{dbh} \geq 5 \mathrm{~cm})$ in 2001 was $1005( \pm 155)$ (mean $\pm \mathrm{SD}) \mathrm{ha}^{-1}$ in the NAF plots and $1182( \pm 367) \mathrm{ha}^{-1}$ in the AF plots (Table 1).

Table 1 Maximum flood levels and changes in stem density, biomass and growth for all permanent plots

\begin{tabular}{|c|c|c|c|c|c|c|c|}
\hline $\begin{array}{l}\text { Forest } \\
\text { type }\end{array}$ & $\begin{array}{l}\text { Max. } \\
\text { flooding } \\
\text { level } \\
(\mathrm{cm})\end{array}$ & $\begin{array}{l}\text { Stem } \\
\text { density } 2001 \\
\left(\mathrm{ha}^{-1}\right)\end{array}$ & $\begin{array}{l}\text { Dead } \\
\text { trees } \\
\left(\mathrm{ha}^{-1}\right)\end{array}$ & $\begin{array}{l}\text { Recruited } \\
\text { trees (ha } \\
\text { 1) }\end{array}$ & $\begin{array}{l}\text { Basal area } \\
\text { change }\left(\mathrm{m}^{2}\right. \\
\left.\mathrm{ha}^{-1} \mathrm{yr}^{-1}\right)\end{array}$ & $\begin{array}{l}\text { Mean } \\
\text { diameter } \\
\text { growth } \\
\left.(\mathrm{mm} \mathrm{yr})^{-1}\right)\end{array}$ & $\begin{array}{l}\text { Biomass } \\
\text { change (Mg } \\
\text { ha }^{-1} \mathrm{yr}^{-1} \text { ) }\end{array}$ \\
\hline NAF & 85 & 1068 & 144 & 92 & -0.75 & 1.5 & -1.21 \\
\hline NAF & 90 & 1220 & 136 & 92 & 1.20 & 2.4 & 1.99 \\
\hline NAF & 90 & 1024 & 44 & 96 & 1.01 & 1.8 & 0.75 \\
\hline NAF & 90 & 1084 & 84 & 112 & 1.82 & 2.0 & 2.76 \\
\hline NAF & 95 & 784 & 68 & 40 & 0.33 & 1.6 & 1.11 \\
\hline NAF & 100 & 1044 & 32 & 84 & 1.64 & 1.7 & 2.15 \\
\hline NAF & 130 & 812 & 104 & 152 & -0.45 & 3.1 & -1.18 \\
\hline Average & $97( \pm 15)$ & $1005( \pm 115)$ & $88( \pm 43)$ & $95( \pm 33)$ & $0.69( \pm 1.00)$ & $\begin{array}{l}2.0 \\
( \pm 0.56)\end{array}$ & $0.69( \pm 1.58)$ \\
\hline $\mathrm{AF}$ & 150 & 1040 & 80 & 112 & 1.10 & 2.1 & 1.31 \\
\hline AF & 200 & 952 & 88 & 140 & 1.18 & 2.5 & 1.56 \\
\hline AF & 320 & 996 & 104 & 56 & 0.10 & 1.6 & 0.07 \\
\hline$A F$ & 330 & 1832 & 120 & 84 & 1.09 & 1.4 & 1.06 \\
\hline$A F$ & 350 & 1092 & 136 & 84 & 0.73 & 1.7 & 1.05 \\
\hline Average & $270( \pm 89)$ & $1182( \pm 367)$ & $\begin{array}{l}106 \\
( \pm 21)\end{array}$ & $95( \pm 32)$ & $0.84( \pm 0.45)$ & $\begin{array}{l}1.8 \\
( \pm 0.44)\end{array}$ & $0.81( \pm 0.57)$ \\
\hline
\end{tabular}

During the 5-yr study period, we registered only marginal changes in stem density, as no major disturbance event apart from drought occurred. Stem density increased to $1007( \pm 157)$ $\mathrm{ha}^{-1}$ in the NAF plots and decreased to $1180( \pm 361) \mathrm{ha}^{-1}$ in the AF plots. In 2001, basal area and tree aboveground biomass (AGB) means of $20.9( \pm 3.4) \mathrm{m}^{2} \mathrm{ha}^{-1}$ and $146.6( \pm 43.9) \mathrm{Mg}$ $\mathrm{ha}^{-1}$ werecalculatedfor the NAF plots, while $17.1( \pm 2.4) \mathrm{m}^{2} \mathrm{ha}^{-1}$ and $100.5( \pm 20.3) \mathrm{Mg} \mathrm{ha}^{-1}$ were recorded in the AF plots, respectively. 
Maximum flood levels and changes in stem density, biomass and growth in the 12 permanent plots between 2001 and 2006. Also given are the averages ( \pm SD) for nonannually flooded forest (NAF) and for annually flooded forest (AF) which show no significant differences.

The cumulative basal area in the plots increased by $0.84( \pm 0.45)$ and $0.69( \pm 1.00) \mathrm{m}^{2} \mathrm{ha}^{-1} \mathrm{yr}^{-}$ ${ }^{1}$ in the AF and NAF plots, corresponding to an AGB increase of $0.81( \pm 0.57) \mathrm{Mg} \mathrm{ha}^{-1} \mathrm{yr}^{-1}$ in the AF plots and $0.69( \pm 1.58) \mathrm{Mg} \mathrm{ha}^{-1} \mathrm{yr}^{-1}$ in the NAF plots. The surviving trees had a mean diameter growth of $1.8( \pm 0.44)$ (AF plots) and $2.0( \pm 0.56) \mathrm{mm} \mathrm{yr}^{-1}$ (NAF plots) in the five years, summing up to a coarse wood production (WP) of $1.53( \pm 0.20)$ in the AF plots and $2.02( \pm 0.52) \mathrm{Mg} \mathrm{ha}^{-1} \mathrm{yr}^{-1}$ in the NAF plots during the period 2001-2006 (Figure 2). 


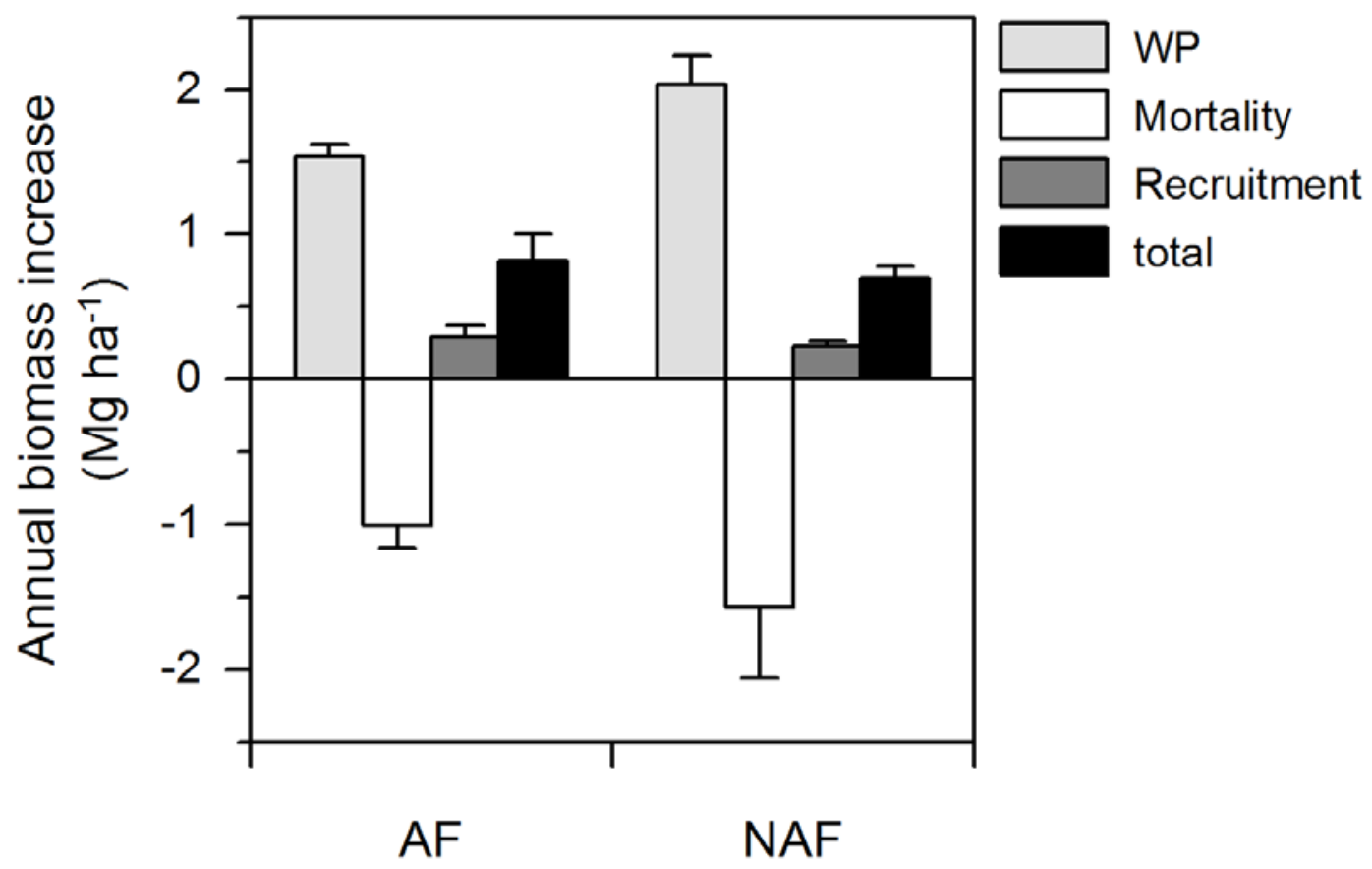

Figure 2.Fractions of biomass of trees with $\mathrm{dbh} \geq 5 \mathrm{~cm}$ in annually flooded forest (AF; five plots) and non-annually flooded forest (NAF; seven plots) during the study period from 2001-2006. Shown are means ( \pm SE) of coarse wood production (WP), production of dead tree mass (mortality), tree recruitment and the net change in live biomass (total; WP + recruitment - mortality). The two forest types show no significant differences. 
Mean tree mortality rates in the 5-yr period were $1.9 \%$ in the AF plots and $1.8 \%$ in the NAF plots, corresponding to a dead wood production of $1.01( \pm 0.34)$ and $1.57( \pm 1.29) \mathrm{Mg} \mathrm{ha}^{-1} \mathrm{yr}^{-}$ ${ }^{1}$. Highest mortality rates were registered in the AF plots for the $10-20 \mathrm{~cm}$ dbh class with $2.4 \%$, and in the NAF plots for the $40-50 \mathrm{~cm}$ class (3.0\%, Figure 3 ).

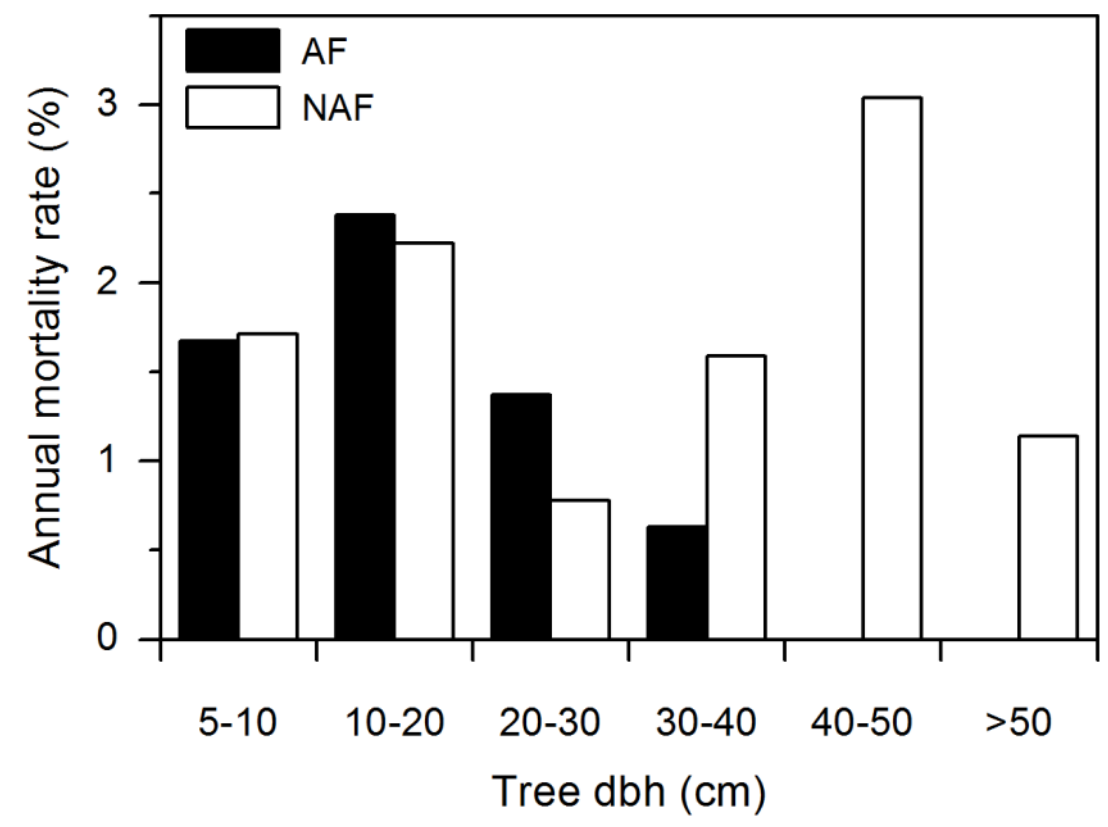

Figure 3.Annual tree mortality rates in different diameter classes in the two forest categories AF (annually flooded, black bars) and NAF (non-annually flooded, white bars) during the study period from 2001-2006. Of the 3224 stems registered in 2001 (AF: 1465, NAF: 1759) 285 died during the five years period until 2006 (AF: 132, NAF: 153).

The mean recruitment rates were $1.8 \%$ in the AF plots and $2.0 \%$ in the NAF plots, resulting in a mean ingrowth of $0.29( \pm 0.17)$ in the AF plots and $0.23( \pm 0.09) \mathrm{Mg} \mathrm{ha}^{-1} \mathrm{yr}^{-1}$ in the NAF plots.

None of the means of aboveground coarse wood production $(\mathrm{p}=0.06)$, mortality $(\mathrm{p}=0.37)$ and recruitment $(\mathrm{p}=0.39)$ differed significantly at $\mathrm{p}<0.05$ between the two forest types. Neither mortality nor recruitment rate showed significant linear correlations with the maximum flood level height observed in the study plots (Figure 4). 

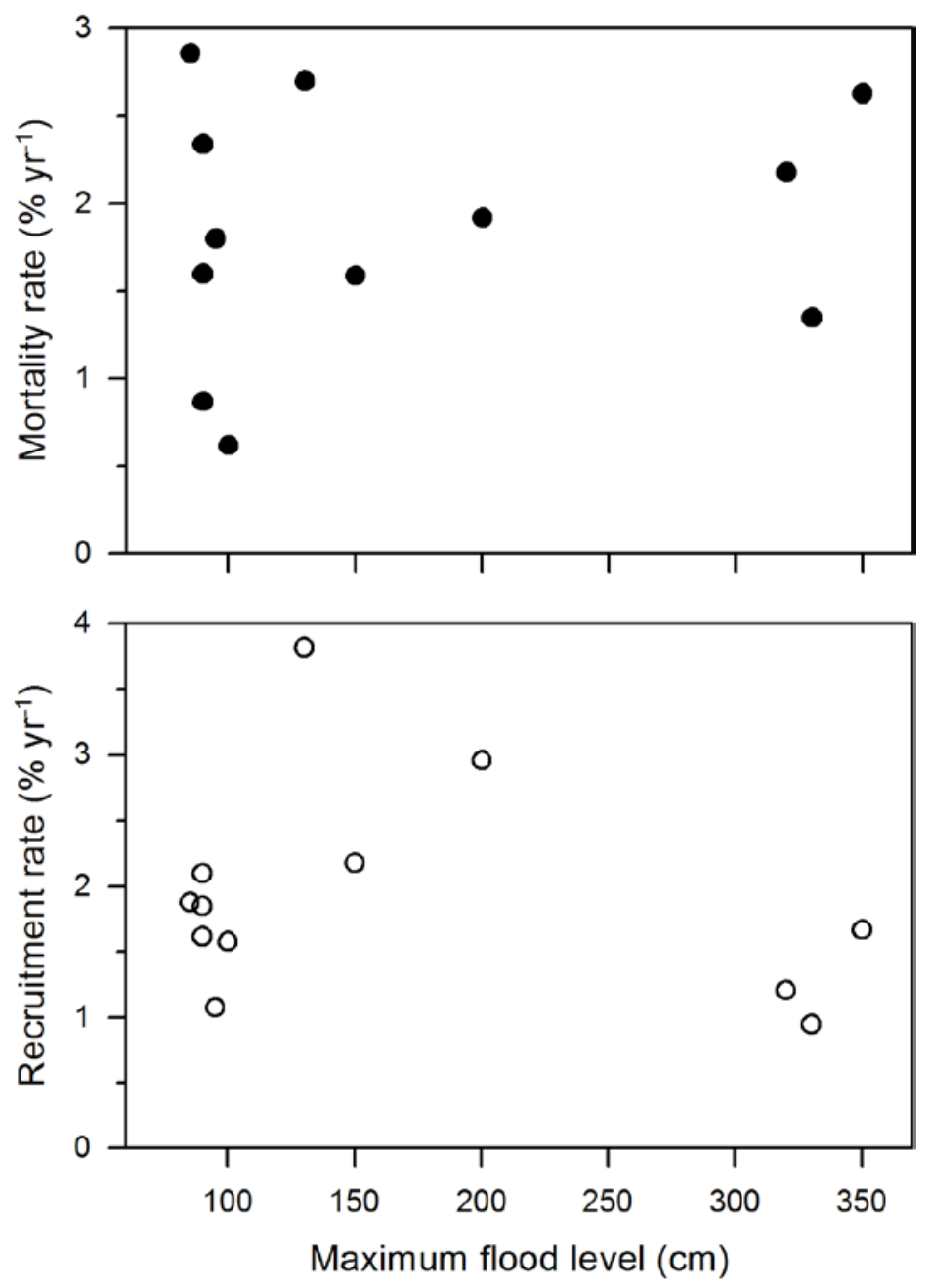

Figure 4.Annual tree mortality rate (a) and annual tree recruitment rate (b) in relation to the maximum flooding level of the study plots. None of the relations were significant at $\mathrm{p}<0.05$.

\subsubsection{Population dynamics of selected species}

The 12 most abundant tree species in the study plots, all present with stem densities $>15 \mathrm{ha}^{-}$ ${ }^{1}$, were included in a species-specific demographic analysis (Table 2). The most frequently occurring species in the AF plots (all with more than 147 stems ha $^{-1}$ ) were Alibertia edulis, Inga marginata and Mouriri guainensis and in theNAF plots ( $>91$ stems ha ${ }^{-1}$ ) Protium heptaphyllum, Brosimum rubescens and Protium paniculatum. 
Table 2:Stem density (for the year 2001), annual mortality and recruitment rates, and annual diameter growth for the 12 most abundant tree species in the NAF and AF study plots during the study period (2001 - 2006).

\begin{tabular}{|c|c|c|c|c|c|c|c|c|}
\hline \multirow[b]{2}{*}{ Species } & \multicolumn{2}{|c|}{$\begin{array}{l}\text { Stem density } \\
\left(\mathrm{ha}^{-1}\right)\end{array}$} & \multicolumn{2}{|c|}{$\begin{array}{l}\text { Mortality rate } \\
\left(\% \mathrm{yr}^{-1}\right)\end{array}$} & \multicolumn{2}{|c|}{$\begin{array}{l}\text { Recruitment rate } \\
\left(\% \mathrm{yr}^{-1}\right)\end{array}$} & \multicolumn{2}{|c|}{$\begin{array}{l}\text { Mean diameter } \\
\text { growth }\left(\mathrm{mm} \mathrm{yr}^{-1}\right)\end{array}$} \\
\hline & NAF & AF & NAF & AF & NAF & AF & NAF & AF \\
\hline $\begin{array}{l}\text { Albizia } \\
\text { hasslerii }\end{array}$ & 40 & 20 & 2.09 & 0.81 & 2.64 & 0.81 & 1.54 & 1.48 \\
\hline $\begin{array}{l}\text { Alibertia } \\
\text { edulis }\end{array}$ & 4 & 258 & 0 & 1.21 & 0 & 0.77 & 1.70 & 1.35 \\
\hline $\begin{array}{l}\text { Brosimum } \\
\text { rubescens }\end{array}$ & 101 & 39 & 1.52 & 0.83 & 1.52 & 0.42 & 1.50 & 1.35 \\
\hline $\begin{array}{l}\text { Combretum } \\
\text { leprosum }\end{array}$ & 37 & 35 & 2.59 & 9.31 & 2.59 & 7.09 & 1.33 & 1.54 \\
\hline $\begin{array}{l}\text { Cordia } \\
\text { sellowiana }\end{array}$ & 46 & 0 & 1.75 & & 1.75 & & 1.23 & - \\
\hline $\begin{array}{l}\text { Inga } \\
\text { marginata }\end{array}$ & 63 & 208 & 2.26 & 1.10 & 3.12 & 0.95 & 2.02 & 1.30 \\
\hline $\begin{array}{l}\text { Mouriri } \\
\text { guianensis }\end{array}$ & 78 & 147 & 1.52 & 2.28 & 1.66 & 1.62 & 1.52 & 1.46 \\
\hline $\begin{array}{l}\text { Piranhea } \\
\text { trifoliata }\end{array}$ & 13 & 87 & 1.89 & 0.37 & 0 & 0 & 1.57 & 1.52 \\
\hline $\begin{array}{l}\text { Protium } \\
\text { heptaphyllum }\end{array}$ & 309 & 94 & 2.12 & 3.48 & 1.87 & 3.97 & 1.24 & 1.93 \\
\hline $\begin{array}{l}\text { Protium } \\
\text { paniculatum }\end{array}$ & 91 & 6 & 1.81 & 21.40 & 1.69 & 22.88 & 1.49 & 1.67 \\
\hline $\begin{array}{l}\text { Saccellium } \\
\text { brasiliense }\end{array}$ & 5 & 101 & 0 & 1.64 & 0 & 1.48 & 1.69 & 1.24 \\
\hline $\begin{array}{l}\text { Xylopia } \\
\text { frutescens }\end{array}$ & 51 & 34 & 2.11 & 4.47 & 3.38 & 8.31 & 2.44 & 1.97 \\
\hline
\end{tabular}

While 11 of the 12 species occurred in both forest types and could be compared with respect to flooding tolerance, Cordia sellowiana was abundant in the NAF plots but completely absent from the AF plots. Alibertia edulis, Piranhea trifoliate and Saccellium brasiliense had significantly higher densities in the AF plots, whereas Protium heptaphyllum was more common in the NAF plots. 
Average annual mortality and recruitment of the 12 species during the 5-yr study period varied markedly between species and forest types. The highest annual mortality rates in the NAF plots were observed for Combretum leprosum, Inga marginata, Protium heptaphyllum and Xylopia frutescens (2.1-2.6\%). In the annually flooded plots, the species with highest mortality rates were Protium paniculatum, Combretum leprosum, Xylopia frutescens and Protium heptaphyllum (3.5-21.4\%). The same four tree species with highest mortality had also the largest recruitment rates in the AF plots (4.0-22.9\%).

When the tree species were grouped by their forest type preference (Figure 5), the five AF species showed almost no differences in dynamic properties between forest types; they had slightly higher mortality rates than recruitment rates in both forest types. In contrast, the seven NAF species had higher recruitment than mortality rates in both forest types. The average recruitment rates as well as the mortality rates of the latter species were conspicuously higher in the AF plots than in the NAF plots.

Mean stem diameter growth rates typically varied between 1.23 and $1.97 \mathrm{~mm} \mathrm{yr}^{-1}$ in the AF and NAF plots and were relatively uniform among the species (Table 2). Particularly high growth rates were recorded in both forest types for the pioneer tree Xylopia frutescens (1.94

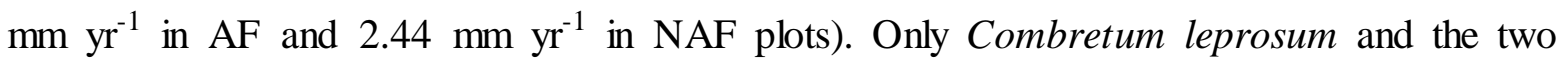
Protium species showed higher growth rates in the AF than in the NAF plots. 


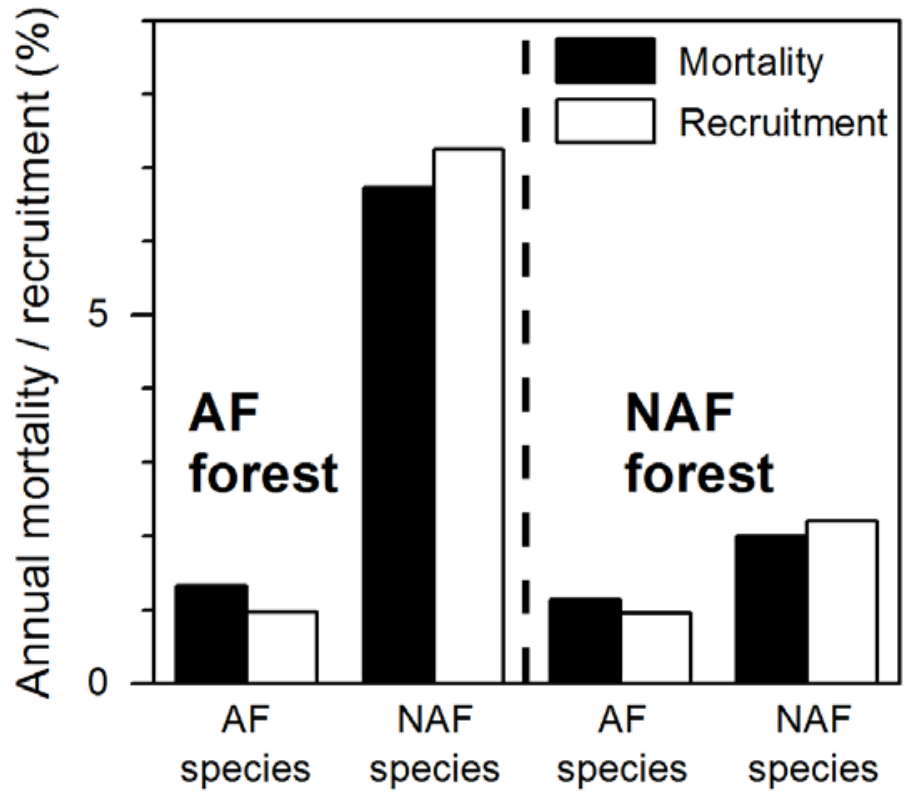

Figure 5.Mean annual mortality and recruitment rates of the twelve common tree species (see Table 2) in the AF and NAF plots. The species are categorized according to their forest type preference into AF-species (Alibertia edulis, Inga marginata, Mouriri guianensis, Piranhea trifoliata and Saccelium brasiliense) and NAF-species (Albizia hassleri, Brosimum rubescens, Combretum leprosum, Cordia sellowiana, Protium heptaphyllum, Protium paniculatum and Xylopia frutescens). 


\subsection{Discussion}

The two stand inventories in 2001 and 2006 produced the unexpected result that mean stem diameter growth was very similar in the annually-flooded and non-annually flooded plots (1.8 and $2.0 \mathrm{~mm} \mathrm{yr}^{-1}$ ) and thus apparently independent of flooding height and duration. Cumulative basal area in the plots increased on average by $0.69 \mathrm{~m}^{2} \mathrm{ha}^{-1} \mathrm{yr}^{-1}$ in the NAF plots, and by even $0.84 \mathrm{~m}^{2} \mathrm{ha}^{-1} \mathrm{yr}^{-1}$ in the AF plots (difference not significant). This related to an average aboveground biomass increase of 2.02 and $1.53 \mathrm{Mg} \mathrm{ha}^{-1} \mathrm{yr}^{-1}$ in the NAF and AF plots. As with stem radial growth, aboveground productivity apparently was not reduced by higher and longer flooding. This matches the biomass inventory data, which also showed no effect of flood height and duration on the standing aboveground biomass stocks (Kurzatowski et al. 2015).

The apparently low effect of flooding height and duration on tree diameter growth in our plots comes as a surprise. Other studies found a negative relation between diameter growth and the height and duration of annual inundations, e.g. in the igapó forests along Rio Negro (Schöngart et al. 2010), Amazonian várzea forests (Nebel et al. 2001; Schöngart et al. 2010) and riparian forests in the Brazilian Pantanal (Wittmann et al. 2008; Schöngart et al. 2011). Worbes (1997) confirmed with dendrochronological methods that the floodplain trees typically reduce wood growth during the aquatic phase and then remain in a state of cambial dormancy. Flooding height and duration perhaps were in the Araguaia system not as extreme as in other floodplain studies, where closed forest occurs up to inundation depths of $9 \mathrm{~m}$ (black water rivers) or $7.5 \mathrm{~m}$ (white water rivers) (Junk et al. 2011). In addition, the relatively extreme environment (low fertility and seasonal drought) could have masked a flooding effect on cambial activity in this region.

In our study, a significant flooding effect was however detected on wood density, which increased significantly with increasing flood height and duration, and for maximum tree height of the stands, which decreased significantly in direction of the river. We interpret these relationships as a hint that the flooding regime and associated soil anoxia acted as an environmental filter selecting for more flood-tolerant tree species with higher wood density close to the river. The production of wood with higher density compensated for the smaller maximum tree height in the AF stands with the consequence that standing biomass and also 
biomass production were not lower than in the NAF plots. Thus, the productivity data suggest that higher wood density was not related to lower diameter growth in our species sample. With respect to the causes of these patterns, our dbh and tree height data suggest that the average AF tree must either be shorter-lived or grow slower in height than the average NAF tree. As trees with $\mathrm{dbh}>50 \mathrm{~cm}$ were more abundant in the NAF plots, we assume that the greater maximum tree height in these stands is a consequence of greater age and not intrinsically higher height growth rates. In two of the three highly flooded plots, the mortality rate in the five study years was indeed high with $>2 \% \mathrm{yr}^{-1}$, which may suggest that trees in the AF plots do no reach larger sizes and ages due to reduced survival under high floods.

Except for two plots, the net woody biomass change was positive in the period 2001-2006 in the AF and NAF plots, indicating that the Araguaia floodplain forests function currently as a carbon sink with a net storage of 0.81 and $0.69 \mathrm{Mg} \mathrm{ha}^{-1} \mathrm{yr}^{-1}$ in the AF and NAF plots. In secondary floodplain forests in humid Amazonia, Lucas et al. (2014) found an average net biomass increase of $6.4 \mathrm{Mg} \mathrm{ha}^{-1} \mathrm{yr}^{-1}$, for old-growth Amazonian forests Phillips et al. (2009) estimated a mean biomass increase for the trees with $\mathrm{dbh} \geq 10 \mathrm{~cm}$ of $0.90 \pm 0.66 \mathrm{Mg} \mathrm{ha}^{-1} \mathrm{yr}^{-}$ ${ }^{1}$. Baker et al. (2004) gave a mean long-term biomass increase for Amazonian lowland forests of of $1.21 \pm 0.43 \mathrm{Mg} \mathrm{ha}^{-1} \mathrm{yr}^{-1}$. This is slightly higher than our values, but may easily be explained by the more stressful conditions (more pronounced dry season combined with low nutrient availabilty) in the igapó floodplains and the lower canopy height. A long-term biomass increase in recent decades has also been found in other tropical forests, e.g. in those of Africa (Lewis et al. 2009), but studies reporting no biomass change in recent decades do also exist (Laurance et al. 2004; Chave et al. 2008). The causes of an apparent long-term forest biomass increase in the tropics are debated and refer to climate change or recovery from past disturbances (Chave et al. 2008; Clark 2002; Fisher et al. 2008, Körner 2006, Lewis et al. 2006, 2009; Wright 2005). Since we do not have soil carbon inventory data, it remains unclear whether the ecosystem $\mathrm{C}$ balance in Araguaia floodplain is also positive or not.

The Araguaia floodplain forest differs from other Amazonian igapó forests by its extended dry season which may represent an additional stressor for the trees. While plot-level tree 
diversity was not markedly lower than in central or western Amazonian várzea and igapó forests, mean stand-level basal area $\left(19.4 \mathrm{~m}^{2} \mathrm{ha}^{-1}\right)$ and aboveground biomass (117 $\mathrm{Mg} \mathrm{ha}^{-1}$ ) were markedly smaller than in other Neotropical floodplains, including the cerrado floodplains in Pantanal (biomass: 136 - $260 \mathrm{Mg} \mathrm{ha}^{-1}$; Schöngart et al. 2011). We speculate that the low biomass is caused by a combination of the low fertility of the clear waters of Araguaia river and the 4-5 months of dry season. While mean stem diameter growth was apparently not negatively affected by temporal water shortage in the NAF plots on higher terrain, we found a particularly high mortality rate, mostly of larger trees, in the highest NAF plots. A likely explanation is the extended drought in 2005 (Phillips et al. 2009), which may have killed several of the larger trees especially in the NAF plots. It appears that drought affected the AF plots less severely, probably because of the higher ground water level in the dry season. Even in non-flooded terra firme forests of moister tropical regions, diameter growth was found to be strongly related to the seasonality of precipitation (Brienen and Zuidema 2005) and severe droughts negatively affect forest dynamics, decreasing wood biomass productivity and increasing tree mortality (Phillips et al. 2009; Corlett et al. 2011; Lewis et al. 2011).

\subsubsection{Stand dynamics (recruitment and mortality)}

The mortality rates observed in our study (averages of $1.93 \% \mathrm{yr}^{-1}$ in the AF and $1.83 \% \mathrm{yr}^{-1}$ in the NAF plots) are comparable or lower than values reported from other floodplains in the Amazon (Brazil: 1.56-1.99\%, Campbell et al. 1992; Ecuador: 3.01, Korning and Balslev 1994; Peru: 1.79-3.16, Gentry and Terborgh 1990, Phillips et al. 1994, Nebel et al. 2001). In terra firmeforests near Manaus, Rankin de Merona et al. (1990) reported lower values of 1.13\% and Korning and Blaslev (1994) calculated values of 1.04-1.88\% for Ecuadorian terra firme forests. Elevated average mortality rates in floodplain forests as compared to terra firme stands are to be expected, but our record is too short to draw sound conclusions.

Highest mortality was observed in large trees (dbh class $>40-50 \mathrm{~cm}$ ) of the NAF plots on higher terrain. As large trees were hit most, we assume that the severe ENSO-related 2005 drought in the Amazon may have contributed to the elevated death rate (Condit et al. 2004, Williamson et al. 2000, van Nieuwstadt and Sheil 2005), as it has been reported by Philips et 
al. (2009) from other regions of the Amazon basin. The 2005 drought was also detected in the study region and resulted in strongly reduced soil moisture in the upper $2 \mathrm{~m}$ of soil during the dry season (Borma et al. 2009). In the course of climate change, Olivares et al. (2015) documented extended drought periods at the margins of the Amazon basin. While the growth response to climate change may be quite difficult to detect, increased mortality due to more severe droughts can have rapid and conspicuous effects on stand structure through the death of large trees. However, sampling over short observation periods as in our case may partly miss these events (Coomes et al. 2014).

\subsubsection{Tree species differences in growth and mortality}

Kubitzki (1989) assumed that many Amazonian floodplain tree species are ecotypes of taxa originating from the surrounding terra firme forests. When the species immigrate into the floodplains, they gradually develop adaptations to the periodic inundation. From the overall registered 54 tree species in the 12 plots, we classified 12 species by their habitat preference: seven could be categorized as species preferring the NAF forest due to higher stem densities here, and five as AF species. This suggests that the species differed in their degree of adaptation to this extreme environment. As an example of an AF species, Inga marginata had four times higher stem densitiesin the AF forest than in the NAF plots. This observation supports the assumption that this species colonizes low-lying, highly flooded river margins and uses the water for seed dispersion. However, this species likely has its ancestors not in the semi-deciduous drier forests of the south-eastern Amazon surrounding the Araguaia floodplain, but it probably has migrated along the large rivers from the central Amazon. Yet, other species likely have colonized the floodplain from the surrounding drier forests. For example, Protium heptaphyllum isan abundant species in semi-deciduous forests and the cerrado, which was three times more frequent in the NAF plots. Cordia sellowiana is a typical element of the Cerrado vegetation; it occurred exclusively in the NAF plots. This suggests that these species from higher terrain do not yet have developed adequate adaptations to the high flood levels in the AF plots or, alternatively, may physiologically not be capable of doing so because they have adapted to drought. However, the majority of species found in these floodplain forests seems to have closer relations to the more humid central Amazon. 
The species with NAF plot preference can indeed be considered as more flooding- sensitive, as their mortality rate was four times larger in the AF plots than that of the co-occurring $\mathrm{AF}$ species (Figure 5). In contrast, both tree categories had similar mortalities in the drier NAF plots. This indicates that the AF species are rarer in the drier NAF plots due to other reasons than a particularly high drought sensitivity. In fact, abundance in a plot, mortality rate and diameter growth in the two forest categories were in most species not related to each other (see Table 2). This excludes a simple ecophysiological explanation for the presence or absence of certain species along the flooding gradient.

While a decline in tree species richness with increasing flooding height and duration seems to be typical for many Amazonian floodplain forests (Terborgh and Andresen 1998, Nebel et al. 2001, Parolin et al. 2004), we found only a very slight (non-significant) increase in plotlevel species numbers from the AF to the NAF plots (Kurzatowski et al. 2015). The missing diversity gradient in the Araguaia floodplain may again be a consequence of the low nutrient concentration of the clear waters and the action of drought in this region.

In Central Amazonian floodplain forests, Worbes et al. (1992) found a clear differentiation of the average diameter growth rate among the dominant trees according to their successional status: pioneer species $\left(9.4 \mathrm{~mm} \mathrm{yr}^{-1}\right)>$ early-secondary species $\left(4.3 \mathrm{~mm} \mathrm{yr}^{-1}\right)>$ late-secondary species $\left(3.0 \mathrm{~mm} \mathrm{yr}^{-1}\right)>$ climax species $\left(2.0 \mathrm{~mm} \mathrm{yr}^{-1}\right)$. Our species had in most cases growth rates $<2 \mathrm{~mm} \mathrm{yr}^{-1}$. This, however, does not necessarily classify them all as climax species. Comparing the average diameter increment of three commercial tree species in igapó and várzea floodplain forests, Schöngart et al. (2005) measured significantly lower rates in the igapó forests, which may explain our relatively low rates.

The natural seasonal flood pulse is a critical mediator of tree regrowth, as floods facilitate seed dispersal, deposit sediments and promote the connectivity between different forest sites (Ward and Wiens 2001) which could enhance tree regeneration. However, we found no systematic difference in recruitment rates between AF and NAF plots, and for the 12 most abundant species no clear pattern emerged indicating a more successful offspring establishment in the plot category which was preferred by the adults. This suggests that 
other factors than flooding regime which affect seedling establishment and survival, must be equally important in our stands.

\subsection{Conclusions}

Our forest dynamics data from the seasonally-dry Araguaia floodplain show that the standing aboveground biomass and ANPP are relatively low compared to central Amazonian várzea floodplain forests, in support of our first assumption. In contrast to other Amazonian igapó and várzea floodplains, the flooding gradient imprinted only weakly on most standlevel structural and dynamic properties, while it influenced mean wood density and maximum stand height. As expected, tree mortality rates were relatively high in both annually and not-annually flooded plots, probably due to different causes. The high mortality observed in large NAF plot trees likely is a consequence of ENSO-related droughts which may threaten seasonally-dry floodplain forests at the edge of the Amazon more than in the humid regions of central Amazonia. Contrary to our expectation, we found no decrease in recruitment rate from low to high terrain suggesting that flooding is only one factor controlling tree regeneration in these floodplain forests. We conclude that the seasonally-dry floodplain forests of Araguaia are unique forest ecosystems which are at many places threatened by transformation. When intact they still seem to function as a net carbon sink, but this may change with increasing severity of climate warming-related droughts. 


\section{Funding}

This research was conducted as a component in the "Carbon Sequestration Project in Bananal Island" sponsored by AES Barry Foundation. DK received scholarships from CNPq (Brazilian National Council for Scientific and Technological Development) and from KAAD (Catholic Academic Exchange Service, Germany) which is gratefully acknowledged.

\section{Acknowledgements}

We are grateful for support to the Instituto Ecológica, Palmas, and the Federal University of Tocantins (UFT). We thank Antonio Morales for tree identification and numerous students from UFT for assistance with field work. 


\section{References}

Baker TR, Phillips OL, Malhi,Y, Almeida S, Arroyo L, Di Fiore A, Erwin T, Higuchi N, Killeen TJ, Laurance, SG, Laurance W F, Lewis SL, Monteagudo A, Neill DA, Vargas Nunez P, Pitman NCAN, Vasquez Martinez R (2004) Increasing biomass in Amazonian forest plots. P Roy Soc Lond B BioB 359: 353-365.

Bellingham PJ, Sparrow AD (2009) Multi-stemmed trees in montane rain forests: their frequency and demography in relation to elevation, soil nutrients and disturbance. J Ecol 97: 472-483.

Borma LDS, Da Rocha HR, Cabral OM, Von Randow C, Collicchio E, Kurzatkowski D, Brugger PJ, Freitas H, Tannus R, Oliveira L, Rennó CD, Artaxo P (2009) Atmosphere and hydrological controls of the evapotranspiration over a floodplain forest in the Bananal Island region, Amazonia. J. Geophys. Res. 114, G01003.

Brienen RJW, Zuidema PA (2005) Relating tree growth to rain-fall in Bolivian rain forests: a test for six species using tree ring analysis, Oecologia 146: 1-12.

Campbell DG, Stone, JL, Rosas A (1992) A comparison of the phytosociology and dynamics of three floodplain (Várzea) forests of known ages, Rio Juruá, western Brazilian Amazon. Bot J Linn Soc108(3): 213-237.

Chave J, Andalo C, Brown S, Cairns MA, Chambers JQ, Eamus D, Folster H, Fromard F, Higuchi N, Kira T, Lescure JP, Nelson BW, Ogawa H, Puig H, Riera B, Yamakura T, (2005) Tree allometry and improved estimation of carbon stocks and balance in tropical forests. Oecologia 145: 87-99

Chave J, Condit R, Muller-Landau H, Thomas S, Ashton P, Bunyavejchewin S, Co L, Dattaraja H, Davies S, Esufali S, Ewango C, Feeley K, Foster R, Gunatilleke N, Gunatilleke S, Hall P, Hart T, Hernandez C, Hubbell S, Itoh A, Kiratiprayoon S, LaFrankie J, Lao S, Makana J, Noor M, Rahman Kassim A, Samper C, Sukumar R, Suresh H, Tan S, Thompson J, Tongco M, Valencia R, Vallejo M, Villa G, Yamakura T, Zimmerman J, Losos E (2008) 
Assessing evidence for a pervasive alteration in tropical tree communities. PLoS Biology 6: e45.

Chave J, Coomes DA, Jansen S, Lewis SL, Swenson, NG, Zanne AE (2009) Towards a worldwide wood economics spectrum. Ecol Lett 12(4): 351-366.

Chaves M M, Maroco J P, Pereira J S (2003). Understanding plant responses to drought from genes to the whole plant. Funct Plant Biol 30:239-264.

Clark DA, Clark DB (1992) Life history diversity of canopy and emergent trees in a neotropical rainforest. Ecol Monographs62: 315-344.

Clark DA (2002) Are tropical forests an important carbon sink? Reanalysis of the long-term plot data. Ecol Appl 12: 3-7.

Condit RS, Aguilar A, Hernandez R, PerezS, LaoG, AngehrSP, Hubbell,Foster $\mathrm{RB}(2004)$ Tropical forest dynamics across a rainfall gradient and the impact of an El Nino dry season. J Trop Ecol20: 51-72

Condit R (1998) Tropical Forest Census Plots: Methods and Results from Barro Colorado Island, Panama and a Comparison with other Plots. Springer, Berlin.

Coomes DA, Burslem DF, Simonson WD (eds) (2014) Forests and Global Change Cambridge University Press.

Corlett RT (2011) Impact of warming on tropical lowland forests. Trends Ecol Evol 26: 606-613.

Departamento Nacional de Produção Mineral, DNPM (1978) Projecto RADAMBRASIL. Folha SC. 20 Porto Velho; geologia, geomorfologia, pedologia, vegetação e uso potencial da terra. Anexo: Analise estistitica de dados (Vegetacão). Departamento Nacional de Produção Mineral, Rio de Janeiro, Brazil.

Eiten G (1985) Vegetation near Santa Teresinha, NE Mato Grosso. Acta Amazônica 15 (3/4): 275301. 
Fisher JB, Tu KP, Baldocchi DD (2008) Global estimates of the land-atmosphere water flux based on monthly AVHRR and ISLSCP-II data, validated at 16 FLUXNET sites. Remote Sensing of Environment 112(3):901-919

Gatti L, Gloor M, Miller JB, Doughty CE, Malhi Y, Domingues LG et al. (2014) Drought sensitivity of Amazonian carbon balance revealed by atmospheric measurements. Nature506: 76-80.

Gentry AH, Terborgh J (1990) Composition and dynamics of the Cocha Cashu mature floodplain forest. In: Gentry, AH (Ed.), Four Neotropical Rainforests. Yale University Press, New Haven and London, pp. 542-563

Irion G, de Mello JASN, Morais J, Piedade MTF, Junk WJ, Garming L (2010) Development of the Amazon valley during the Middle to Late Quaternary: sedimento-logical and climatological observations. In: Junk WJ,Piedade, MTF, Wittmann F, Schöngart J, Parolin P (eds) Central Amazonian floodplain forests: ecophysiology, biodiversity and sustainable management, pp.27-42. Springer, Berlin.

Junk WJ (1989) Flood tolerance and tree distribution in central Amazonian floodplains. In: Holm-Nielsen LB, Nielsen IC, Balslev H (eds) Tropical Forests: Botanical Dynamics, Speciation and Diversity. Academic Press, London, pp 47-64.

Junk WJ, Piedade MTF, Wittmann F, Schöngart J, ParolinP (2010) Amazonian Floodplain Forests: Ecophysiology, biodiversity and sustainable management. Springer, Ecological Studies, Vol. 210. pp 62-101

Junk WJ, Piedade MTF, Schöngart J, Cohnhaft M, Adeney JM, Wittmann F (2011) A classification of major naturally occurring Amazonian lowland wetlands. Wetlands 31:623640.

Körner C (2006) Forests, biodiversity and $\mathrm{CO}_{2}$ : surprises are certain. Biologist 53: 82-90 Korning J, Balslev H (1994) Growth and mortality of trees in Amazonian tropical rain forest in Ecuador. J. Veg Sci 4: 77-86. 
Kubitzki K (1989) The ecogeographical differentiation of Amazonian inundation forests. Plant Syst Evol 162: 285-304.

Kurzatkowski D, Leuschner C, Homeier J (2015) Effects of flooding on trees in the semideciduous transition forests of the Araguaia floodplain, Brazil. Acta Oecol 69: 21-30.

Laurance WF, Oliveira AA, Laurance SG, Condit R, Nascimento HEM, Sanchez-Thorin AC, Lovejoy, TE, Andrade A, D’Angelo S, Ribeiro JE, Dick C W (2004) Pervasive alteration of tree communities in undisturbed Amazonian forests. Nature 428: 171-175. Lewis SL, Brando P, Phillips OL, van der Heijden GMF, Nepstad D (2011) The 2010 Amazon drought. Science 331: 554.

Lewis SL (2006) Tropical forests and the changing earth system. P Roy Soc Lond B BioB 361: 195-210

Lewis SL, Lopez-Gonzalez G, Sonké B (2009) Increasing carbon storage in intact African tropical forests. Nature 477: 1003-1006.

Lucas CMJ, SchöngartJ, SheikhP, WittmannF, Piedade MT, McGrath DG(2014)Effects of land-use and hydroperiod on aboveground biomass storage and productivity in secondary Amazonian floodplain forests. Forest Ecol Manag 319:116-127.

Martins A, Kardec E (2006) Relações solo-geoambiente em áreas de ocorrências de Ipucas na planície do Médio Araguaia - Estado de Tocantins.Rev. Árvore 30(2): 297-310.

Melack JM, Hess LL (2010) Remote sensing of the distribution and extent of wetlands in the Amazon basin. In: Junk WJ, Piedade MTF, Wittmann F, Schöngart J, Parolin P (eds) Central Amazonian floodplain forests: ecophysiology, biodiversity and sustainable management, pp. 43-59. Springer, Berlin.

Nebel G, Kvist LP, Vanclay JK, ChristensenH, Freitas L,Ruíz J (2001)Structure and floristic composition of flood plain forests in the Peruvian Amazon. I. Overstorey. Forest Ecol Manag150:27-57. 
Nebel G, Kvist LP, Vanclay JK, Vidaurre H (2001) Forest dynamics in flood plain forests in the Peruvian Amazon: effects of disturbance and implications for management. Forest Ecol Manag150(1): 79-92.

Olivares I, Svenning JC, von Bodegan PM, Balsev H (2015) Effect of warming and drought on the vegetation and plant diversity in the Amazon basin. Bot Rev 81: 42-69.

Parolin P, Ferreira LV, Albernaz AL,Almeida SS(2004)Tree species distribution in varzea forests of Brazilian Amazonia. Folia Geobotanica39:371-383.

Phillips OL, Hall P, Gentry AH, Sawyer SA, Vasquez R (1994) Dynamics and species richness of tropical rain forests. P Natl Acad Sci USA 91: 2805-2809.

Phillips OL, Gentry AH (1994) Increasing turn-over through time in tropical forests. Science 263: 954-958.

Phillips JG, Cane MA, Rosenzweig C (1998) ENSO, seasonal rainfall patterns and simulated maize yield variability in Zimbabwe. Agr. Forest Meteorol., 90: 39-50.

Phillips OL, Aragao LE, Lewis SL, Fisher JB, Lloyd J, Lopez-Gonzalez G, Malhi, Y, Monteagudo A, Peacock J, Quesada C A, van der Heijden G, Almeida S, Amaral I, Arroyo L, Aymard G (2009) Drought sensitivity of the Amazon rainforest. Science 323:1344-1347.

Rankin-de-Merona JMRW, Hutchings H, Lovejoy TE (1990) Tree mortality and recruitment over a five-year period in undisturbed upland rainforest of the central Amazon. Chapter 29: pgs. 573-584, In: Gentry AH (ed) Four Neotropical Forests. New Haven: Yale University Press.

Rosales J, Petts G, Salo J (1999) Riparian flooded forests of the Orinoco and Amazon basins: A comparative review. Biodiversity Conservation 8: 551-586.

Schöngart J, Wittmann F, Piedade MTF, Junk WJ, Worbes M (2005) Wood growth patterns of Macrolobium acaciifolium (Benth.) Benth. (Fabaceae) in Amazonian black-water and white-water floodplain forests. Oecologia 145:454-461. 
Schöngart J, Wittmann F, Worbes M (2010) Biomass and net primary production of Central Amazonian floodplains forests. In: Junk WJ, Piedade MTF, Wittmann F et al. (eds) Amazonian floodplain forests: ecophysiology, biodiversity and sustainable management. Springer New York, pp 347-388.

Schöngart J, Arieira J, Felfili Fortes C, Cezarine de Arruda E, Nunes da Cunha C (2011) Age-related and stand-wise estimates of carbon stocks and sequestration in the aboveground coarse wood biomass of wetland forests in the northern Pantanal, Brazil. Biogeosciences 8:3407-3421.

Sombroek W (2001) Spatial and temporal patterns of Amazon rainfall. Ambio 30: 388-396. Terborgh J, Andresen E(1998)The composition of Amazonian forests: patterns at local and regional scales. J Trop Ecol14:645-664.

Van Nieuwstadt MGL, Sheil D (2005)Drought, fire and tree survival in a Borneo rain forest, East Kalimantan, Indonesia. J Ecol93: 191-201.

Ward JV, Wiens JA (2001)Ecotones of riverine ecosystems: role and typology, spatiotemporal dynamics, and river regulation. Ecohydrology and Hydrobiology1:25-36.

Williamson GB, Laurance WF, Oliveira AA, Delamonica P, Gascon C, Lovejoy TE,Pohl L(2000)Amazonia tree mortality during the 1997 El Niño drought. Cons Biol14: 15381542.

Wittmann F, Zorzi BT, Tizianel FAT, Urquiza MVS, Faria RR, Sousa NM, et al. (2008) Tree species composition, structure and aboveground wood biomass of a riparian forest of the lower Miranda River, Southern Pantanal, Brazil. Folia Geobot 43:397-411.

Wittmann F, Junk WJ, Schöngart J (2010) Phytogeography, species diversity, community structure and dynamics of central Amazonian floodplain forests. In: Junk WJ, Piedade MTF, Parolin P, Wittmann F, Schöngart J (eds) Central Amazonian Floodplain forests: ecophysiology, biodiversity and sustainable management. Ecological Studies, Springer. 
Wittmann F, Householder E, Piedade MTF, Assis RL, Schöngart J, Parolin P, Junk WJ (2013). Habitat specificity, endemism and the neotropical distribution of Amazonian whitewater floodplain trees. Ecography36: 690-707.

Worbes M (1997) The forest ecosystem of the floodplains. In: Junk W (ed) The Central Amazon Floodplain: Ecology of a Pulsating System. Ecological Studies 126, Springer, Berlin.

Worbes M, Klinge H, Revilla JD, Martius C (1992) On the dynamics, floristic subdivision and geographical distribution of varzea forests in Central Amazonia. J Veg Sci 3: 553-564. Wright SJ (2005) Tropical forests in a changing environment. Trends Ecol Evol 20: 553560.

Zanne AE, Lopez-Gonzalez G, Coomes DA, Ilic J, Jansen S, Lewis SL, Miller RB, Swenson NG, Wiemann MC, Chave J (2009) Data from: Towards a worldwide wood economics spectrum. Dryad Digital Repository. doi:10.5061/dryad.234. 


\section{Chapter 4}

Variation of photosynthetic activity in the drought-affected floodplain forests of Araguaia River, Brazilian Amazon

Dariusz Kurzatkowski 


\section{Abstract}

The Araguaia floodplain area is located in the transition zone of Amazon forest and cerrado vegetation and is characterized by the occurrence of annual floods followed by pronounced dry and wet seasons. We measured net photosynthesisAinfour tree species during the three mainstages: aquatic phase, terrestrial dry phase and terrestrial wet phase. We studied the gas exchange of sun and shade leaves underambientconditions, using a meteorological tower to access the branches of trees. Gas exchange was measured using a portable Infra-Red Gas Analyzer, model LCi, ADC, Hoddesdon, UK. Environmental conditions(precipitation, flood level, ground water level, soil moisture, sun radiation and treephenology) were recorded. We observed the highest reduction in A during the aquatic phase, when the soil was saturated with water: sun leaves ofPiranhea trifoliatareduced A by about $22 \%$, shade leaves of Amoioua guianensis by about $60 \%$ as compared tothe terrestrial wet phase,during the terrestrial dry phase we observed lower decreases of A. During the terrestrial wet phase we measured the highest Ain shadeleaves ofall species and in sun leaves ofAmoioua guianensis.The observed midday decreases in photosynthetic activity were the effect of the stressed water status of the leaves. Ourphenological observationsindicateadaptation of Piranhea trifoliatato the aquatic phase byleafsenescenceat the beginning of this phase. Vochysia divergens manifested pronounced leaf fall during terrestrial dry phase. 


\subsection{Introduction}

The region of the Araguaia floodplain is characterized by high seasonal fluctuations. The transition between flooded, wet and dry conditions may cause stress and limit the vegetation's photosynthetic activity. Changes in photosynthesis directly affect the production of biomass (Long et al. 2006; von Caemmerer\& Evans 2010). Seasonal and inter-annual variability in vegetation productivity has profound impacts on the global carbon cycle (Poulter et al. 2014; Zhag et al. 2014; Keppel-Aleks et al. 2014; Gatti et al. 2014; Schimel et al. 2015; Cleveland et al. 2015). Understanding the mechanisms that link environmental variability and vegetation productivity is particularly important to supportmodelsof Earth system feedbacks to projections of possible future climate conditions (Keppel-Aleks et al. 2014; Boisier et al. 2015).

One of the major reasons for limitations of photosynthes in trees of the Araguaia floodplain forest, as typical for the Central Amazon (where most studies on the physiology of inundated trees were conducted), is water flooding. The long-term annual flooding, defined by Junk et al. (1989) as flood-pulse,causes phenological, morphological and physiological responses of tree species (Parolin 1997, Schlüter and Furch 1992, Waldhoff et al.1998, Worbes 1985, 1997). Most investigations in floodplain forests studied seedlingsunder controlled conditions (Meyer 1991; Waldhoff et al. 1998). Little is known about gas exchange in a canopy of mature trees, or about the responsesof species with different growth strategies (Parolin 1999; Parolin 2000; Piedade et al. 2000). During inundation, anaerobic conditions (Kozlowski 1984, Worbes 1986), cause a reduction of root activity (Meyer 1991), water deficit in the crown (Worbes 1997) and leaf shedding inmany species (Adis et al. 1979, Ayres 1993, Parolin 1997, Wittmann \& Parolin 1999) and induce cambial dormancy and the formation of annual rings in the wood (Worbes 1985, 1986). An indirect consequence of flooding is a decrease of oxygen concentration, which causes decreasein photosynthesis, respiration and the transport of photoassimilates (Taiz \&Zeiher, 1991). Anaerobicconditions also cause reductionsofstomatal conductance and, thus, rate of photosynthesis (Fernandez 2006, Fernandez et al. 1999, Lopez and Kursar 1999, Parolin 2001, Rengifo et al. 2005). Even in flood-tolerant trees, photosynthetic rate decreases under flood because of decreased stomatal conductance. Several studies show that flooding does 
not completely impede physiological processes, as some evergreen tree species are photosynthetically active (Maia 1997, Parolin 1997), others even flush new leaves or produce flowers and fruits during the flood period (Ayres 1993, Worbes 1997, Ziburski 1991).

Photosynthesis oftropical tree species isreported to be co-limited by stomatal and nonstomatal factors (Mielke et al. 2003). One very important stomatal factor is leaf temperature, which can affect photosynthesis both directly and indirectly. Direct influence,via changes in the activity of enzymes and electron transport (Sage and Kubien 2007), involves changes in the activity of ribulose-1,5-carboxylase, oxygenase and processes associated with the regeneration of rubisco's substrate, ribulose-1,5-bisphosphate (RuBP) through the Calvin cycle.Indirect influences may be exerted through the leaf-to-air vapor pressure differenceand its influence on stomatal conductance.

An important indicatorof stress adaptation in plants is the water use efficiency (WUE). WUE gives the relation between rate of photosynthesis $A$ and rate of transpiration $E$ (Larcher 2003).Reduction of stomatal conductivity in water-limited conditions causes relatively higher decreases of transpiration as compared to photosynthesis, thus increasing effective Water-Use-Efficiency (Taiz and Zeiger, 1991). Quantification of WUE provides a metric to evaluate a plant's success in utilizing limited soil water resources (Nogueira et al., 2004). High WUE values are characteristic forplants adapted to environments with low wateravailability.

The Araguaia floodplain is located atthe southeastern boundary of the Amazon. The transition of vegetation from forest to cerrado occurs in this area. Driving factors of these changes in plant cover are longer dry seasons, lower annual precipitationandconsequently, lower soil watercontents. Investigationsof evapotranspiration rates in the Araguaia floodplain indicate a decrease in the dry season (average $3.7 \mathrm{~mm} \mathrm{day}^{-1}$ ) During the wet season, and particularly during the flood period,an increase of evapotranspiration rate was measured(average $4.1 \mathrm{~mm} \mathrm{day}^{-1}$;Borma at al. 2009). In contrast to these findings, evaporation rates increased duringthe dry seasonat sites in Manaus, Santarem and Rondonia, with an annual precipitation of more than 1900 mm (da Rocha et al. 2009). 
However, data onhow different species of forest treesrespond to seasonal changes in the Amazonian region are lacking. In this study, we provide information onphotosynthetic responses of four tree species fromdifferent successional groups to aquatic, terrestrial dry and terrestrial wet conditions. We investigate the physiological response of adult trees to seasonal changes in soil moisture content, radiation and leaf temperature, with regard to transpiration, stomatal conductance and water-use efficiency in natural conditions. 


\subsection{Materials and methods}

\subsubsection{Study site}

The study site islocated in the Araguaia floodplain forest, in Cantão State Park in the southeastern Amazon in Brazil. Cantão State Park covers 89,000 ha of tropical forest and is situated in the transition zone between two dominant Brazilian biomes: the Amazon forest in the west and the cerrado (Brazilian savanna) in the east. Southwest of the study area is Bananal Island, the largest river island in the world, seasonally flooded and covered with forest, cerrado and grassland vegetation (Fig 1).

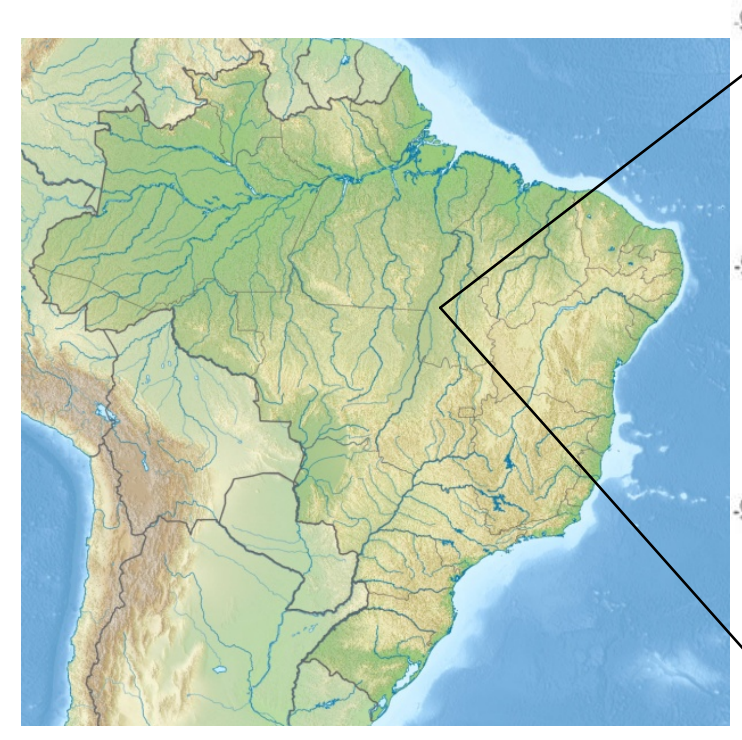

(A)

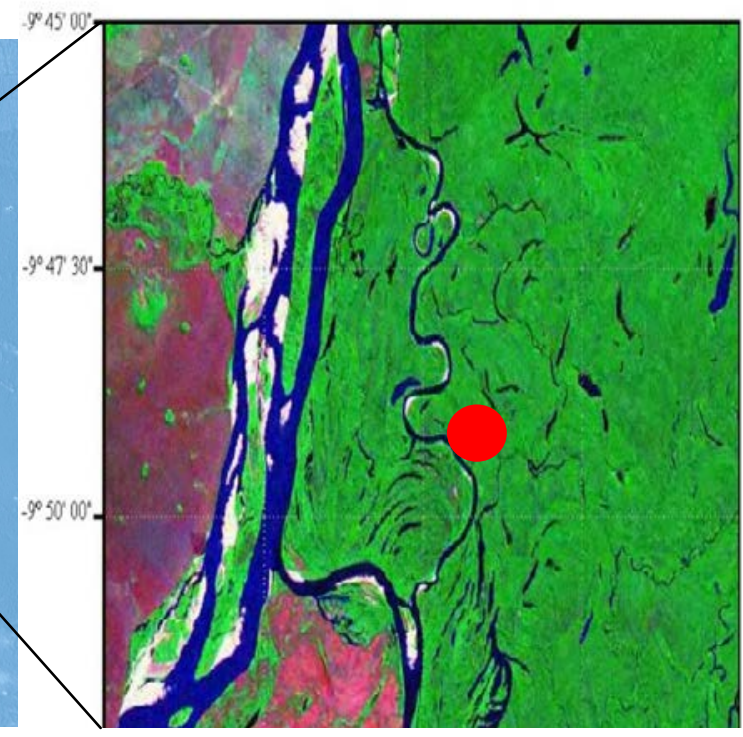

(B)

Figure 1: (A) Localization of the research area in Brazil, (B) in the Reserve of Cantão Park. (Source: http://www.ecologica.ws)

The experimental site with the geographic coordinates of $9^{\circ} 49^{\prime} 16^{\prime \prime} \mathrm{S}$ and $50^{\circ} 08^{\prime} 55^{\prime \prime} \mathrm{W}$ is called Javaezinho and lies about $260 \mathrm{~km}$ west of Palmas, the capital of the state of Tocantins. This site was established by LBA project (Large-scale Biosphere Atmosphere Experiment in Amazonia)in 2003, and isequipped with a $42 \mathrm{~m}$ tall micro-meteorological tower to measure the carbon-flux between forest and atmosphere.

The Araguaia floodplain region is characterized by pronounced seasonal changes. Bothinundation and dry periods occur annually with varying flood levels. In the study 
areas,maximum registered flood levels were $3.5 \mathrm{~m}$ during inundation periods of up to five months. The forest overstorey is $28 \mathrm{~m}$ high with the same emergent trees up to $32 \mathrm{~m}$, with closed upper canopy, open understorey and an above-ground biomass of $116.8 \mathrm{Mg} \mathrm{ha}{ }^{-1}$ (Kurzatkowski 2015).The soils of the study sites are quite variable, ranging from upland red-yellow and yellow Oxisols and red-yellow Ultisols to alluvial soils with hydromorphic lateritic and gleyic characteristics (DNPM, 1978). The soils on the floodplains are acidic and nutrient-poor Dystrophic Plinthosols and Gleysols (Martins and Kardec, 2006). The climate of the region is hot and semi-humid, with an average annual precipitation of $1552 \mathrm{~mm}$. The rainy period lasts from November to April, followed by a distinct dry season from June to August, usually without any precipitation. The average annual temperature is $26{ }^{\circ} \mathrm{C}$, the highest mean monthly temperature is $30{ }^{\circ} \mathrm{C}$ in August and September, while the lowest mean monthly temperature is $22{ }^{\circ} \mathrm{C}$ in July. Relative air humidity varies between $80 \%$ in the rainy and $60 \%$ in the dry season.A more detailed description of the study sites' climate characteristics(net radiation, relative humidity and water vapor pressure deficit)can be found inBorma at al. (2009).

\subsubsection{Species descriptions}

Four common forest trees species were included in the investigation. The trees represent dominant tree species, responsible for the bulk of carbon sequestration, and presenta different range of growth strategies, successional status, leaf morphology and phenology. The four tree species were as follows:

-Piranhea trifoliata Baill., Family Euphorbiaceae, commonly named Piraeira. It is a semi-deciduous, non-pioneer, heliophytic but shade tolerant species. The leaves are small, 8$12 \mathrm{~cm}$ long and 3-5 cm wide. The species is commonly found in the flooded forest. The wood is heavy, with a density of $0.95-1.00 \mathrm{~g} / \mathrm{cm}^{3}$. The investigated tree was $27.0 \mathrm{~m}$ high with a DBH (diameter at breast height) of $62.0 \mathrm{~cm}$.

-Amoioua guianensis Aubl, Family Rubiaceae, is commonly named Marmelada brava. An evergreen species, sciophyte to heliophyte, characteristic of cerradões and pluvial 
forests. It has simple, opposite leaves, 9-12 cm long and 3-9 cm wide. The wood density is $0.67 \mathrm{~g} / \mathrm{cm}^{3}$. The plant has a slow rate of growth, even when young. The investigated tree was $19.8 \mathrm{~m}$ high and had a DBH of $36.5 \mathrm{~cm}$.

- Vochysia divergens Pohl, Family Vochysiaceae, commonly named Cinzeiro. Evergreen, a pioneer species, heliophyte, selective hygrophyte, and usually growing in the forest of the Pantanal and of the Araguaia River where it is abundant. It has simple leaves, 7$13 \mathrm{~cm}$ long and $2.5-4.3 \mathrm{~cm}$ wide, on petiole $2-3 \mathrm{~cm}$ long. The wood is moderately heavy, with a density $0.66 \mathrm{~g} / \mathrm{cm}^{3}$. The investigated tree was $15.4 \mathrm{~m}$ high and had a DBH of $16,5 \mathrm{~cm}$.

-Nectandra rigida (Kunth) Nees, Family Lauraceae, commonly named Amescla preta or Canela amarela. An evergreen tree, heliophyte growing under diffuse light in gallery forests with humid soils. It has simple leaves $10-14 \mathrm{~cm}$ long and 5-10 $\mathrm{cm}$ wide. The wood has a density of $0.54 \mathrm{~g} / \mathrm{cm}^{3}$. The tree was $12.90 \mathrm{~m}$ high and had a DBH of $14.2 \mathrm{~cm}$.

\subsubsection{Gas-exchange measurements}

The leaf gas-exchange was measured with a portable IRGA (Infra-Red Gas Analyzer), model LCi, ADC, BioScientific Ltd, Hoddesdon, UK. It is a slimmed-down photosynthesis system, which measures leaf $\mathrm{CO}_{2}-$ and $\mathrm{H}_{2} \mathrm{O}$ gas exchange via the gases' absorption of infrared light.Based on differences in $\mathrm{CO}_{2-}$ and $\mathrm{H}_{2} \mathrm{O}$-concentration between a reference chamber and the chamber containing the leaf (delta $\mathrm{CO}_{2}$ and delta $\mathrm{H}_{2} \mathrm{O}$ ), the $\mathrm{LCi}$ calculatesnet photosynthetic rate Aand other parameters per unit area of the inserted leaf. Measurements were taken under ambient conditions, artificial manipulation of light intensity, relative humidity, temperature and $\mathrm{CO}_{2}$-concentration are not possible. Recorded parameters were:stomatal conductance for $\mathrm{H}_{2} \mathrm{O}$ (gs), transpiration rate (E), sub-stomatal $\mathrm{CO}_{2-}$ concentration (Ct), reference concentration of $\mathrm{CO}_{2}$, delta $\mathrm{CO}_{2}$ and rate of net photosynthesis A. Leaf temperature $\left({ }^{\circ} \mathrm{C}\right)$ and photosynthetically active radiation (PAR) wererecordedwith sensors installed on a chamber of the IRGA. The flow rate in all measurements was set to $250 \mathrm{ml} \mathrm{min}^{-1}$, the leaf area clamped into the chamberis6.25 $\mathrm{cm}^{2}$. Prior to the measurements, the LCi was warmed-up for about 5 minutes. After placing the 
leaf into the leaf-chamber it was allowed to acclimatize to the conditions in the chamber. Measurements were conductedduring one day during the three mainseasons in 2004:

1) Aquatic phase: in April,

2) Terrestrial dry phase: in July,

3) Terrestrial wet phase: in October.

The tree canopy was accessed using the meteorological tower. For each studied species, five fully-expanded, mature leaves were chosen in each of two different positions: a) exposed to the sun (uperstory leaves), b) and in the shade (sub-canopy). Due to closed vegetation and relatively small accessible trees, measurements on Nectandra rigidaand Vochysia divergens could be conducted on shade leaves only.OfAmoioua guianensis and Piranhea trifoliataboth sun and shade leaves were investigated. To investigate of the seasonal changes of $A$, only light saturated measurements were included. Using information from scientific literature, we definedlight saturation to be reachedat $200 \mu \mathrm{mol} \mathrm{m} \cdot \mathrm{m}^{-2} \cdot \mathrm{s}^{-1}$ forshade leaves and at $800 \mu \mathrm{mol} \mathrm{m}$ ${ }^{2} \cdot \mathrm{s}^{-1}$ forthe sun leaves (Ramos and Grace 1990; Tompson et al. 1992; Kitajima 1994, Lüttge, 2008). Measurements were recorded 3 times a day, inthe morning at $8 \mathrm{am}$, midday at 12.00 and in the afternoon at $3 \mathrm{pm}$. Measurementsstarted in the highest tree, going down successively on the tower, to the lower canopy trees and branches. For each series of measurements the same leaves were used. If a measured leaf happened to be destroyed during the term, it was replaced with a neighboring leaf.

\subsubsection{Meteorological measurements}

Data of precipitation and photosynthetically active radiation (PAR) were collected with a meteorological station placed at the top of the $42 \mathrm{~m}$ tall micrometeorological tower. PAR was measured with an NR-LITE Net Radiometer. Soil moisture was measured using a frequency domain reflectometer placed in the soil, at a distance of $3 \mathrm{~m}$ fromthe tower, and located horizontally in a shaft wall at depths of 0.1, 0.5, 1.0 and $2.0 \mathrm{~m}$. Volumetric soil moisture was estimated using a polynomial calibration of sandy soil. The flood level was manually recorded by observations of hydrometric rulers every 4 weeks. Groundwater level 
was measured every 4 weeks using asimple piezometer, $5 \mathrm{~m}$ in depth, made from a plastic tube andlocated $5 \mathrm{~m}$ east of the tower.

\subsubsection{Water-use efficiency}

Water Use Efficiency (WUE) was calculated as ratio of net photosynthetic rate A and Transpiration rate E(Giorio et al. 1999; Prado et al. 2004):

Leaf $\mathrm{WUE}=$ Photosynthetic rate $\mathrm{A} /$ Transpiration rate $\mathrm{E}$

\subsubsection{Phenology}

Phenological data of the trees, such as the production of new leaves, senescence of leaves and the appearance of flowers or fruits, was monitored every 4 weeks over a period of one year. The trees were growing in natural environmental conditions and exhibited cyclical changes.

\subsubsection{Statistical analyses}

Tests for normal distribution of the dataand comparison of means of parameters were done with T-test, using the program Statistica 12. 


\subsection{Results}

\subsubsection{Climate and environmental condition}

\subsubsection{Seasonal patterns of precipitation, flooding and ground water level}

Atotal precipitation of $1682 \mathrm{~mm}$ with average distribution was recorded in 2004 (mean precipitation 2004-2008 was $1630 \mathrm{~mm}$ ). Rainfall started at the end of September and endedin May, with the highest amountof precipitation in March (384 mm). The months June and July were without any precipitation (Fig. 2 A).

The year 2004 was characterized by a relatively high level of inundation as compared to other years. The highest level was reached in April $(355 \mathrm{~cm})$,the soil surface was covered with water for a period of 4 months. At the end of May, after the the aquatic phase, the groundwater level started to decrease and continued to decline until October, when the maximum depth of $435 \mathrm{~cm}$ was reached. The round water level stayed this low throughout November and December.

\subsubsection{Soil moisture}

The occurrence of strong precipitation in early2004 increased soil moisture inall soil depths (Fig. 2 D). FromFebruary on, the soil surface was inundated with fluvial water (Fig. 2 C)originating from the river. Thus, soil conditions changed from aerobic during a terrestrial phase to anaerobic in the aquatic phase. In consequence, we observed constantly saturated soil moisture levels in all depths up to 200 cmfrom February to June. During the period of inundation, and continuing until June 2004 the surface soil layer at $0.1 \mathrm{~m}$ showedmarkedly higher soil moisture contentsthan deeper layers. We assumed that thiswas caused by the higher content of organic material in the soil surface. 

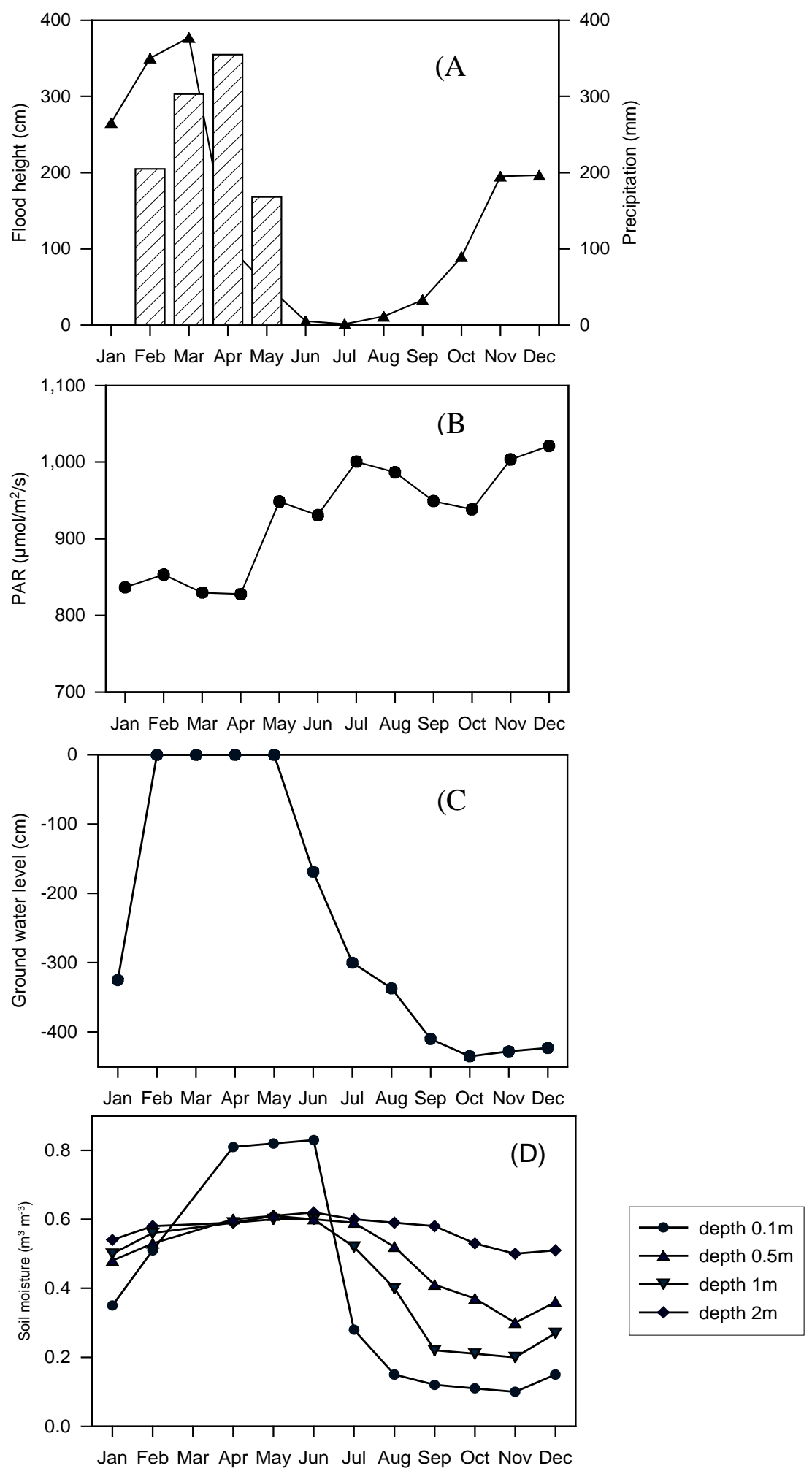

Figure 2: Monthly means of environmental variables observed at the experimental site during the year 2004: A Precipitation (solid line) and flood height (bars); (B) Photosynthetically active radiation; (C) Ground water level; (D) Soil moisture. 
One month after the end of inundation, the soil moisture continued to be high, and only in July did itbegin to decrease. The decline of moisture in the surface soilwas faster than in the deeper layers.

The upper soil profile of $10 \mathrm{~cm}$ depth showed the most evident seasonal variation, fluctuating between $0.1 \mathrm{~m}^{3} \cdot \mathrm{m}^{-3}$ during the terrestrial phase and $0.84 \mathrm{~m}^{3} \cdot \mathrm{m}^{-3}$ during the aquatic phase. Indepths of $50 \mathrm{~cm}$ and $100 \mathrm{~cm}$, differences were less pronounced, ranging from $0.2 \mathrm{~m}^{3} \cdot \mathrm{m}^{-3}$ during the terrestrial phase to $0.6 \mathrm{~m}^{3} \cdot \mathrm{m}^{-3}$ during the aquatic phase. At a depth of $200 \mathrm{~cm}$,the smallestdifference in water contents during aquatic and terrestrial phase was observed, they only varied from 0.5 to $0.6 \mathrm{~m}^{3} \mathrm{~m}^{-3}$.

The onsetof precipitation in September did not directly increase soil moisture, since interception by vegetation and organic material on top of the soil was high. Therefore,soil moisture continued to decrease for two months into the rainy season. A minimum value of soil moisture was reached in November. In December 2004 soil moisture in all layers began to increase.

\subsubsection{Changes in photosynthetic active radiation}

The lowest monthly average ofPhotosynthetically Active Radiation (PAR) we measuredwas

$836 \mu \mathrm{mol} \mathrm{m} \mathrm{m}^{-2} \cdot \mathrm{s}^{-1}$, whichwas recorded during the rainy season in the period from January to April (Fig. 2 B). During this time, extended durations of cloud cover and flooding occurred simultaneously. PAR started to increase at the end of the rainy season in May 2004. The highest mean of PAR values, which peaked at $1000 \mu \mathrm{mol} \cdot \mathrm{m}^{-2} \cdot \mathrm{s}^{-1}$ wereregistered during the terrestrial dry periodin July 2004. With the beginning of the rainy season in October, PAR decreased to an average $934 \mu \mathrm{mol} \mathrm{m} \mathrm{m}^{-2} \cdot \mathrm{s}^{-1}$. In November and December 2004, PAR measured atthe study site was surprisingly increased to $1016 \mu \mathrm{mol} \mathrm{m} \mathrm{m}^{-2} \cdot \mathrm{s}^{-1}$. 


\subsubsection{Tree phenology}

Piranhea trifoliata Baill is a deciduous species which sheds leaves atthe beginning of the aquatic phase and remains bare for 7 weeks during this phase (Fig. 3). The leaves had fallen by the time of the highest flood at the end of March and April. The new leaf flush startedbefore the end of the aquatic phase in April. Leaf fall and leaf flush are distinctly separated. Floweringbegins directly after the end of the aquatic phase and extends into the three months of terrestrial dry phase. The new leaves emergingat the end of the aquatic phase seemed healthy and in good condition. During the dry periods, leaves at the top of the canopy started to wilt.This was observed during midday hours in July. During the terrestrial wet phase no wilting was observed.

Amaioua guianensis Aubl., is anevergreen species.Ripening fruitwas observed during the aquatic phase, pronounced senescence of leaves during the terrestrial dry phase and flowering during the terrestrial wet phase(Fig. 3).

Vochysia divergens Pohlis an evergreen pioneer species. This tree blooms at the end of the terrestrial dry phase and the fruits ripen before and at the beginning of aquatic phase(Fig. 3). Leaf fall was pronounced at the end of the dry phase.

Nectandra rigida(Kunth) Neesis also an evergreen species. Flowering was observed during the aquatic and terrestrial wet phase,fruit ripening in the dry phase(Fig. 3). In contrast to all other species, Nectandra rigidauniformly shed leaves throughout the entire year. The flush of the new leaves was also constant 


Aquatic phase
Jan Feb Mar Apr May Jun Jul Aug Sept Oct Nov Dec
Piranhea trifoliata
\begin{tabular}{|l|l|l|l|l|l|l|l|l|l|l|l|l|}
\hline Ieafflush & & & & & & & & & & & & \\
\hline leaf senescence & & & & & & & & & & & & \\
\hline leaffall & & & & & & & & & & & & \\
\hline flowering & & & & & & & & & & & & \\
\hline fruits ripen & & & & & & & & & & & & \\
\hline
\end{tabular}

\section{Amoioua} guianensis

\begin{tabular}{|l|l|l|l|l|l|l|l|l|l|l|l|l|}
\hline Ieaf flush & & & & & & & & & & & & \\
\hline Ieaf senescence & & & & & & & & & & & & \\
\hline Ieaf fall & & & & & & & & & & & & \\
\hline flowering & & & & & & & & & & & & \\
\hline fruits ripen & & & & & & & & & & & & \\
\hline
\end{tabular}

Vochysia

divergens

\begin{tabular}{|l|l|l|l|l|l|l|l|l|l|l|l|l|}
\hline Ieaf flush & & & & & & & & & & & & \\
\hline Ieaf senescence & & & & & & & & & & & & \\
\hline Ieaf fall & & & & & & & & & & & & \\
\hline flowering & & & & & & & & & & & & \\
\hline fruits ripen & & & & & & & & & & & & \\
\hline
\end{tabular}

Nectandra rigida
\begin{tabular}{|l|l|l|l|l|l|l|l|l|l|l|l|l|}
\hline leaf flush & & & & & & & & & & & & \\
\hline leaf senescence & & & & & & & & & & & & \\
\hline leaf fall & & & & & & & & & & & & \\
\hline flowering & & & & & & & & & & & & \\
\hline fruits ripen & & & & & & & & & & & & \\
\hline
\end{tabular}

Figure 3: Phenology of four study species during the year 2004. Darkened squares show activity of action. Darker squares show higher intensity. 


\subsubsection{Inter- seasonal variability in gas exchange}

The net photosynthetic rate of sun leaves of evergreen speciesAmoioua guianensis was9.95 $\mu \mathrm{mol} \mathrm{m} \mathrm{m}^{-2} \cdot \mathrm{s}^{-1}$ during the aquatic phase which reduced to $8.70 \mu \mathrm{mol} \mathrm{m} \mathrm{m}^{-2} \cdot \mathrm{s}^{-1} \mathrm{during}$ the terrestrial dry phase and increased to $10.44 \mu \mathrm{mol} \cdot \mathrm{m}^{-2} \cdot \mathrm{s}^{-1}$ during the terrestrial wet phase (Fig. 4 A).

The species Piranhea trifoliataexibitedthe lowest level of A of $8.77 \mu \mathrm{mol} \mathrm{m} \mathrm{s}^{-1}$ during the aquatic phase (Fig. $4 \mathrm{~B}$ ). During the terrestrial dry and terrestrial wet phases, A was higher and reached values of 11.74 and $11.27 \mu \mathrm{mol} \cdot \mathrm{m}^{-2} \mathrm{~s}^{-1}$, respectively.

Thenet photosynthetic rates of shade leaves of Piranhea trifoliata andAmoioua guianensis were markedly lower than those of sun leaves. Thisdifference was observed during all seasons, but at about $50 \%$ most pronounced during the aquatic phase.

Shade leaves ofthe species Piranhea trifoliata, Amoioua guianensis and Vochysia divergens showed the same tendency for changes in mean of A, with lowest values during the aquatic phase and increases during the terrestrial dry and wet phases (Fig. $4 \mathrm{C}, \mathrm{D}, \mathrm{F}$ ). The highest reduction ofAfrom terrestrial dry to aquatic phase, by about $60 \%$, was observed in the evergreen species Amoioua guianensis,and the lowest (34\%)in thepioneer species Vochysia divergens. The species Nectandra rigidashowedthe lowest mean A during the dry phase

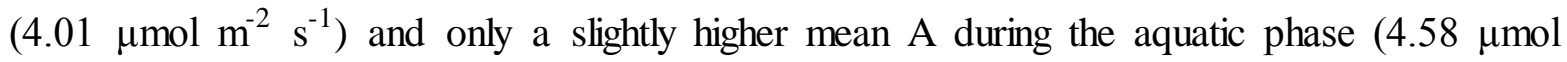
$\left.\mathrm{m}^{-2} \mathrm{~s}^{-1}\right)$ and terrestrial wet phase $\left(6.61 \mu \mathrm{mol} \mathrm{m} \mathrm{m}^{-2} \mathrm{~s}^{-1}\right)$. 

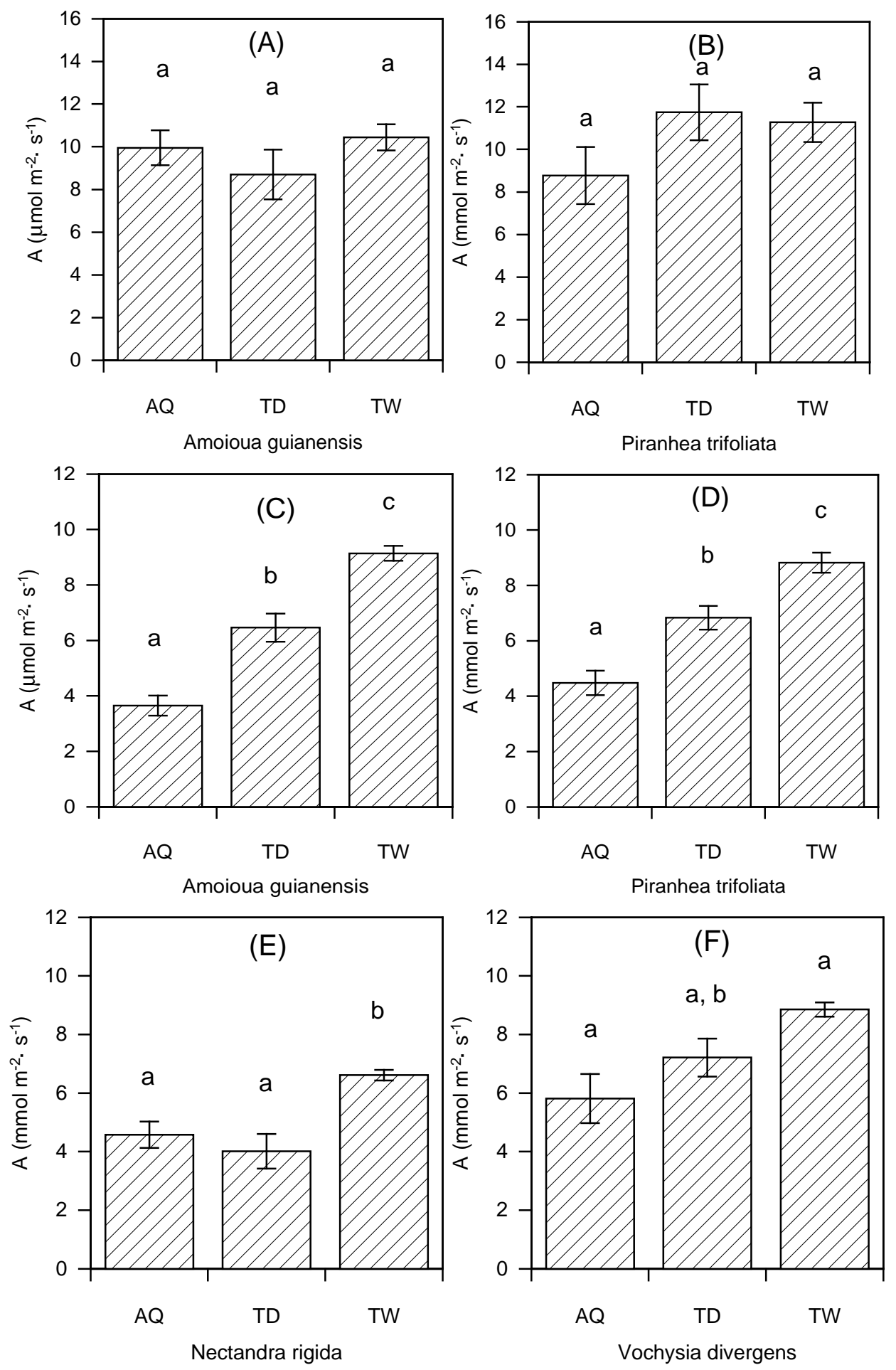

Figure 4: Mean \pm SE of light-saturated net photosynthesis $A$ in sun leaves (Fig. A, B) and shade leaves (Fig. C,D, E,F) during the Aquatic phase (AG), Terrestrial dry phase (TD) and the Terrestrial wet phase (TW). 


\subsubsection{Diumal patterns of photosynthetic activity}

Midday depressionof photosynthetic activity was observed in all species in bothsun and shade leaves during the terrestrial wet season.During aquatic and terrestrial dry seasons this tendency was not so clear and showedlarge variability between species and seasons(Tab 2). The highest midday depression (32\%) was measured onsun leaves in Piranhea trifoliata

\subsection{Discussion}

\subsubsection{Phenology of examined species}

Recording of phenological data confirmed that the examined tree species manifestedphenological adaptation to adverse conditions. In the deciduous species Piranhea trifoliata we observed responsestypical for flood- adapted trees in the form of leaves senescence during the aquatic phase. This species sheds the leaves at the beginning of the flooding and remainesfor the period of maximum inundation (Fig. 3). The new leaf flush occurres before the end of the aquatic phase. This observation confirmsstudies from central Amazonian flooded areas reported by Parolin (1997) or Schöngart et al. (2002).Piedade et al. (2000) also reported that many flood- adapted species in Amazonian floodplains areshedding their leaves during inundation. New leaves photosynthesize more efficiently than old leaves, and an observation of seasonal flushing of new leaves has therefore been hypothesized to promote greater photosynthetic capacity (Huete et al. 2006; Brando et al. 2010; Restrepo-Coupe et al. 2013).

We observed ripening and fall of fruits in Amoioua guianensis during the aquatic phase. The main means of dispersal in Amazonian floodplain trees are hydro- and ichthyochory (Gottsberger, 1978; Goulding, 1980; Moegenburg, 2002; Mannheimer et al. 2003), which can explain the close correlation between flooding and fruit maturation (Ziburski, 1991; Parolin et al. 2002). The most homogeneous phenological trait among different speciesoffloodplain trees is the period of fruit maturation during high water or at the end of the flooded period, as documented by Ziburski (1991) for 33 tree species from várzea and igapó. 
The observed leaf phenology for the evergreen trees species showed a tendency typical for dry areas, withthe highest litter fall occurring during thedry period. This was observed inAmaioua guianensis and also in thepioneer species Vochysia divergens (Fig. 3).

\subsubsection{Photosynthetic activity during aquatic phase}

The highest reduction was measured inPiranhea trifoliatawith reductions of 22\% insun and $49 \%$ inshade leaves as compared to the terrestrial wet phase (Tab 1). Two main factors maybe responsible for the reduction of Amax: a)photosynthetic capacity itself maybe affected, or b) stomatal limitationcan cause changes in $\mathrm{CO}_{2}$-assimilation (Junk et. al 2010).

We did not identify reductions of stomatal conductance and intercellular $\mathrm{CO}_{2}$ concentrationsin any of the four species during the aquatic period (Tab 1). 
Table 1: Seasonal gas exchange properties in sun and shade leaves of Amoioua guianensis, Piranhea trifoliata, Nectandra rigida and Vochysia divergens during the Aquatic phase (AQ), Terrestrial dry phase (TD) and Terrestrial wet phase (TW) in the Araguaia floodplain forest. Different letter behind the means indicate statistical difference between photosynthetic properties $(\mathrm{p}<0.05)$.

\begin{tabular}{|c|c|c|c|c|c|c|}
\hline & $\begin{array}{c}\text { Leaf temp. } \\
\left({ }^{\circ} \mathrm{C}\right)\end{array}$ & $\begin{array}{c}\text { Sub-stomatal } \\
\mathrm{CO}_{2} \\
(\mathrm{ppmv}) \\
\end{array}$ & $\begin{array}{l}\text { Transp. rate } \\
\left(\mathrm{mmol} \mathrm{m}^{-2} \mathrm{~s}^{-1}\right)\end{array}$ & $\begin{array}{c}\text { Stomatal } \\
\text { conductance of } \\
\mathrm{CO}_{2} \\
\left(\mathrm{mmol} \mathrm{m}^{-2} \mathrm{~s}^{-1}\right) \\
\end{array}$ & $\begin{array}{l}\text { Photo- } \\
\text { synthetic } \\
\text { rate } \\
\left(\mu \mathrm{mol} \mathrm{m}^{-2} \mathrm{~s}^{-1}\right) \\
\end{array}$ & $\begin{array}{l}\text { Water use } \\
\text { efficiency }\end{array}$ \\
\hline \multicolumn{7}{|c|}{ A. guianensis (sun) } \\
\hline $\mathrm{AQ}$ & $34.9 \pm 0.5 \mathrm{a}$ & $209 \pm 10 a$ & $3.4 \pm 0.3 \mathrm{a}$ & $163 \pm 19 a$ & $9.9 \pm 0.8 \mathrm{a}$ & 0.0029 \\
\hline TD & $36.8 \pm 0.5 \mathrm{a}$ & $185 \pm 10 a$ & $3.3 \pm 0.3 \mathrm{a}$ & $102 \pm 14 b$ & $8.7 \pm 1.1 \mathrm{a}$ & 0.0026 \\
\hline TW & $37.4 \pm 0.9 \mathrm{a}$ & $203 \pm 14 a$ & $5.2 \pm 0.3 b$ & $166 \pm 16 a$ & $10.4 \pm 0.6 \mathrm{a}$ & 0.0020 \\
\hline \multicolumn{7}{|c|}{ P. trifoliata (sun) } \\
\hline $\mathrm{AQ}$ & $35.7 \pm 0.5 \mathrm{a}$ & $222 \pm 13 a$ & $3.7 \pm 0.4 \mathrm{a}$ & $156 \pm 21 \mathrm{a}$ & $8.7 \pm 1.3 \mathrm{a}$ & 0.0024 \\
\hline TD & $37.9 \pm 0.3 b$ & $198 \pm 9$ a & $5.6 \pm 0.6 \mathrm{~b}$ & $183 \pm 27 a$ & $11.7 \pm 1.3 \mathrm{a}$ & 0.0021 \\
\hline TW & $37.6 \pm 0.4 \mathrm{~b}$ & $185 \pm 10 \mathrm{a}$ & $4.9 \pm 0.4 \mathrm{ab}$ & $153 \pm 21 \mathrm{a}$ & $11.2 \pm 0.9 \mathrm{a}$ & 0.0023 \\
\hline \multicolumn{7}{|c|}{$\begin{array}{l}\text { A. guianensis } \\
\text { (shade) }\end{array}$} \\
\hline $\mathrm{AQ}$ & $34.2 \pm 0.5 \mathrm{a}$ & $277 \pm 17 a$ & $3.2 \pm 0.3 \mathrm{a}$ & $137 \pm 15 a$ & $3.6 \pm 0.4 \mathrm{a}$ & 0.0011 \\
\hline TD & $36.6 \pm 0.3 b$ & $201 \pm 14 b$ & $3.2 \pm 0.3 \mathrm{a}$ & $90 \pm 10 \mathrm{~b}$ & $6.4 \pm 0.6 \mathrm{~b}$ & 0.0020 \\
\hline TW & $27.3 \pm 0.1 \mathrm{c}$ & $230 \pm 3 b$ & $1.5 \pm 0.1 \mathrm{~b}$ & $139 \pm 12 \mathrm{a}$ & $9.1 \pm 0.2 \mathrm{c}$ & 0.0061 \\
\hline \multicolumn{7}{|c|}{ N. rigida (shade) } \\
\hline $\mathrm{AQ}$ & $34.1 \pm 0.3 \mathrm{a}$ & $248 \pm 26 \mathrm{a}$ & $3.0 \pm 0.3 \mathrm{a}$ & $137 \pm 23 \mathrm{a}$ & $4.5 \pm 0.4 \mathrm{a}$ & 0.0015 \\
\hline TD & $36.5 \pm 0.3 b$ & $275 \pm 11 \mathrm{a}$ & $3.9 \pm 0.2 \mathrm{~b}$ & $116 \pm 18 a$ & $4.0 \pm 0.6 \mathrm{a}$ & 0.0010 \\
\hline TW & $31.8 \pm 0.1 \mathrm{c}$ & $246 \pm 6 a$ & $2.4 \pm 0.1 \mathrm{a}$ & $121 \pm 16 \mathrm{a}$ & $6.6 \pm 0.2 \mathrm{~b}$ & 0.0028 \\
\hline \multicolumn{7}{|c|}{ P. trifoliata (shade) } \\
\hline $\mathrm{AQ}$ & $36.0 \pm 0.6 \mathrm{a}$ & $247 \pm 19 a$ & $2.6 \pm 0.3 \mathrm{a}$ & $98 \pm 13 a$ & $4.4 \pm 0.4 \mathrm{a}$ & 0.0017 \\
\hline TD & $36.9 \pm 0.3 \mathrm{a}$ & $206 \pm 11$ a & $3.6 \pm 0.3 b$ & $99 \pm 13$ a & $6.8 \pm 0.4 \mathrm{~b}$ & 0.0019 \\
\hline TW & $30.1 \pm 0.1 b$ & $233 \pm 4 a$ & $2.2 \pm 0.1 \mathrm{a}$ & $146 \pm 11 b$ & $8.8 \pm 0.4 \mathrm{c}$ & 0.0040 \\
\hline \multicolumn{7}{|c|}{ V. divergens (shade) } \\
\hline AQ & $34.8 \pm 0.5 \mathrm{a}$ & $269 \pm 10 \mathrm{a}$ & $3.5 \pm 0.3 \mathrm{a}$ & $144 \pm 23 a$ & $5.8 \pm 0.8 \mathrm{a}$ & 0.0017 \\
\hline TD & $36.5 \pm 0.1 \mathrm{~b}$ & $246 \pm 11 a b$ & $4.7 \pm 0.1 \mathrm{~b}$ & $148 \pm 14 a$ & $7.2 \pm 0.6 \mathrm{ab}$ & 0.0015 \\
\hline TW & $32.2 \pm 0.1 \mathrm{c}$ & $231 \pm 4 b$ & $3.1 \pm 0.1 \mathrm{a}$ & $156 \pm 12 \mathrm{a}$ & $8.8 \pm 0.2 \mathrm{~b}$ & 0.0028 \\
\hline
\end{tabular}


This proves that A was not restricted from stomatal limitation during the aquatic phase. We assumed that the most important factor that caused the A reduction during the aquatic phase was soil saturation with water, which affected the soil physiochemical condition and, with this, the physiology and chemical conditions of the roots of the trees. The continuous monitoring of volumetric soil moisture up to $200 \mathrm{~cm}$ confirmed saturation of the soil layers for 5 month duringand after the aquatic phase (from February to July). At the time of the measurements during the aquatic phase, the trees had been inundated for over 3 months.

Another important factor that affected Aduring the aquatic phase was the lower photosynthetic active radiation (PAR). Due to the increased cloud cover, monthly averages of PAR during the aquatic phase (from January to April) were markedly lower $(\approx 820 \mu \mathrm{mol}$ $\left.\mathrm{m}^{-2} \cdot \mathrm{s}^{-1}\right)$ than during the terrestrial phase $\left(\approx 970 \mu \mathrm{mol} \mathrm{m} \mathrm{m}^{-2} \cdot \mathrm{s}^{-1}\right)$. This pattern was attributed to the effect of cloudiness during the aquatic phase and reduction in total solar radiation. This was observed also by study in East Brazilian Amazon (da Rocha et al. 2009).

High reduction oftranspiration rate insun- exposed leaves was observed in Piranhea trifoliata. Parolin (2000) observed reductions in transpiration in the flooded period for many floodplain tree species due to inhibition of aerobic root respiration during the flood season.

\subsubsection{Photosynthetic activity during a terrestrial dry phase}

The highest reduction ofnet photosynthetic rateA during the terrestrial dry phase was noted inAmoioua guianensisinsun- exposed leaves and inPiranhea trifoliata and Nectandra rigidain shadeleaves. Low values of stomatal conductance and intercellular $\mathrm{CO}_{2}$ concentration in Amoioua guianensis and Piranhea trifoliata led us to conclude that inthesespecies A was restricted by stomatal limitationduring the terrestrial dry phase(Tab 1). Schlüter, 1989; Parolin, 2000; Armbrüster etal. 2004 all reported stomatal limitation of photosynthesis in Amazonian floodplain trees due to water shortage.

The high values of stomatal conductance and intercellular $\mathrm{CO}_{2}$ concentrationrecorded in Nectandra rigidaand Vochysia divergenssuggest that these species did not experience water stress during the dry period. Parolin (2000), Maia and Piedade (2002) reported that 
Eschweilera tenuifolia, Hevea spruceana, Nectandra amazonum and Pouteria glomerata maintain constant photosynthetic activity under mild drought conditions. The deep root systems of these speciesare able to supply water even in comparatively dry conditions. (Armbrüster et al. 2004). Tree species growing in the Araguaia floodplain forests are subjected to an annual dry period of 3 months without any precipitation. On ourstudy site, the groundwater levelsfell to a depth of $3 \mathrm{~m}$ in July. Soil moisture at a depth of $2 \mathrm{~m}$ was 0.5 $\mathrm{m}^{3}$ water/ $\mathrm{m}^{3}$ soil. Ourobservation of high stomatal conductance even in the dry season indicates that the roots of the examined trees can reach the groundwater and do not suffer water limitations. Amazon upland forest is able to extract water even from the deepest soil layers (Nepstad et al. 1994; Jipp et al. 1998). Chauvel et al. (1992) found abundant roots at depths of 3 to $6 \mathrm{~m}$. Nepstad (1989) concluded that mature forests in the Eastern Amazon reaches water at $6 \mathrm{~m}$ depth. Borma et al. (2009) recorded at the same study site, average Evapotranspiration rates of about $3.7 \mathrm{~mm}^{-1 a y}{ }^{-1}$ throughout the whole dry season of 2004. However, Evapotranspiration rates in the aquatic phase wereslightly higher and averaged to $4.1 \mathrm{~mm}$ day $^{-1}$.

Amazon floodplain deciduous trees showhigher maximum rates of net assimilation than evergreen species (Parolin et al. 2001). This is confirmed by our measurements onPiranhea trifoliata, which is the one deciduous species in our investigation. Higher A during the terrestrial dry and terrestrial wet seasons were observed in this species as compared to Amoioua guianensis.In the evergreen species Amaioua guianensis,phenologicaladaptive mechanisms tothe dry phase,likeincreased leaf senescence, were observed.

Stomatal conductance during thedry period was reduced by about $40 \%$ in the shadeleaves (Tab.1). Only the pioneer species Vochysia divergens did not reduce stomatal conductance,itremained at the same level during the aquatic and the terrestrial wet phases. In the sun- exposed leaves, the species Piranhea trifoliata shows a considerablyhigher value of stomatal conductance $\left(0.18 \mu \mathrm{mol} \quad \mathrm{CO}_{2} \cdot \mathrm{m}^{-2} \cdot \mathrm{s}^{-1}\right)$ as compared to Amoioua guianensis $\left(0.10 \mu \mathrm{mol} \mathrm{CO} \cdot \mathrm{C}^{-2} \mathrm{~s}^{-1}\right)$.

InAmoioua guianensis, the evergreen species, we observed loss of leaves during the terrestrial dry period as an apparent strategy to cope withwater limitation (Fig. 3). The loss 
of leaves significantly reduced stomatal conductance of the remaining leaves, resulting in greater WUE during the terrestrial wet season.

\subsubsection{Photosynthetic activity during a terrestrial wet phase}

In all analysed species we observed the highest photosynthetic activity during the terrestrial wet phase. This season seems to be provide the most vavourable conditions for the trees investigated in this study, a result supported by Parolin (2000), who found similar results for other tree species.

In all species in the shade leaveswas observed high values of WUEduring the terrestrial wet phase. Moreover,in Amoioua guianensisa distinctly higher WUE was observed comparing to the other three studied species. The WUE varies among species within the same environment (Kramer and Boyer, 1995).

\subsubsection{Diumal reduction of photosynthetic activity}

Tropical trees often experience midday and post midday reduction of net photosynthesiscaused by water stress (Williams et al. 1998). High temperature ranges from $35-45^{\circ} \mathrm{C}$ also tend to hinder photosynthetic rate (Barry and Björkman 1980). Direct solar radiation in the tropics often increases midday leaf temperatures to $40^{\circ} \mathrm{C}$ and more (Koch et al. 1994).

In sun- exposed leaves we recorded temperature ranges from $32.5^{\circ} \mathrm{Cto} 39.7^{\circ} \mathrm{C}$ (average values in Tab. 2).We have observed that the turgor of the leaves sank and they wilted. This was clear sign of water tress. Doughty and Golden (2008) and Lewis et al.(2004) reported that the temperatures of leaves at the top of the canopy around midday may reach inflectionpoint,and the enzymes and membranes lose functionality.

We found a negative correlation of leaf temperature and photosynthetic activityinAmoioua guianensisbut not inPiranhea trifoliata.The effect of rising temperatures on photosynthesis via stomatal closure is the dominant negative impact on tropical forests (Lloyd\& Farquhar 2008). The low stomatal conductance and intercellular $\mathrm{CO}_{2}$ concentration was observed 
specifically during the terrestrial dry phase inAmoioua guianensis in the sun and shade leaves (Tab. 1). Dense tree canopy formsa microclimate with lower leaf temperatures. The leaves in the tree canopy are effectively adapted to the lower availability of sun radiation and PAR. 
Table 2: Diurnal gas exchange properties in sun and shade leaves of four tree species in the Araguaia floodplain forest. A different letter behind the means indicate statistical difference between photosynthetic properties $(\mathrm{p}<0.05)$.

\begin{tabular}{|c|c|c|c|c|c|c|}
\hline Part of day & $\begin{array}{l}\text { Leaf temp. } \\
\left({ }^{\circ} \mathrm{C}\right)\end{array}$ & $\begin{array}{c}\text { Sub-stomatal } \\
\mathrm{CO}_{2} \\
(\mathrm{ppmv})\end{array}$ & $\begin{array}{c}\text { Transpiration } \\
\text { rate } \\
\left(\mathrm{mmol} \mathrm{m}^{-2} \mathrm{~s}^{-1}\right)\end{array}$ & $\begin{array}{c}\text { Stomatal } \\
\text { conductance } \\
\text { of } \mathrm{CO}_{2} \\
\left(\mathrm{mmol} \mathrm{m}^{-2} \mathrm{~s}^{-1}\right)\end{array}$ & $\begin{array}{c}\text { Net } \\
\text { Photosynthetic } \\
\text { rate } \\
\left(\mu \mathrm{mol} \mathrm{m}^{-2} \mathrm{~s}^{-1}\right)\end{array}$ & $\begin{array}{l}\text { Water use } \\
\text { eficiency }\end{array}$ \\
\hline \multicolumn{7}{|c|}{ Amoiouaguianensis (sun) } \\
\hline morning & $35.4 \pm 1.2 \mathrm{a}$ & $190 \pm 13$ a & $3.44 \pm 0.39 a$ & $145 \pm 25$ a & $10.05 \pm 0.63 \mathrm{a}$ & 0.0029 \\
\hline noon & $35.9 \pm 0.6 \mathrm{a}$ & $208 \pm 9 a$ & $4.41 \pm 0.32 \mathrm{a}$ & $166 \pm 15$ a & $10.45 \pm 0.49$ a & 0.0024 \\
\hline afternoon & $37.6 \pm 0.6 \mathrm{a}$ & $180 \pm 12$ a & $4.04 \pm 0.55 \mathrm{a}$ & $110 \pm 13 a$ & $9.66 \pm 1.15 \mathrm{a}$ & 0.0024 \\
\hline \multicolumn{7}{|c|}{ Piranhea trifoliata (sun) } \\
\hline morning & $36.2 \pm 0.6 \mathrm{a}$ & $198 \pm 5$ a & $6.28 \pm 0.41 \mathrm{a}$ & $254 \pm 8 \mathrm{a}$ & $15.85 \pm 0.48 a$ & 0.0025 \\
\hline noon & $37.9 \pm 0.7 \mathrm{a}$ & $193 \pm 20 \mathrm{a}$ & $4.69 \pm 0.70 \mathrm{a}$ & $141 \pm 21 b$ & $9.97 \pm 1.40 \mathrm{~b}$ & 0.0021 \\
\hline afternoon & $36.8 \pm 0.2 \mathrm{a}$ & $197 \pm 7 \mathrm{a}$ & $4.88 \pm 0.37 \mathrm{a}$ & $156 \pm 15 \mathrm{~b}$ & $10.78 \pm 0.81 \mathrm{~b}$ & 0.0022 \\
\hline \multicolumn{7}{|c|}{ Amoiouaguianensis (shade) } \\
\hline morning & $32.0 \pm 1.2 \mathrm{a}$ & $245 \pm 13$ a & $2.91 \pm 0.33 \mathrm{a}$ & $142 \pm 11$ a & $6.87 \pm 0.76 \mathrm{a}$ & 0.0024 \\
\hline noon & $32.11 .4 \mathrm{a}$ & $216 \pm 16$ a & $1.97 \pm 0.28 \mathrm{a}$ & $95 \pm 8 \mathrm{~b}$ & $6.71 \pm 0.71 \mathrm{a}$ & 0.0034 \\
\hline afternoon & $31.8 \pm 1.1 \mathrm{a}$ & $244 \pm 14$ a & $2.55 \pm 0.30 \mathrm{a}$ & $133 \pm 11 a b$ & $6.52 \pm 0.87 a$ & 0.0026 \\
\hline \multicolumn{7}{|c|}{ Nectandrarigida (shade) } \\
\hline morning & $34.0 \pm 0.6 \mathrm{a}$ & $250 \pm 19$ a & $2.87 \pm 0.19 \mathrm{a}$ & $118 \pm 13$ a & $5.33 \pm 0.57 \mathrm{a}$ & 0.0019 \\
\hline noon & $34.3 \pm 0.5 \mathrm{a}$ & $263 \pm 18$ a & $3.45 \pm 0.31 \mathrm{a}$ & $135 \pm 12$ a & $4.64 \pm 0.43 a$ & 0.0013 \\
\hline afternoon & $31.8 \pm 0.1 \mathrm{a}$ & $229 \pm 14$ a & $2.39 \pm 0.17 \mathrm{a}$ & $112 \pm 13$ a & $6.92 \pm 0.25 \mathrm{a}$ & 0.0029 \\
\hline \multicolumn{7}{|c|}{ Piranhea trifoliata (shade) } \\
\hline morning & $33.9 \pm 8$ a & $231 \pm 13$ a & $2.90 \pm 0.26 \mathrm{a}$ & $123 \pm 13 a$ & $7.21 \pm 0.66 \mathrm{a}$ & 0.0025 \\
\hline noon & $35.2 \pm 1.2 \mathrm{a}$ & $231 \pm 9 a$ & $2.68 \pm 0.27 \mathrm{a}$ & $98 \pm 12 \mathrm{a}$ & $5.96 \pm 0.61 \mathrm{a}$ & 0.0022 \\
\hline afternoon & $33.7 \pm 0.6 \mathrm{a}$ & $227 \pm 19$ a & $2.83 \pm 0.30 \mathrm{a}$ & $121 \pm 13$ a & $6.84 \pm 0.60 \mathrm{a}$ & 0.0024 \\
\hline \multicolumn{7}{|c|}{ Vochysiadivergens (shade) } \\
\hline morning & $33.8 \pm 0.6 \mathrm{a}$ & $244 \pm 9 a$ & $4.13 \pm 0.25 \mathrm{a}$ & $183 \pm 7$ a & $8.59 \pm 0.70 \mathrm{a}$ & 0.0021 \\
\hline noon & $34.4 \pm 0.5 \mathrm{a}$ & $254 \pm 13$ a & $3.33 \pm 0.30 \mathrm{a}$ & $125 \pm 12 b$ & $6.17 \pm 0.82 \mathrm{a}$ & 0.0019 \\
\hline afternoon & $34.5 \pm 0.5 \mathrm{a}$ & $247 \pm 7$ a & $3.65 \pm 0.21 \mathrm{a}$ & $144 \pm 9 \mathrm{~b}$ & $7.24 \pm 0.55 \mathrm{a}$ & 0.0020 \\
\hline
\end{tabular}




\subsection{Conclusion}

High inter-annual variations ofenvironmental conditions in the region of the Araguaia floodplain influence the photosynthetic activity of the trees. The occurrence of flood, soil water saturation, and reduction of sun radiation caused by increased cloudiness are defining factors of the aquatic period. Our observations confirmed that the reduction of photosynthetic activity during the aquatic phase was caused by soil water saturation, and reduction of solarradiation caused by cloudiness.

The terrestrial dry phase was characterized as nearly 3- months without any precipitation,high radiation and leaf temperaturesrangingfrom 35 to $45^{\circ} \mathrm{C}$. During the dry period, decreases of photosynthetic activity were observed, but they were less pronounced than in the aquatic phase. The closures of stomata were not as a defense against a high transpiration rate or prevention of excessive water-loss. Observed high groundwater level and high soil moisture advised that trees were capable of utilizing soilwater during dry seasons in order to avoid drought stress.

The terrestrial wet phase was the period when the highest photosynthetic rates were measured.

The observed midday decreases in photosynthetic activity were the effect of the stressed water status of the leaves.

The phenology of some tree species showedadaptations to the seasonal changes: leaves senescence during the aquatic phase in Piranhea trifoliataand pronounced leaf fall during terrestrial dry phase inVochysia divergens. 


\section{References}

Adis J., Furch K. and Irmler U., 1979. Litter production of a Central Amazonian black water inundation forest. Tropical Ecology 20:236-245.

Armbrüster N, Müller E, Parolin P.,2004. Contrasting responses of two Amazonian floodplain trees to hydrological changes.Ecotropica.;10:73-84.

Ayres, J.M., 1993. As Matas de Várzea do Mamirauá. Estudos de Mamirauá, vol. 1.Sociedade Civil Mamirauá, MCT-CNPq, Rio de Janeiro

Berry, J A. and Björkman, O., 1980. Photosynthetic response and adaptation to temperature in higher plants.Annu. Rev. Plant Physiol. 31, 491-453

Boisier, J. P., Ciais, P., Ducharne, A., and Guimberteau, M. 2015: Projected strengthening of Amazonian dry season by constrained climate model simulations, Nature Climate Change, 5, 656-660, doi: 10.1038/nclimate2658.

Borma, L. S.,da Rocha, H. R.,CabralO. M., von Randow,C.,Collicchio,E., Kurzatkowski,D., BruggerP. J.,FreitasH.,Tannus, R.,Oliveira,L., Renno,C. D., Artaxo, P. 2009, Atmospheric and hydrological controls of the evapotranspiration over a floodplain forest in the Bananal Island region, Amazonia, J. Geophys. Res.,

Brando, P. M., Goetz, S. J., Baccini, A., Nepstad, D. C., Beck, P. S. A., and Christman, M. C. 2010: Seasonal and interannual variability of climate and vegetation indices across the Amazon, P. Natl. Acad. Sci. USA, 107, 14685-14690,

Buschmann C, Grumbach K. Physiologie der Photosynthese. Berlin: Springer Verlag; 1985. Chaves MM, Maroco JP, Pereira JS. Understanding plant responses to drought - from genes to the whole plant.Functional Plant Biology. 2003;30:239-264.

Chauvel, A., A. R. T. Vital, Y. Lucas, T. Desjardins, W. K. Franklen, F. J. Luizõo, L. A. Araguás, K. Rozanski, and A. P. Bedmar (1992), The Role of Roots Over the Forest Hydrological Cycle, (in Portuguese), pp. 298-302, VII Brasilian Congress on Meteorology, São Paulo, Brazil. 
Cleveland, C. C., Taylor, P., Chadwick, K. D., Dahlin, K., Doughty, C. E., Malhi, Y., Smith, W. K., Sullivan, B. W., Wieder, W. R., and Townsend, A. R. 2015: A comparison of plotbased satellite and earth system model estimates of tropical forest net primary production, Global Biogeochem. Cy., 29, 626-644, doi: 10.1002/2014GB005022.

da Rocha, H.R.; Goulden, M.L.; Miller, S.D.; Menton, M.C.; Pinto, L.D.V.O; Freitas, H.C; et al. 2004. Seasonality of water and heat fluxes over a tropical forest in eastern Amazonia. Ecological Applications, 14: 22-32.

da Rocha, H.R.; Manzi, A.O.; Cabral, O.M.; Miller, S.D.; Goulden, M.L.; Saleska, S.R.; et al. 2009. Patterns of water and heat flux across a biome gradient from tropical forest to savanna in Brazil. Journal of Geophysical Research, 114: 1-8.

Departamento Nacional de Produção Mineral (DNPM), 1978. Projecto RADAMBRASIL. FolhaSC. 20 Porto Velho; geologia, geomorfologia, pedologia, vegetação e uso potencial da terra. Anexo: Analiseestistitica de dados (Vegetacão). Departamento Nacional de Produção Mineral, Rio de Janeiro, Brazil.

Doughty, C., Goulden, M., L., 2008: Are tropical forests near a high temperature threshold? Journal of Geophysical Research Vol. 113.

Farquhar G. D. 1979: Models describing the kinetics of ribulose biphosphate carboxylaseoxygenase. Auch.Biochem.Biophys. 193, 456-468.

Farquhar, G., Sharkey, T., D. 1982: Stomatal conductance and Photosynthesis. Annual Review of Plant Physiology p.318 -340.

Fernandez M., D. 2006: Changes in photosynthesis and fluorescence in response to flooding in emerged and submerged leaves of Pouteriaorinocoensis. Photosynthetica 3-2006, Volume 44, Issue 1, pp 32-38.

Fernandez M., D., Pieters, A., Danoso, C., Herrera, C., Tezara, W., Rengifo, E., Herrera, A. 1999. Seasonal changes in photosynthesis of trees in the flooded forest of Mapire river. Tree Physiol. 19: 79-85, 1999 
Field, J. G., Clarke, K. R., Warwick, R. M. (1982). A practical strategy for analyzing multispecies distribution patterns. Mar. Ecol. Prog. Ser. 8: 37-52

Franken, M., Irmler U. and Klinge, H. 1979: Litterfall in inundation, riverine and terra firme forests of Central Amazonia. Tropical Ecology 20:225-235.

Gatti, L. V., Gloor, M., Miller, J. B., Doughty, C. E., Malhi, Y., Domingues, L. G., Basso, L. S., Martinewski, A., Correia, C. S. C., Borges, V. F., Freitas, S., Braz, R., Anderson, L. O., Rocha, H., Grace, J., Phillips, O. L., and Lloyd, J. 2014.: Drought sensitivity of Amazonian carbon balance revealed by atmospheric measurements, Nature, 506, 76-80,

Giorio,P.,Sorrentino,G.,D’Andria,R.,1999.Stomatal behaviour, leaf water status and photosynthetic respons ein field-grown olive trees under water deficit. Environ. Exp. Bot. 42, 95-104.

Gottsberger, G. 1978. Seed dispersal by fish in the inundated regions of Humaitá, Amazonia.Biotropica 10(3):170-183.

Goulding, M. 1980. The fishes and the forest. Explorations in Amazonian natural history Univ. of California Press

Hall AE, Schulze E-D (1980) Drought effects on transpiration and leaf water status of cowpea in controlled environments. Aust. J. Plant Physiol. 7: 141 - 147.

Heute, A. R., Didan K., Shimabukuro, Y. E., Ratana, P., Saleska S. R., Hutyna L. R., Yang W.Z, Nemani, R. R., Myneni, 2006: Amazon rainforest green-up with sunlight in dry season, Geophys. Res. Lett., 33 (6) , L06405.

Jipp, P. H., D. C. Nepstad, D. K. Cassel, and C. R. de Carvalho1998, Deep soil moisture storage and transpiration in forests and pastures of seasonally-dry Amazonia, Clim. Change, 39, 395-412.

Junk, W. J. 1989: Flood tolerance and tree distribution in Central Amazonian floodplains. Pp. 47-64 in Nielsen, L. B., Nielsen, I. C. \& Baisley, H. (eds). Tropical forests: botanical dynamics, speciation and diversity. Academic Press, London. 
Keppel-Aleks, G., Wolf, A. S., Mu, M., Doney, S. C., Morton, D. C., Kasibhatla, P. S., Miller, J. B., 25 Dlugokencky, E. J., and Randerson, J. T. 2014: Separating the influence of temperature, drought,and fire on interannual variability in atmospheric CO2, Global Biogeochem. Сy., 28, 1295-1310,

Kitajima, K. 1994. Relative importance of photosynthetic traits and allocation patterns as correlates of seedling shade tolerance of 13 tropical trees. Oecologia 98:419-428.

Koch, G, W., J. S. Amthor, and M.L. Goulden 1994: Diurnal paterns of leaf photosynthesis, conductance and water potencial at the top of a lowland rain-forest canopy in CameroonMeasurements from the Radeau-Des-Cimes. Tree Physiol., 14 (4), 347-360.

Kozlowski, T.T. 1984. Responses of woody plants to flooding.In Flooding and Plant Growth.Ed. T.T. Kozlowski. Academic Press, New York, pp 129-163.

Kurzatkowski, D., Leuchner, Ch., Homeier, J., 2015: Effects of flooding on trees in the semi-deciduous transition forests of the Araguaia floodplain, Brazil. ActaOecologica 69, Pages 21-30.

Kramer P. J., Boyer J. S. 1995: Water relations If plant and soils. San Diego Academic press.

Larcher, W. 1995. Physiological Plant Ecology, Third Edn. Berlin:Springer.

Larcher W (2003) Physiological plant ecology. Ecophysiology and stress physiology of functional groups. Springer, Berlin, Heidelberg, New York

Long, S.P., Zhu, X.G., Naidu, S.L.\&Ort, D.R.2006. Can improvement in photosynthesis increase crop yields?Plant, Cell and Environment29: 315-330.

Lopez, O., R., and Kursar, T., A.: 1999: Flood tolerance of four tropical tree species Tree Physiol 19(14): 925-932 
Lloyd, J.; Farquhar, G.D. 2008.Effects of rising temperatures and $\left[\mathrm{CO}_{2}\right]$ on the physiology of tropical forest trees. Philosophical Transactions of the Royal Society B: Biological Sciences, 363: 1811-1817.

Lewis, S.L., Malhi, Y. \& Phillips, O.L. (2004) Fingerprinting the impacts of global change on tropical forests.Philosophical Transactions of the Royal Society, Series B, 359, 437-462. Lüttge, Ulrich. 'Tropical Forests.II. Ecophysiological Responses to Light."Physiological Ecology of Tropical Plants (2008): 103-148.

Maia L., M., A. 1997: Influencia do pulso de inundacaonafisiologia, fenologia e producao de frutos de Heveaspruceana(Euphorbiaceae) e Eschweileratenuifolia(Lecythidaceae), em area inundavel de igapo da Amazonia Central. Ph.D. thesis, INPA/FUA Manaus.195 pp.

Maia LA, Piedade MTF.. 2002 Influence of the flood pulse on leaf phenology and photosynthetic activity of trees in a flooded forest in Central Amazonia/Brazil. Amazoniana;17:53-63.

Malhi, Y., A. D. Nobre, J. Grace, B. Kruijt, M. G. P. Pereira,A. Culf, and S. Scott. 1998. Carbon dioxide transfer overa central Amazonian rain forest. Journal of Geophysical Research D24:31593-31612

Manheimer, S.; Bevilaqua, G; Caramaschi, E.P.,Scarano, F.R. 2003.Evidence for seed dispersal by the catfish Auchenipterichthyslongimanus in an Amazonian lake.Journal of Tropical Ecology 19:215-218.

Martins, A. \&Kardec, E., 2006. Relações solo-geoambienteem áreas de ocorrências de Ipucas na planície do MédioAraguaia - Estado de Tocantins.Rev. Árvore [online].2006, vol.30, n.2, pp. 297-310.ISSN 0100-6762.

Moegenburg, S. M. 2002. Spatial and temporal variation in hydrochory in Amazonian floodplain forest.Biotropica 34:606-612.

Medina, E. 1984.Nutrient balance and physiological processes at the leaf level. Pp.134-154 in: Physiological Ecology of Plants of the Wet Tropics. 
Meyer U. 1991: Feinwurzelsysteme und Mykorrhizatypen als Anpassungsmechanismen in zentralamazonischen Überschwemmungswaäldern, igapo und varzea. Ph.D. thesis, University of Hohenheim.

Mielke, M., S., Almeida, A., A., F., Gomes F., P., Aguilar, M., A., Mongabeira, P., A., 2003 Leaf gas exchange, chlorophyll fluorescence and growth responses of Genipaamericana seedlings to soil flooding. Environmental and Experimental Botany, Vol. 50, Issue 3, p. 221231.

Mooney, H.A., S.L. Gulmon and N.D. Johnson. 1983. Physiological constraints on plant chemical defenses. In Plant Resistance to Insects. Ed. P.A. Hedin. Amer. Chem. Sot. Symp.No. 208. Amer. Chem. Sot., Washington, D.C. pp 21-34.

Nepstad, D. C. 1989. Forest regrowth on abandoned pastures in eastern Amazonia: Limitations to tree seedling survival and growth, Ph.D. thesis, Yale Univ. Press, New Haven, Conn

Nepstad, D. C., Carvalho, C. R.d., Davidson, E. A., Jipp, P. H., Lefebvre, P.A, Negreiros G. H, Silva, E.D.d, Stone, T.A. Trumbore, S.E., Vieira. S. 1994: The role of deep roots in the hydriological and carbon cycles of Amazonian forest and pastures, Nature, 372, 666-669.

Nogueira, A., Martinez, C., A., Ferreira, L., L., Prado, C., H., B., A.: 2004: Photosynthesis and Water Use Efficiency in Twenty Tropical Tree Species of Differing Succession Status in a Brazilian Reforestation. Photosynthetica 2004, Vol. 42, Issue 3, pp 351-356

Parolin P. 1997: Auswirkungen periodischer Vernässung und Überflutung auf Phänologie, Photosynthese und Blattphysiologie von Baumarten unterschiedlicher Wachstumsstrategie in zentralamazonischen Überschemmungsgebieten.Herbert UtzVerlag, München. 166 pp.

Parolin, P. 1999. Growth strategies of Senna reticulate andCecropialatiloba, two pioneer tree species of Central Amazonian floodplains. BielefelderÖkologischesBeitrege14: 272277.

Parolin, P. 2000: Phenology and $\mathrm{CO}_{2}$-assimilation of trees in Central Amazonian floodplains. Journal of Tropical Ecology16: 465-473. 
Parolin, P. 2001: Morphological and physiological adjustments to waterlogging and drought in seedlings of Amazonian floodplain trees. Oecologia, Vol. 128, Issue 3, pp 326-335

Parolin, P.; Armbruester, N.; Wittmann F.; Ferreira, L.V.; Piedade, M.T.F \& Junk, W.J. 2002. A review of tree phenology in central Amazonian floodplains.Pesquisas, Botânica 52: 195-222.

Parolin, P., Lucas, C., Piedade, M. T. F., \&Wittmann, F. 2010.Drought responses of floodtolerant trees in Amazonian floodplains. Annals of Botany, 105(1), 129-139.

Piedade, M.T.F., Junk W.J. and Parolin P. 2000: The flood pulse and photosynthetic response of trees in a white water floodplain (varzea) of the Central Amazon. Brasil.Verhandlungen des Internationalen Vereines für Limnologie27: 1-6

Poulter, B., Frank, D., Ciais, P., Myneni, R. B., Andela, N., Bi, J., Broquet, G., Canadell, J. G., Chevallier, F., Liu, Y. Y., Running, S. W., Sitch, S., and van der Werf, G. R. 2014: Contribution of semi-arid ecosystems to interannual variability of the global carbon cycle, Nature, 509, 600-603.

Prado, C.H.B.A., Wenhui, Z., Rojas, M.H.C., Souza, G.M., 2004. Seasonal leaf gas exchange and water potential in a woody cerrado species community. Braz. J.Plant Physiol. 16(1), 7-16

Ramos, J., \& Grace, J., 1990.The Effects of Shade on the Gas Exchange of Seedlings of Four Tropical Trees from Mexico.Functional Ecology,4(5), 667-677.

Rengifo, E., Tezara, W., Herrera A. 2005. Water relations, chlorophyll $a$ fluorescence, and contents of saccharides in tree species of a tropical forest in response to flood Journal. Photosynthetica, Vol. 43, Issue 2, pp 203-210.

Restrepo-Coupe, N., da Rocha, H. R., Hutyra, L. R., da Araujo, A. C., Borma, L. S., Christoffersen, B., Cabral, O. M. R., de Camargo, P. B., Cardoso, F. L., da Costa, A. C. L., Fitzjarrald, D. R., Goulden, M. L., Kruijt, B., Maia, J. M. F., Malhi, Y. S., Manzi, A. O., Miller, S. D., Nobre, A. D., von Randow, C., Sá, L. D. A., Sakai, R. K., Tota, J., Wofsy, S. C., Zanchi, F. B. and Saleska, S. R. 2013: What drives the seasonality of photosynthesis 
across the Amazon basin? A cross-site analysis of eddy flux tower measurements from the brasil flux network, Agr. Forest Meteorol, 182-183, 128-144.

Sage, R. F. and Kubien, D. S. 2007.The temperature response of $C_{3}$ and $C_{4}$ photosynthesis. Plant, Cell \& Environment, 30: 1086-1106.

Schimel, D., Pavlick, R., Fisher, J. B., Asner, G. P., Saatchi, S., Townsend, P., Miller, C., Frankenberg, C., Hibbard, K., and Cox, P. 2015: Observing terrestrial ecosystems and the carbon cycle from space, Glob. Change Biol., 21, 1762-1776

Schlüter U. B. 1989. Morphologische, anatomische und physiologische Untersuchungen zur Überflutungs toleranz zweier charakteristischer Baumarten (Astrocaryum jauari und Macrolobium acaciaefolium) des Weiß- und Schwarzwasser überschwemmungswaldes bei Manaus. - Ein Beitrag zur Ökosystemanalyse von varzea und igapo

Zentralamazoniens.Ph.D. thesis.University of Kiel.147 pp.

Schlüter U.B. and Furch, B., 1992.Morphologische, anatomische und physiologische Untersuchungen zur Überflutungstoleranz des Baumes Macrolobium acaciaefolium, charakteristisch für die Weiß- und Schwarzwasseruüberschwemmungswälder bei Manaus, Amazonas. Amazoniana12:51-69.

Schöngart, M.T.F. Piedade, S. Ludwigshausen, V. Horna, M. Worbes:2002, Phenology and stem growth periodicity of tree species in Amazonian floodplain forestsJ. Trop. Ecol, 18 pp. $581-597$

TaizZeiher, 1991.The Physiology of Plants Under Stress: Soil and Biotic Factors, Band 2 Thompson WA, Kriedemann PE, Craig IE. 1992.Photosynthetic Response to Light and Nutrients in Sun-Tolerant and Shade-Tolerant Rainforest Trees. I. Growth, Leaf Anatomy and Nutrient Content.Australian Journal of Plant Physiology19 , 1-18.

Waldhoff D., Junk W. J. and Furch, B. 1998. Responses of three Central Amazonian tree species to drought and flooding under controlled conditions. International Journal of Ecology and Environmental Sciences 24:237-252. 
Williams, M., Y. Malhi, A. Nobre, E.B. Rastetter, J. Grace and M.G.P. Pereira. 1998. Seasonal variation in net carbon exchange and evapotranspiration in a Brazilian rain forest: a modelling analysis. Plant Cell Environ. 21:953-968.

Wittmann F. and Parolin P. 1999. Phenology of six tree species from Central Amazonian varzea. Ecotropica5:51-57.

Worbes, M. 1985. Structural and other adaptations to longterm flooding by trees in Central Amazonia.Amazoniana 9:459-484.

Worbes, M. 1986. Lebensbedingungen und Holzwachstum in zentralamazonischen Überschwemmungswäldern. Scripta Geobotanica 17, Lehrstuhl für Geobotanik der Universität Göttingen. 83 pp.

Worbes M. 1997.The forest ecosystem of the floodplains. Pp. 223-266 in Junk, W. J. (ed.). The Central Amazon floodplains.Ecology of a pulsing system. Springer Verlag, Berlin. von Caemmerer, S.\&Evans, J.R.2010. Enhancing C 3 photosynthesis.Plant Physiology154: 589-592.

Zhang, Y., Guanter, L., Berry, J. A., Joiner, J., van der Tol, C., Huete, A., Gitelson, A., Voigt, M., and Köhler, P. 2014: Estimation of vegetation photosynthetic capacity from space-based measurements of chlorophyll fluorescence for terrestrial biosphere models, Glob. Change Biol., 20, 3727-3742,

Ziburski, A. 1991. Dissemination, Keimung und Etablierung einiger Baumarten der Überschwemmungswäder Amazoniens. Tropische und subtropische Pflanzenwelt77:1-96. 
Chapter 5

\section{General conclusions of the research}




\section{General conclusions of the research}

In this study, we found high inter-annual variation in flood levels in the Araguaia floodplain, but flood duration is on average two times shorter and flood level is four times lower than in typical várzea or igapóforests of the Central Amazon. A further difference with these forests is the occurrence of a pronounced dry period of three months.

Although there was no significant effect of flooding on tree diversity, tree species composition and family importance values differed markedly between AF and NAF. This shows that habitat colonization by trees in the Araguaia floodplain is strongly linked to resistance and adaptation to flooding. The influence of flooding as a driver of forest structure was manifested by its negative influence on canopy height and by a positive correlation with WSG of the recorded tree species.

Family composition is similar to Central Amazonian floodplain forests, and many widely distributed flood-tolerant tree species are shared. The significantly lower AGB is probably a result of the lower soil fertility combined with the pronounced dry season in the Araguaia floodplain.

Our forest dynamics data show that aboveground biomass and productivity are relatively low compared to central Amazonian várzea floodplain forests. In contrast to other Amazonian igapó and várzea floodplains, the flooding gradient imprinted only weakly on most stand-level structural and dynamic properties, while it influenced mean wood density and maximum stand height. As expected, tree mortality rates were relatively high in both annually and non-annually flooded plots, probably due to different causes. The high mortality observed in large NAF plot trees is likely a consequence of ENSO-related droughts which may threaten seasonally-dry floodplain forests at the edge of the Amazon more than in the humid regions of central Amazonia.

Contrary to our expectation, we found no decrease in recruitment rate from low to high terrain, suggesting that flooding is only one factor controlling tree regeneration in these floodplain forests. 
High inter-annual variations of environmental conditions in the region of the Araguaia floodplain influence the photosynthetic activity of the trees. The occurrence of flood, soil water saturation, and reduction of sun radiation caused by increased cloudiness are defining factors of the aquatic period.

The terrestrial dry phase was characterized by almostthree months without any precipitation, high radiation and leaf temperaturesranging from 35 to $45^{\circ} \mathrm{C}$. During the dry period, decreases of photosynthetic activity were observed, but they were less pronounced than in the aquatic phase. Observed high groundwater level and high soil moisture advised that trees were capable of utilizing soilwater during dry seasons in order to avoid drought stress. The terrestrial wet phase was the period when the highest photosynthetic rates were measured. The observed midday decreases in photosynthetic activity were the effect of the stressed water status of the leaves.

The phenology of some tree species showed adaptations to the seasonal changes: leaves senescenceoccurred during the aquatic phase in Piranhea trifoliataand we observed pronounced leaf fall during terrestrial dry phase in Vochysia divergens.

We conclude that the floodplain forests of Araguaia are unique forest ecosystems, which are threatened by transformation in many places. When intact, they still seem to function as a net carbon sink, but this may change with increasing severity of climate warming-related droughts. In view of the predicted increase of extended drought periods, we assume that future forests in the study area most likely will lose those tree species that are not droughttolerant enough, and as a further consequence, AGB will decline as the growth limitation increases. 


\section{Acknowledgments}

I would like to thank PD. Dr. Martin Worbes who accepted me into $\mathrm{PhD}$ program and supervised me in the first phase of my study.

I am also grateful to Prof. Christoph Leuchner for giving me the opportunity to finish my $\mathrm{PhD}$ at the department of Plant Ecology and Ecosystem Research, and for his supervisionby writing the thesis and publishing the papers.

Special thanks go to Jürgen Homeier, for very helpful advice and discussions during work with the data and writing the papers.

I thank my wife Giovana for support me throughout the time of my studies.

A lot of people supported me during the project in Brazil. Of this group of people I want thank Dr. Divaldo Rezende, Stefano Merlin, Prof. Dr. Humberto da Rocha, Prof. Dr. Laura Borma, Prof. Dr. Erick Colicchio and Dr. Christopher Martius. For support in the field work

specially thanks to Florian Alexander Geipel, Rita da Mata Ribeiro, Soraya Rodrigues da Silva, and many students from the University of Palmas and volunteers from the Instituto Ecológica.

I thank the Instituto Ecológica and the University of Palmas in Brazil for their continued support and access to their research facilities.

I am also grateful to Brazilian National Council for Scientific and Technological Development (CNPq) for the financial support during the fieldwork in Brazil and the Catholic Academic Exchange Service (KAAD) for the scholarship during a three- year period in Göttingen. 


\section{Curriculum vitae}

\section{Dariusz Kurzątkowski}

\section{PERSONAL DATA}

Date of birth $\quad 15$ July 1970

Place of birth Warsaw

Citizenship Polish

kurzatkowski@hotmail.com

\section{EDUCATION}

1990-1995 Academy of Agronomy, Szczecin, Poland; Engineer and Master Degree in Horticulture

1995-1999 University of Göttingen; Faculty of Agricultural Sciences, Master of Science in the Tropics and Subtropics

2008-2017 University of Göttingen, Ph.D, International Program for Agricultural Sciences in Göttingen (IPAG) 